III) Nordic Council of Ministers

Nordic Countries Overview of Work with Perpetrators of Intimate Partner Violence 



\section{Nordic Countries Overview of Work with Perpetrators of Intimate Partner Violence}

Berta Vall

Project Coordinator

PhD in Psychology

TemaNord 2017:513 


\section{Nordic Countries Overview of Work with Perpetrators of Intimate Partner Violence}

Berta Vall, Project Coordinator. PhD in Psychology.

ISBN 978-92-893-4902-4 (PRINT)

ISBN 978-92-893-4903-1 (PDF)

ISBN 978-92-893-4904-8 (EPUB)

http://dx.doi.org/10.6027/TN2017-513

TemaNord 2017:513

ISSN $0908-6692$

Standard: PDF/UA-1

ISO $14289-1$

(c) Nordic Council of Ministers 2017

Layout: NMR

Print: Rosendahls

Printed in Denmark

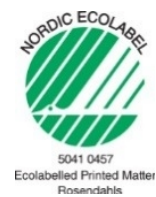

Although the Nordic Council of Ministers funded this publication, the contents do not necessarily reflect its views, policies or recommendations.

\section{Nordic co-operation}

Nordic co-operation is one of the world's most extensive forms of regional collaboration, involving Denmark, Finland, Iceland, Norway, Sweden, the Faroe Islands, Greenland, and Åland.

Nordic co-operation has firm traditions in politics, the economy, and culture. It plays an important role in European and international collaboration, and aims at creating a strong Nordic community in a strong Europe.

Nordic co-operation seeks to safeguard Nordic and regional interests and principles in the global community. Shared Nordic values help the region solidify its position as one of the world's most innovative and competitive. 


\section{Contents}

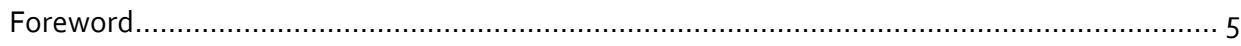

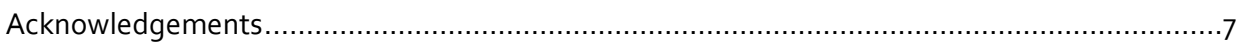

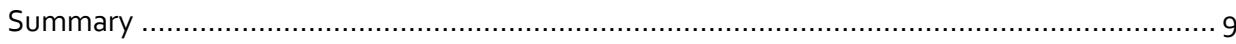

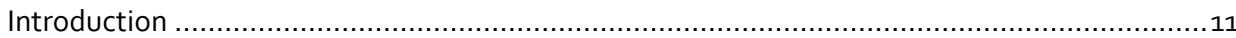

Perpetrators programmes in Europe: best practices and minimum standards ..................11

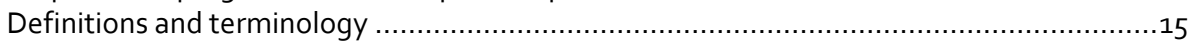

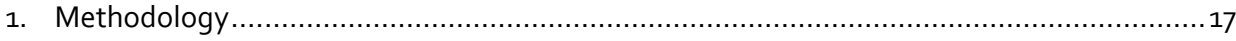

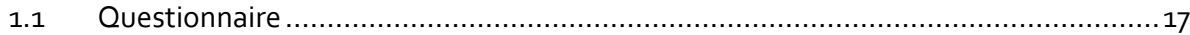

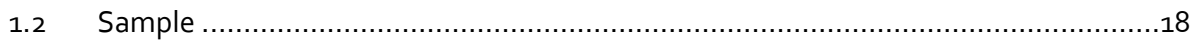

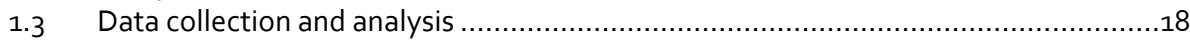

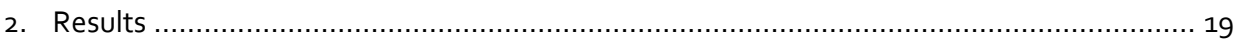

2.1 Section A: basic information ................................................................... 19

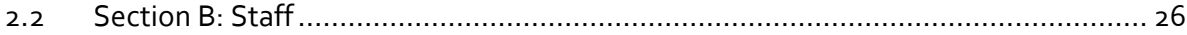

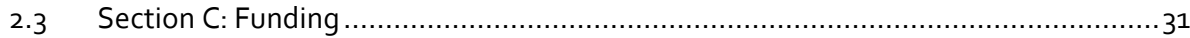

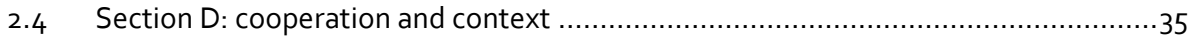

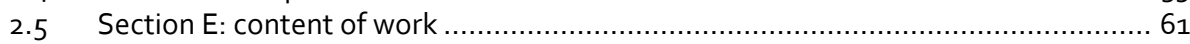

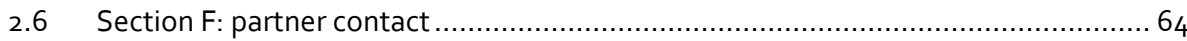

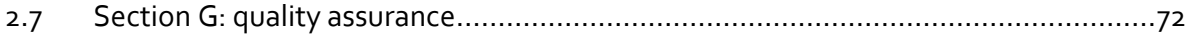

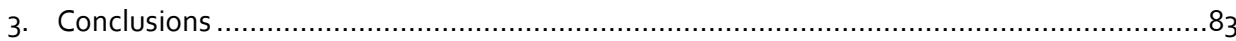

3.1 Basic Information and characteristics of the programmes (location, staff, and

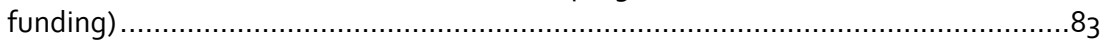

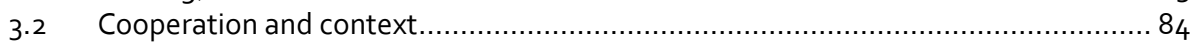

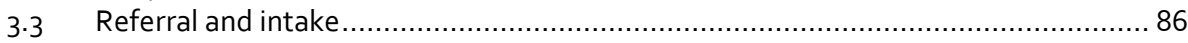

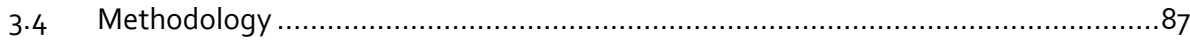

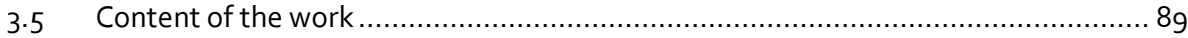

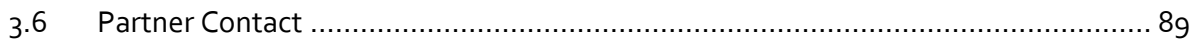

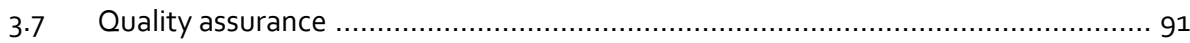

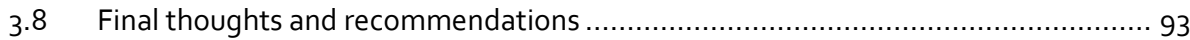

3.9 Limitations of the study and recommendations for future research .....................97

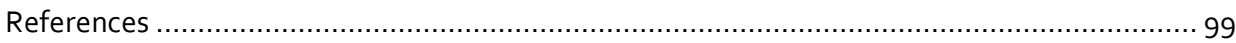

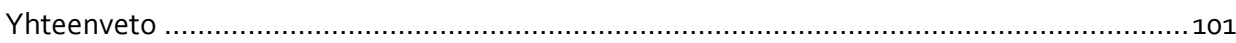

Nu Räcker Det - Katsaus parisuhdeväkivallan tekijöiden kanssa tehtävään työhön eri

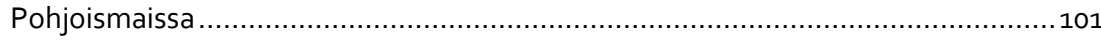

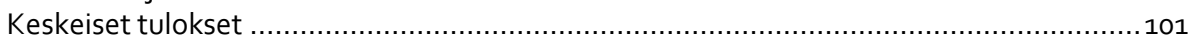

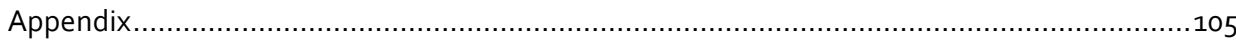

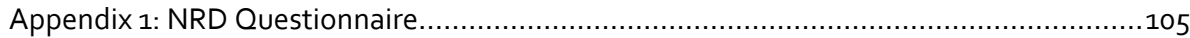





\section{Foreword}

Gender-related violence is a major problem in the Nordic countries. As a response, the Nordic co-operation programme on gender equality 2015-2018 has adopted work against violence as its focus area. The ultimate goal for preventing gendered violence is to stop it from happening in the first place. An integral part of domestic (DV) and intimate partner violence (IPV) prevention is reducing its occurrence by promoting nonviolent behavior and healthy relationships.

During the Finnish presidency in 2016, the Nordic Council of Ministers initiated a project to to map out the different services available in the Nordic countries for perpetrators of DV or IPV. The project was titled "Nu Räcker Det"! Nordiska modeller för att få slut på våld i nära relationer, (meaning [It's] Enough Now! Nordic models to end violence in close relationships). The purpose of the project was to canvass the different practices and methods developed and used across the Nordic countries aiming to end violent behavior in close relationships. The project was carried out by The Finnish National Institute for Health and Welfare.

There are various types of perpetrator treatment programmes currently implemented in Europe. In the Nordic countries, these services have been available for a few decades. However, no comprehensive data or information was available to allow comparisons between methodology and different approaches in the Nordic countries.

The "Nu Räcker Det"!-project was conducted in 2016 by disseminating a questionnaire to the service providers in different Nordic countries offering help by various methods to perpetrators of DV and IPV. The questionnaire was built on a prior project questionnaire used at the European level - Work with Perpetrators of Domestic Violence in Europe - Daphne II Project 2006-2008, as to allow some comparisons between the Nordic states and the European counterparts.

This final report of the project offers valuable information on the differences and similarities in the Nordic policies on services for people who either have used violence or are afraid of using violence in their intimate relationships. The information is useful for policy makers, practitioners and researchers in the field of preventing and combatting gendered violence. The report contributes to the service development needs of the Nordic countries, especially with respect to the recent developments in the human rights regime related to violence against women.

During recent years, each European Union member state has signed the Istanbul convention, namely the Council of Europe Convention on preventing and combating violence against women and domestic violence. Three out of five of the Nordic countries have also ratified it. Article 16 of the convention requires the state parties to take the necessary legislative or other measures to set up or support programmes aimed at teaching perpetrators of domestic violence to adopt non-violent behavior in interpersonal relationships with a view to preventing further violence. Perpetrator 
programs are an integral part of the preventive measures required by the convention to combat violence against women.

The development of services and treatment programmes for IPV, DV and sexual abuse perpetrators can have a significant role in the overall complement of improved legal, social, medical and community responses to gendered violence. I hope that this report contributes to the advance of these responses.

Martta October

Project Leader

Development Manager, Master of Laws 


\section{Acknowledgements}

Firstly, we would like to express our gratitude to the practitioners in each Nordic country who participated in this project by providing answers to our questionnaire at substantially high rate. We would like to thank prof. Juha Holma and Minna Piispa for their advice and input to the drafting of the project questionnaire. This final report owes to the country reporters who collected and combined the data from each country; Mariana Dufort (Sweden), Ask Elklit and Sarah Bogelund Dokkedahl (Denmark, Greenland and Faroe Islands), Kristín I. Pálsdóttir (Iceland) and Ingunn Rangul Askeland (Norway). The report on Finland and Åland Islands was compiled by Martta October.

In addition to the Nordic Council of Ministers who initiated and funded this project during the Finnish chairmanship, we would like to gratefully thank the Ministry for Social Affairs and Health for their support and advice in realizing this project, especially Päivi Yli-Pietilä and Heidi Haggrén, who provided us with insightful comments along the way. Also, we would like to thank our Icelandic counterpart, University of Iceland Institute for Gender, Equality and Difference (RIKK), with whom we successfully organized an international conference Confronting gendered violence - focus on perpetrators in Helsinki in 3oth November - 2nd December, 2016.

Lastly, we would like to thank the Nordic Committee of Senior Officials for Gender Equality (ÄK-JÄM) for their support, advice and comments for the Final report as well as enabling us to publish via Norden publications.

Martta October

Project leader
Berta Vall

Project coordinator 



\section{Summary}

In this Report, the results of the "Nu Räcker Det" project are presented. This project, was funded by the Nordic Council of Ministries, and its main aim was to map out the different models used in the Nordic countries/territories (including the autonomous regions of Åland Islands, Greenland and Faroe Islands) to help the perpetrators of intimate partner violence (IPV) to break the cycle of violence. The project began in January 2016 by drafting a questionnaire, which was filled in by the service providers. Each country presented the results on a Country Report, which were integrated in this final report.

The questionnaire was designed to establish general facts about the local programmes, such as the number of programmes included, their funding, their general functioning (in terms of how are their services made available, how are the perpetrators contacted or referred, the treatment methodology followed). It was divided in different sections: A: basic information; B: staff; C: funding; D: cooperation and context, E: content of work, F: partner contact, and G: quality assurance.

The questionnaire to all the identified service providers service providers across the Nordic countries/territories (a total of 68 programmes), and it was responded by 53 programmes; therefore, the response rate was quite high (77.9\%). As expected, the number of programmes that are offered in each Nordic country, showed a great variety.

Regarding the main results obtained most of the service providers are allocated in a urban area. Moreover, long-term funding is not very common in the Nordic Countries. One third of the staff works part-time, and it is mostly composed by psychologists. The most common path of entry is the self-referred and referred by other institutions. The main services offered by the programmes are for male, female, and same sex perpetrators, as well as female and male victims of violence. Few services for children witnesses of violence are offered. There is a lack of clarity and consensus regarding the working methodology, and results evidence a great variety of approaches, both among countries and within each country. Most of the programmes contact the partner at the beginning of the treatment, and in crisis situations. However, half of the programmes do not contact the partner during the treatment or at the end of it. Almost $20 \%$ of the programmes do not measure the outcome and external evaluation is rarely present. Motivation towards the programme acquires a special relevance as for the intake requirements. The completion rate of around half of the programmes was from 50 to $75 \%$. Finally, the main challenges for the future, stated by the service providers are: to achieve permanent funding so as to be able to conduct long-term planning and to hire permanent staff; to widen the range of services offered so as to cover also abused children, female perpetrators of ethnic minorities, to solve the geographic inequality in access to services; to increase training and education of staff working in this field, and to increase cooperation and collaboration within institutions. 
Conclusions and discussion of the results are based on their comparison to the European context and to the minimum standards at the European level. When comparing the Nordic results to the European context, it seems that the programmes offered tend to be slightly older, so that they started earlier offering services. Another interesting comparison is that there is less cooperation with the women services in the Nordic context, however, more programmes include a support service for the (ex-) partners and more programmes contact the (ex-) partners. Moreover, in the Nordic context, there are more voluntary self-referrals, and thus, motivation towards the programme emerges as an important intake requirement. Gender specific/feministic approaches were more relevant in the Nordic countries, and couples counselling was much more present than in Europe.

Conclusion and discussion section, also includes some final thoughts and recommendations of future steps, and some limitations of the study and recommendations for future research or similar studies. Main future recommendations can be summarized as follows: Services should be available free of charge, and be equitably distributed across geography of the country. Long-term commitment in terms of financial resources is required. Different referral routes or paths of entry should be accommodated. Staff should be specialized and programmes should focus recognizing the gendered dynamics, impacts, and consequences of violence. Partner should be included in the treatment process in different forms. Risk assessment and management should be included in all the programmes. Programme evaluation should triangulate data sources to measure outcomes/success to include partner reports and official data. Perpetrators' motivation to complete treatment should be constantly monitored, and finally, measures to maximize completion rates should be taken. 


\section{Introduction}

In this Report, we will present the results of the "Nu Räcker Det" project, which is a Nordic project funded by the Nordic Council of Ministries aimed at mapping out the different models used in the Nordic countries/territories to help the perpetrators of intimate partner violence (IPV) to break the cycle of violence.

Very recently, the EU Fundamental Rights Agency has reported the results of a survey of women in the 28 member states. These results revealed that one in three women reported having suffered some form of physical or sexual abuse since the age of 15 ; this means that in total more than 62 million women in Europe have suffered some form of physical or sexual abuse (FRA, 2014).

It has been argued that gender equality is a necessary condition to reduce IPV towards women. Yet, despite equality between men and women being a fundamental value in Nordic countries/territories and this region being the most gender equal region in the world, they also present high rates of IPV against women (above the EU average) (Gracia \& Merlo, 2016). Thus, what has been called the "Nordic Paradox" is constructed.

Does this prove that greater gender equality fails to promote a decrease in IPV? This inference cannot be automatically drawn, since, for example, gender equality leads to IPV being recognized, reported, and considered as a problem more easily than in less gender equal societies. Despite this, one could hypothesize that very equal societies also promote a clash among individual perceptions and expectations about womanhood and manhood and the normative equality view (Gracia \& Merlo, 2016). Thus, the two levels are of great importance for generating an equal society: the societal level, and the individual and interactional level; so that both the mindset and the social background can be similar and emphasize more equal gender positions. Therefore, perpetrator programmes seem crucial in undertaking this task. This is the focus of the "Nu Räcker Det" project that is presented in this Report.

\section{Perpetrators programmes in Europe: best practices and minimum standards}

\section{Normative background}

Several international human rights conventions aim at reducing violence against women (WAV) and domestic violence (DV). The most recent on the European level is the Council of Europe Convention on preventing and combating violence against 
women and domestic violence (Istanbul Convention). ${ }^{1}$ This new treaty opened the path for creating a legal framework at the pan-European level to protect women against all forms of violence, and prevent, prosecute, and eliminate violence against women and domestic violence. The Istanbul Convention recognizes that violence against women is a manifestation of historically unequal power relations between women and men, and recognizing the structural nature of violence against women as gender-based violence. Moreover, it also recognizes that violence affects women disproportionately, and that men may also be victims of domestic violence.

The Convention also established a specific monitoring mechanism ("GREVIO") in order to ensure effective implementation of its provisions by the Parties. The Convention came into force in Finland on 1/08/2015, Denmark 01/08/2014, and Sweden $01 / 11 / 2014$, whereas in Iceland and Norway it has not yet come into force but it was signed on 11/05/2011 and 07/07/2011, respectively (Council of Europe, 2016).

Article 16 of the Convention regulates preventive intervention and treatment programs and requires states parties to set up or support two separate types of programmes: those targeting domestic violence perpetrators (Article 16, paragraph 1) and others designed for sex offenders (Article 16, paragraph 2).

Article 16 - Preventive intervention and treatment programmes

(1) Parties shall take the necessary legislative or other measures to set up or support programmes aimed at teaching perpetrators of domestic violence to adopt non-violent behavior in interpersonal relationship with a view to preventing further violence and changing violent behavioral patterns.

(2) Parties shall take the necessary legislative or other measures to set up or support treatment programmes aimed at preventing perpetrators, in particular sex offenders, from re-offending.

(3) In taking the measures referred to in paragraphs 1 and 2, Parties shall ensure that the safety of, support for and the human rights of victims are of primary concern and that, where appropriate, these programmes are set up and implemented in close co-ordination with specialist support services for victims.

More especially, Article 16 outlines that these programmes must ensure the safety and support of victims and that specialist support services such as women's shelters or rape crisis centres should be turned to for co-operation in this regard. (Hester \& Lilley, 2014). Moreover, programmes should be based on best practices and evidence-based research on the effectiveness of perpetrator treatment. Programmes should encourage perpetrators to take responsibility for their actions and examine their attitudes and beliefs towards women. This type of work requires skilled and trained facilitators. Beyond training in psychology and the nature of domestic violence, they need to possess the cultural and linguistic skills that will enable them to work with a wide diversity of men attending such programmes (Council of Europe, 2011).

${ }^{1}$ Full text of the Istanbul Convention is available at:

https://rm.coe.int/CoERMPublicCommonSearchServices/DisplayDCTMContent?documentld=090000168046031C 
According to the Convention, perpetrator programmes are important elements of an integrated and comprehensive approach to preventing and combating violence against women, which, in turn, should be part of a comprehensive national policy or strategy. Article 16 is rooted in the desire to develop a response to individual perpetrators who use physical, psychological, or sexual violence against women (Hester \& Lilley, 2014). It requires State parties to invest in programmes for domestic violence perpetrators and for sex offenders (Article 16).

\section{Defining what works and establishing bests practices}

To date, research from Europe and North America has failed to discern which treatment approaches work better than others because many programmes use a mix of treatment methods, making any kind of robust evaluation difficult in terms of identifying the effects of the different programme components (Akoensi et al., 2012).

Effectiveness is difficult to measure in IPV treatments, the main problem being that there is no suitable research frame to measure outcomes and thus the research has received strong methodological criticisms (Stover, Meadows \& Kaufman, 2009; Wathen \& MacMillan, 2003; Kelly \& Westmarland, 2015).

Group interventions with IPV perpetrators, following various approaches, have been shown to have a minimal impact on reducing the recidivism of domestic violence (Babcock, Green, \& Robie, 2004). However, Gondolf (2003) has pointed out that those results might be because interpretation of results is difficult as the programs have different conceptions and modalities (i.e. manualized or not), happen in different settings/contexts, while men's characteristics are not taken into account (which can influence outcomes like motivation) and studies on effectiveness use different outcome measures, research designs, and statistical analysis that can produce very varied results.

Recently, the European Council has tried to solve these difficulties by elaborating on a series of papers by the European Council in light of the Istanbul Convention (see Hester \& Lilley, 2014 and Kelly \& Chair, 2008). Those are very useful tools based on best practices and minimum standards for perpetrators programmes, which include practical advice to policymakers and practitioners on the design of the required intervention programmes.

What follows is a presentation of the overachieving principles that perpetrators programmes should follow, and some current standards included in each, based on the above-mentioned studies (see Hester \& Lilley, 2014 and Kelly \& Chair, 2008):

\section{Working from a gender analysis perspective}

Programmes should recognize the gendered dynamics, impacts, and consequences of violence against women within an equalities and human rights framework.

Safety, security, and human dignity

All interventions should prioritize the safety, security, and dignity of service users and of staff.

Programmes should: 
- Prioritize the safety of the (ex-) partners and their children by working in collaboration with victim support services.

- Offer (ex-) partners both group and individual support and assure that they are informed about the goals and the content of the programme, its limitations, and how their partner can use his/her attendance to manipulate or control him/her.

\section{Specialist services}

The knowledge and skills of the staff should be specialised (high level of qualification and training for facilitators should be ensured)

Programmes should:

- Take into account the different sources of motivation at intake assessment and monitor this throughout the programme. Therefore, changes in motivation should be detected.

- Take measures to maximize programme retention and completion.

- Implement systematic risk assessment and management; both at the intake phase and when there might be a possible change in the level of risk. Risk assessment as a minimum, should include the victim/partner's perspective and any official data available (police and other agency data).

Diversity and fair access

Treatment should be available free of charge, equitably distributed across the geography of the country, while crisis provision should be available 24/7.

\section{Advocacy, support, and empowerment}

Services should provide both case and system advocacy to support and promote the needs and rights of service users. Moreover, they should ensure that the service users are familiar with their rights and entitlements.

\section{Participation and consultation}

Promote service-user involvement in the development and evaluation of the service.

Confidentiality

Ensure that all service users are informed of situations where confidentiality may be limited.

\section{A coordinated response}

Services should operate within a context of inter-agency cooperation, collaboration and coordinated service delivery.

Programmes should:

- Be implemented as part of an integrated/multi-agency approach and delivered over a minimum of two years (therefore they require long-term commitment in terms of financial resources). 
- Accommodate different referral routes or paths of entry (need for both voluntary and court-mandated perpetrator programmes).

Holding perpetrators accountable

Respect for victims should be emphasized, and perpetrators should be held accountable for their actions.

Programmes should:

- Work towards a clear definition of violence against women and with the principle that violence against women and children is unacceptable and that perpetrators are accountable for their abusive behaviour.

- Include the perspective of children living in abusive relationships as a priority.

- Assist perpetrators to change by recognizing that their use of violence is a choice that they make and challenge any denial, justification or blaming of others (while treating the perpetrator with respect).

\section{Challenging tolerance}

Use gender analysis to raise awareness, educate and undertake prevention work.

Evaluate both processes and outcome

Monitor, document and evaluate both processes and outcomes.

Programmes should:

- Work with a wide definition of "success" that includes the more "subtle" outcomes and based on the factors/variables that can be changed, such as perceived severity or assumed responsibility rather than an overall change in perpetrators" behaviour per se.

- Constantly monitor perpetrators" motivation to complete treatment and be able to identify different motivations and treatment trajectories. Success must not be measured on programme completion rates or self-reported levels of violence alone.

- Evaluation should triangulate data sources to measure outcomes/success to include women-partner reports where possible, as well as official data and selfreported levels of violence to measure whether the partners" or their children's safety, feelings of safety, or quality of life has improved.

- Evaluation should use comparison groups wherever possible and establish six months as the minimum period for follow-up after programme completion.

\section{Definitions and terminology}

As defined in Article 3 of the Istanbul Convention: "Domestic Violence" (DV) refers to all acts of physical, sexual, psychological, or economic violence that occur within the 
family or domestic unit or between former or current spouses or partners, whether or not the perpetrator shares or has shared the same residence with the victim.

"Gender-based" violence against women is defined as violence that is directed against woman because she is a woman or that affects women disproportionately.

The term "Intimate Partner Violence" (IPV) is generally used to describe physical violence, sexual violence, stalking, and psychological aggression (including coercive acts) by a current or former intimate partner (i.e., spouse, boyfriend/girlfriend, dating partner, or ongoing sexual partner) (Breiding et al., 2015, p.11).

As can be seen in these definitions, the term "domestic violence" (DV) is wider in scope, as this term can also encompass child or elder abuse, or abuse by any member of a household.

In this project the questionnaire used both the terms DV and IPV, but in order to limit the scope of the surveyed service providers, the project narrowed the definition of $D V$ to cover only violent behaviour between adult partners in an intimate relationship. This ruled out for example services solely directed to abusive parents or perpetrators of violent behaviour towards children as well as violent behaviour between friends or street violence. In order to avoid misconceptions, the terms used were defined at the introduction of the project questionnaire that was sent to the service providers for completion. Both DV or IPV were defined as follows: "The physical, mental, sexual, emotional, verbal, and/or economic abuse of one partner by another in close adult relationships, including the threat of violence as well as the use of violence. Partners may be married or not married; heterosexual, gay, or lesbian; living together, separated or dating."

Moreover, the introduction of the questionnaire also included other definitions of the terms used in it, such as "work", "model" and "programme", which were defined to mean "specific work with male and/or female perpetrators of intimate partner violence". The terms "participant" and "client" were defined to mean both a participant of group work and a client of face-to-face work.

\section{Description of the project "Nu Räcker Det"}

This is the Final Report from a Nordic collaboration project called "Nu Räcker Det" funded by the Nordic Council of Ministers. This project aims to map out the different models used in the Nordic countries/territories to help the perpetrators of intimate partner violence (IPV) or domestic violence (DV) within adult partnerships to break the cycle of violence.

The project began in January 2016 by drafting a questionnaire (see Appendix 1), which was sent to all five Nordic countries, including the autonomous territories of Åland Islands, Greenland, and the Faroe Islands. The questionnaire was completed by the service providers, each of which may use different models to help the perpetrators. Each country reported the data provided by the service providers as a Country Report. 


\section{Methodology}

\subsection{Questionnaire}

The questionnaire used in this project is based on a previous project "IMPACT: Evaluation of European Perpetrator Programmes", funded by The Daphne III Programme to combat violence against children, young people and women in $2007 .{ }^{2}$ The service coordinating of the project, Dissens - Institut für Bildung und Forschung e.V. from Germany, worked together with six other organisations, from Austria, Denmark, Spain and the U.K. and two associated partners from Germany and Norway. This project aimed at improving the quality of the service providers for perpetrators in Europe, with a special focus on the monitoring and evaluation procedures followed by them. One of the main outcomes of the project was the elaboration of a Toolkit to improve and unify the outcome measurement of the service providers. We have acquired permission to use it as the basis for our questionnaire and also to allow for possible comparisons of the results. The questionnaire was used in the first study of the IMPACT project (Geldschläger, et al., 2014) and the Nordic results of this project will be compared with the European results of their study.

The questionnaire was designed to establish general facts about the local programmes, including "how many different models or programs to end violent behaviour are offered to perpetrators of domestic violence in each country/area?" "How are the programmes or models funded?" "How are the services or programmes made available to the perpetrators or potential perpetrators of domestic violence?" "How are the clients, i.e. the perpetrators contacted or directed to these services?" "What are the methods used in the programmes or models and what scientific background are they based on, if any?" The project also aims to map out the different working methods used with the clients. These may include individual therapy, group discussions, etc. and may vary from service provider to another. The questionnaire was modified to fit better the specific information needs of the individual Nordic countries/territories. For example, an interest in finding out details about the funding and methodology of the different models used in each country led to adding questions on those themes.

\footnotetext{
${ }^{2}$ The Working paper 1 from the Daphne III project IMPACT: Evaluation of European Perpetrator Programmes can be found at: http://www.work-with-perpetrators.eu/fileadmin/WWP_Network/redakteure/IMPACT/Daphne_III_Impact_-

_Working_paper_1_-_Outcome_Measurement_in_European_Perpetrator_Programmes_-_A_Survey.pdf
} 


\subsection{Sample}

Total sample of invited programmes in all Nordic Countries was 68 and the response rate was around $80 \%$, with 53 service providers finally answering the questionnaire and taking part in the project.

\subsection{Data collection and analysis}

The data were collected in May 2016 by sending a questionnaire to each of the identified IPV-perpetrator service providers all over the Nordic countries/territories. Each country's contact person was in charge of elaborating a Country Report with the data provided by the service providers.

Finally, a Final Report including information from all Country Reports was compiled and is presented here. 


\section{Results}

The main results of the questionnaire are described reporting the frequencies of responses to each question and the corresponding percentage. Most of the questions were multiple choice, as indicated in each results table with the label "more than one option could be ticked". Respondents who ticked the "others" option were asked to specify and describe this answer in an open text field. When those responses were present, they have been added in a more or less literal way in the explanations following the tables.

\subsection{Section A: basic information}

In this section the main survey results on the characteristic of the programmes are described.

\subsubsection{Country response rate}

In what follows, Table 1 and 2 show information on the response rate per Nordic Country and the final participating programmes per country, together with the percentage that they represented of the total programmes in the Nordic Region.

As can be seen in Table 1 the questionnaire was sent to 68 service providers across the Nordic countries/territories, with the response rate being quite high (77.9\%).

Table 1: Response rate per country/territory

Iceland

Sweden

Denmark

Faroe Islands

Greenland

Norway

Total

\begin{tabular}{rr}
20 & 80 \\
1 & 100 \\
1 & 100 \\
28 & 60.7 \\
4 & 100 \\
1 & 100 \\
1 & 100 \\
$12 *$ & $100 *$ \\
68 & 77.9 \\
\hline
\end{tabular}

Note: *Norway contacted more programmes ( $n=193$ from 1,182 to whom the questionnaire was sent; response rate $16.3 \%$ ), but for the Final Report, just the programmes that were specialized in the treatment of IPV (11 service providers from Alternative Til Vold; ATV) and 1 from Broset Domestic Violence treatment programme (SBM) were taken for analysis. Therefore, this study does not include the services provided by the Family Counselling service or the services provided by the specialist health services (for more information see the Norwegian Report). 
As can be seen in Table 2 the number of programmes that are offered in each Nordic country, as expected, show a great variety, the lowest being one programme in one country/territory (i.e. Åland, Iceland, Greenland, and Faroe Islands), representing a bit less than $2 \%$ of the sample, and the highest being 17 (i.e. Sweden), representing a bit more than a third of the sample.

Table 2: Programmes that answered the questionnaire in each country/territory and percentage of all the Nordic countries/territories

\begin{tabular}{lrr}
\hline Country & & Programmes per Country \\
& Frequency & Percentage \\
Finland & $14^{*}$ & 26.4 \\
Åland & 1 & 1.9 \\
Iceland & 1 & 1.9 \\
Sweden & 17 & 32.1 \\
Denmark & 4 & 7.5 \\
Faroe Islands & 1 & 1.9 \\
Greenland & 1 & 1.9 \\
Norway & 12 & 22.6 \\
Total & 53 & 100 \\
\hline
\end{tabular}

Note: *In the Finnish Report, 16 questionnaires were answered, while for this Final Report, 14 were selected, as one questionnaire came from the Åland Islands (which will be considered separately in this Report), and the other was completed by the Criminal Sanctions Agency (RISE) regarding the models used in Finnish prisons (see Finnish report for more information).

\subsubsection{Part of a wider organisation / institution / public service / NGO}

More than half of the programmes $(n=30 ; 62.5 \%)$ were organized by an NGO, whereas about a third were organised by a wider organization $(n=16 ; 33.3 \%)$.

In the case of Finland all the programmes $(n=14)$ were organised by nongovernmental organizations, while similarly in Norway most of the programmes $(n=11$; 91.7\%) were organized by non-governmental organizations. In Denmark about half of the services $(n=2)$ were organized by non-governmental organizations. Whereas in Sweden, non-governmental organizations organized only $17.7 \%(n=3)$. In the case of Iceland, the Faroe Islands and Greenland the sole service provider in those countries was part of a wider organization.

Table 3: Part of a wider organisation / institution / public service / NGO

\begin{tabular}{|c|c|c|c|c|c|c|c|c|c|c|c|c|c|c|c|c|}
\hline & \multicolumn{2}{|c|}{ Finland } & \multicolumn{2}{|c|}{ Iceland } & \multicolumn{2}{|c|}{ Sweden } & \multicolumn{2}{|c|}{ Denmark } & \multicolumn{2}{|c|}{$\begin{array}{l}\text { Faroe } \\
\text { Islands }\end{array}$} & \multicolumn{2}{|c|}{ Greenland } & \multicolumn{2}{|c|}{ Norway } & \multicolumn{2}{|c|}{ Total } \\
\hline & $\mathbf{F}$ & $\%$ & F & $\%$ & $\mathbf{F}$ & $\%$ & $\mathbf{F}$ & $\%$ & $\mathbf{F}$ & $\%$ & $\mathbf{F}$ & $\%$ & $\mathbf{F}$ & $\%$ & $\mathbf{F}$ & $\%$ \\
\hline Yes & & & 1 & 100 & 12 & 70.6 & & & 1 & 100 & 1 & 100 & 1 & 8.3 & 16 & $33 \cdot 3$ \\
\hline NGO & 14 & 100 & & & 3 & 17.7 & 2 & 50 & & & & & 11 & 91.7 & 30 & 62.5 \\
\hline Other & & & & & 2 & 11.8 & & & & & & & & & 2 & 4.2 \\
\hline $\begin{array}{l}\text { No. per } \\
\text { country }\end{array}$ & 14 & & 1 & & 17 & & 2 & & 1 & & 1 & & 12 & & 48 & \\
\hline
\end{tabular}

Note: $\quad \mathrm{N}=48$. 
Figure 1: Services part of a wider organisation / institution / public service / NGO

PART OF AN INTER-INSTITUTIONAL ALLIANCE OR NGO

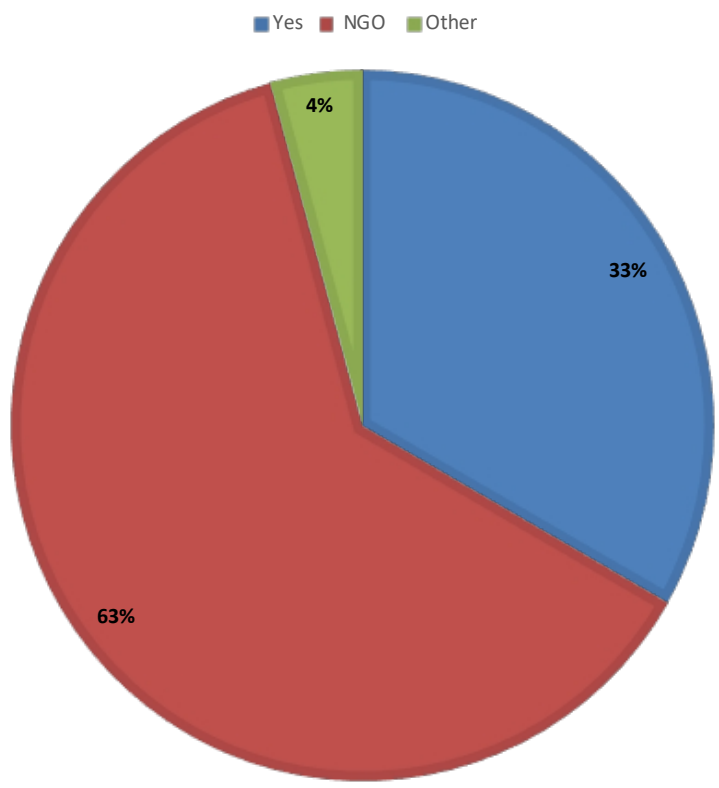

Figure 2: Services part of a wider organisation / institution / public service / NGO

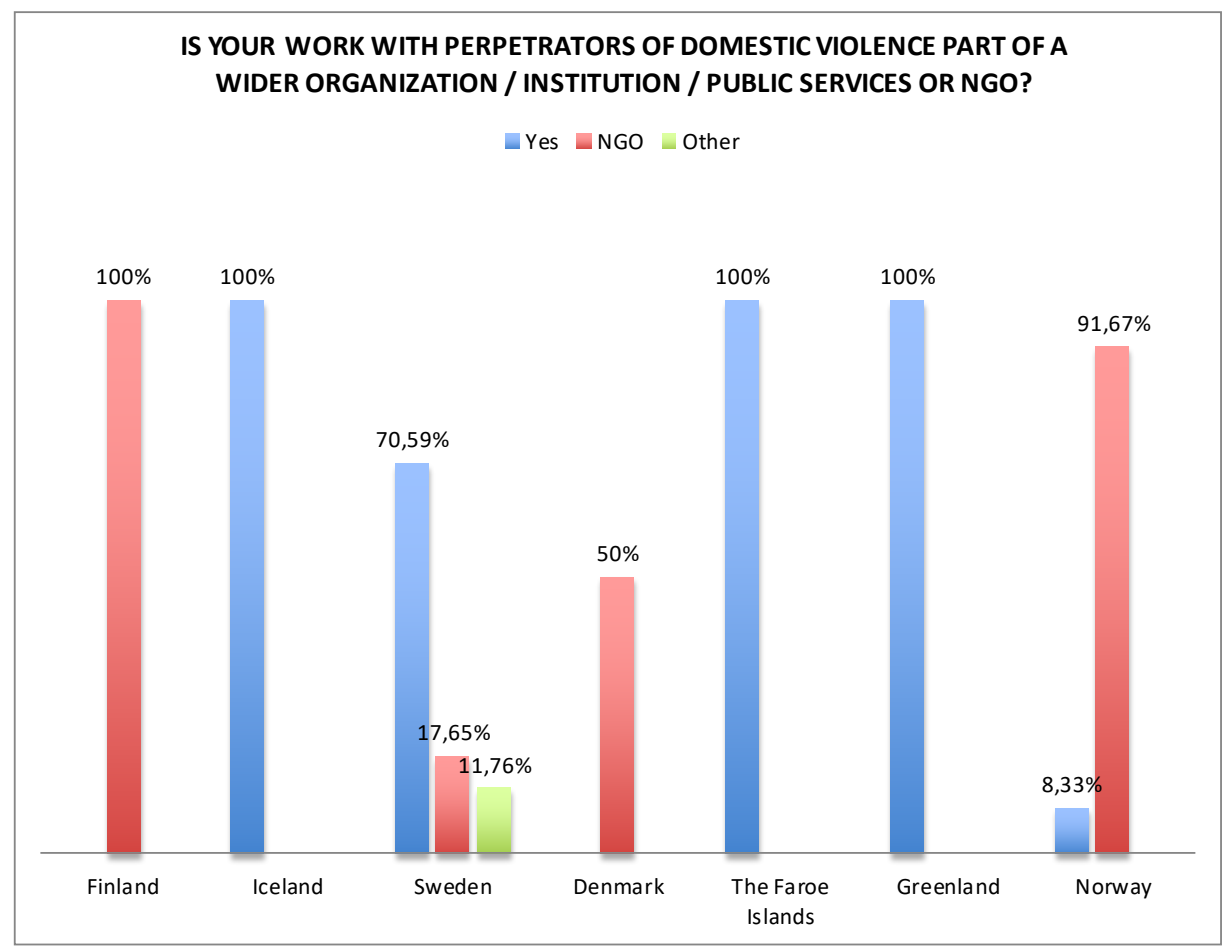




\subsubsection{Name of the Programme}

Just six programmes (11.3\%) from Sweden reported that they did not have any specific name.

The names of the rest of the programmes varied; some answers where analogous with the name of the method used in the treatment, for example ATV, or the service offered, for example, Miesten kriisikeskus (Men's Crisis Center, in Finland), Men's Advisory" (Manderådgivningen, in Denmark).

ATV is present more prominently and under the same name in Åland (called Alternativ till vald in Swedish), in Denmark, in Greenland and, in the country where it originated, Norway. Although many service providers from other Nordic countries reference having been strongly influenced by it.

The SBM (Broset Domestic Violence treatment programme), an outpatient treatment unit that has developed its own manual based on cognitive therapy, is present in Norway (one service provider).

\subsubsection{Location of the programme}

As reflected in Table 4 , the vast majority $(n=42 ; 84 \%)$ of the programmes were located in an urban area. Seven (14\%) were in a Peri-urban area, and just one in Sweden was in a rural area.

Table 4: Location of the programme

\begin{tabular}{|c|c|c|c|c|c|c|c|c|c|c|c|c|c|c|c|c|}
\hline \multirow[b]{2}{*}{ Arear } & \multicolumn{2}{|c|}{ Finland } & \multicolumn{2}{|c|}{ Iceland } & \multicolumn{2}{|c|}{ Sweden } & \multicolumn{2}{|c|}{ Denmark } & \multicolumn{2}{|c|}{$\begin{array}{l}\text { Faroe } \\
\text { Islands }\end{array}$} & \multicolumn{2}{|c|}{ Greenland } & \multicolumn{2}{|c|}{ Norway } & \multicolumn{2}{|c|}{ Total } \\
\hline & $\mathbf{F}$ & $\%$ & $\mathrm{~F}$ & $\%$ & $\mathbf{F}$ & $\%$ & $\mathbf{F}$ & $\%$ & $\mathbf{F}$ & $\%$ & $\mathbf{F}$ & $\%$ & $\mathbf{F}$ & $\%$ & $\mathrm{~F}$ & $\%$ \\
\hline $\begin{array}{l}\text { Urban } \\
\text { Rural }\end{array}$ & 14 & 100 & 1 & 100 & $\begin{array}{r}13 \\
1\end{array}$ & $\begin{array}{r}76.5 \\
5.9\end{array}$ & 2 & 50 & 1 & 100 & 1 & 100 & 10 & 83.3 & $\begin{array}{r}42 \\
1\end{array}$ & $\begin{array}{r}84 \\
2\end{array}$ \\
\hline Peri-urban & & & & & 3 & 17.6 & 2 & 50 & & & & & 2 & 16.7 & 7 & 14 \\
\hline $\begin{array}{l}\text { N per } \\
\text { country }\end{array}$ & 14 & & 1 & & 17 & & 4 & & 1 & & 1 & & 12 & & 50 & \\
\hline
\end{tabular}

Note: $\quad \mathrm{N}=50$. 


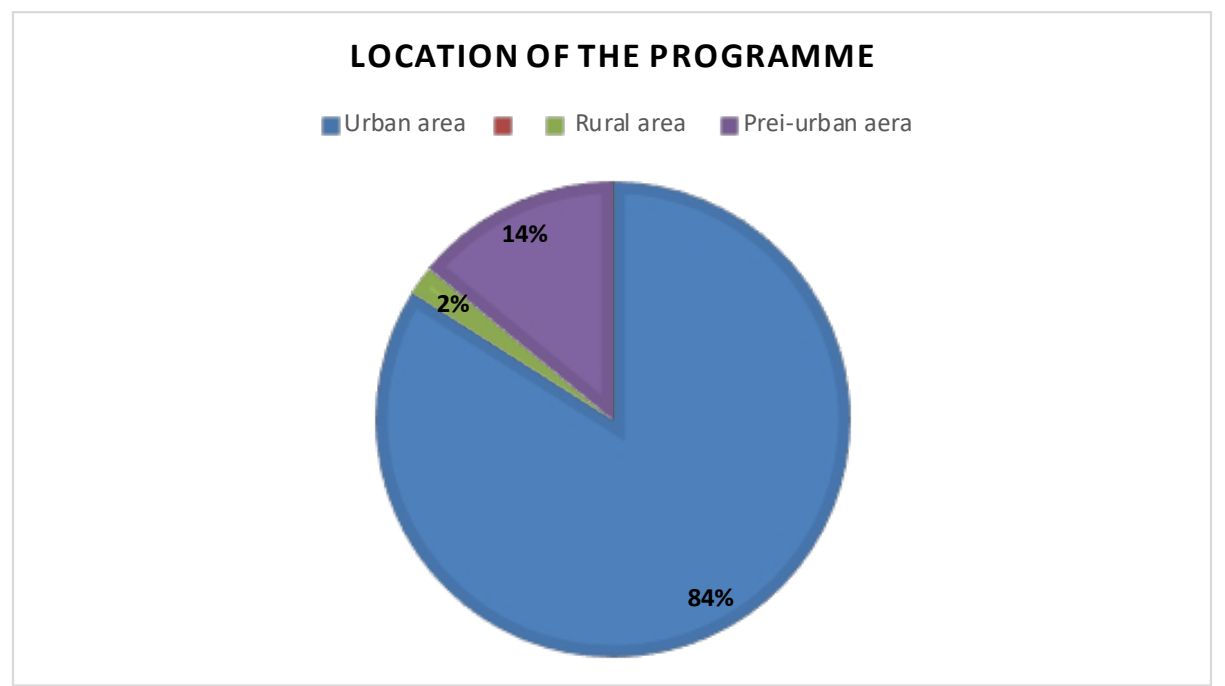

Figure 4: Location of the programme

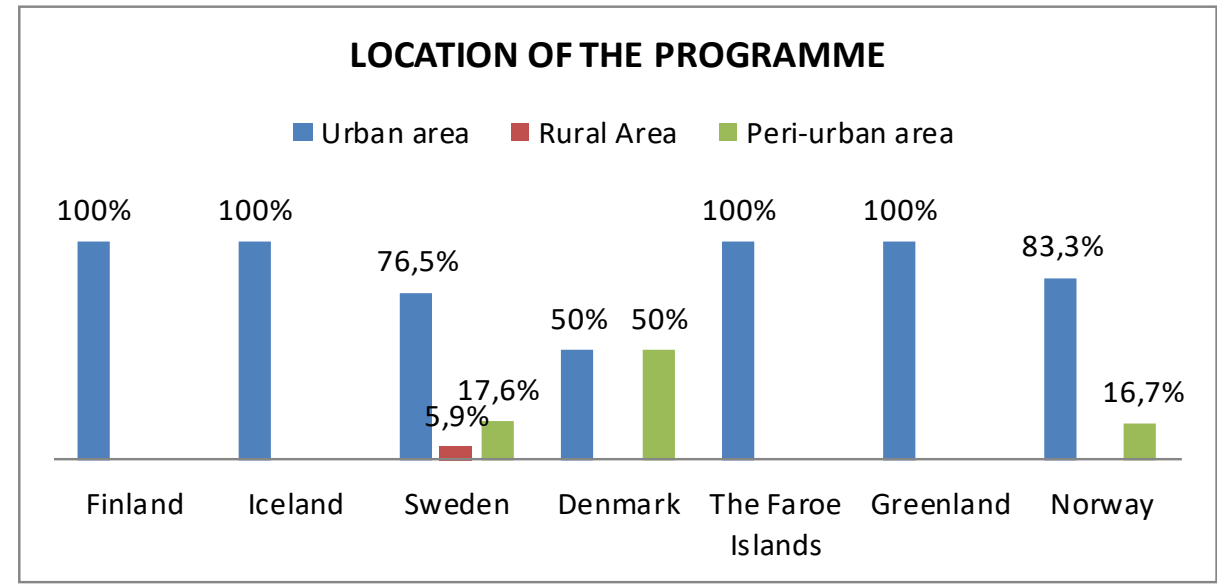

\subsubsection{Age of the programmes}

The responses to the question "when did your programme start?" varied from 1986 to 2016; there was even one program in Greenland that had just started a few months before the questionnaire was completed. These responses where recoded into the following categories: "very old" programmes that started up to the year 2000, "old" programmes that started between 2001 and 2005, "young" programmes that started between 2006 and 2010, and "new" programmes that have started since 2011.

As can be seen in Table 5, more than half of the programmes ( $n=29 ; 59.2 \%)$ fall into the category of "very old", followed by $20.4 \%(n=10)$ of "new" programmes. Sweden and Denmark had the most varied results in all the categories, whereas Iceland, Norway, and Finland mostly had "very old" programmes. 
Table 5: Age of the programme

\begin{tabular}{|c|c|c|c|c|c|c|c|c|c|c|c|c|c|c|c|c|c|c|}
\hline & \multicolumn{2}{|c|}{ Finland } & \multicolumn{2}{|c|}{ Åland } & \multicolumn{2}{|c|}{ Iceland } & \multicolumn{2}{|c|}{ Sweden } & \multicolumn{2}{|c|}{ Denmark } & \multicolumn{2}{|c|}{$\begin{array}{l}\text { Faroe } \\
\text { Islands }\end{array}$} & \multicolumn{2}{|c|}{ Greenland } & \multicolumn{2}{|c|}{ Norway } & \multicolumn{2}{|c|}{ Total } \\
\hline & $F$ & $\%$ & F & $\%$ & F & $\%$ & $F$ & $\%$ & $F$ & $\%$ & $F$ & $\%$ & $F$ & $\%$ & F & $\%$ & F & $\%$ \\
\hline Very Old & 11 & 91.7 & & & 1 & 100 & 4 & 23.5 & 1 & 25 & & & & & 12 & 100 & 29 & 59.2 \\
\hline Old & 1 & 8.3 & 1 & 100 & & & 4 & 23.5 & 1 & 25 & & & & & & & 7 & 14.3 \\
\hline Young & & & & & & & 2 & 11.8 & 1 & 25 & & & & & & & 3 & 6.1 \\
\hline New & & & & & & & 7 & 41.2 & 1 & 25 & 1 & 100 & 1 & 100 & & & 10 & 20.4 \\
\hline $\begin{array}{l}\mathrm{N} \text { per } \\
\text { country }\end{array}$ & 12 & & 1 & & & & 17 & & 4 & & 1 & & 1 & & 12 & & 49 & 100 \\
\hline
\end{tabular}

Note: $\quad \mathrm{N}=49$.

Figure 5: Age of the programme

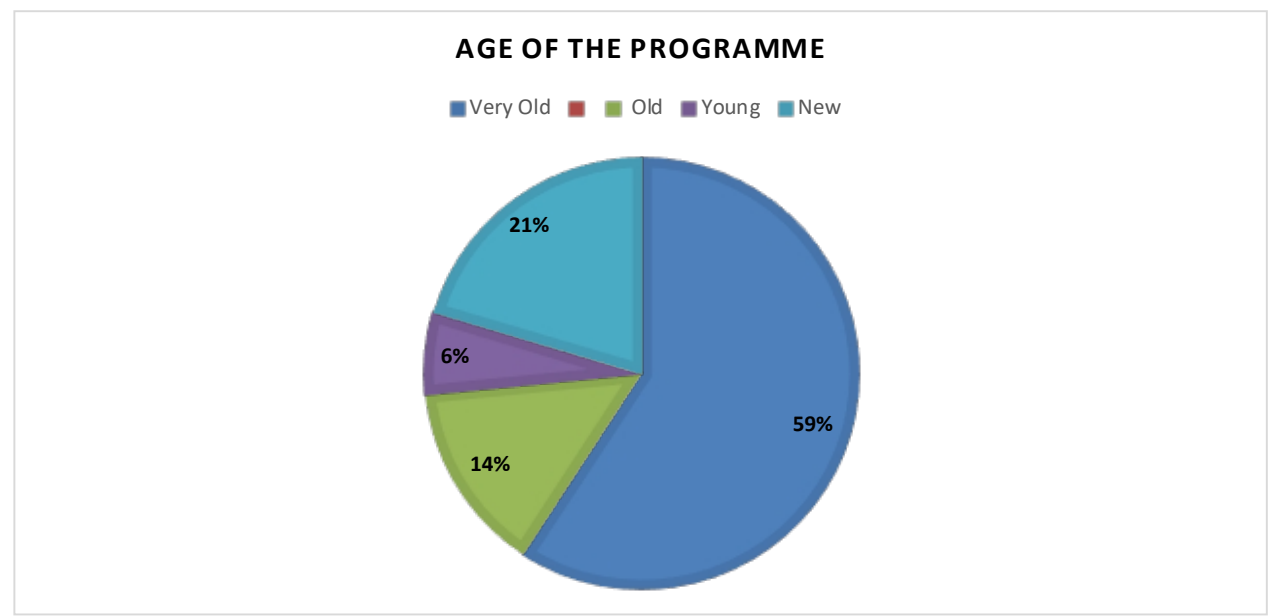


Figure 6: Age of the programme

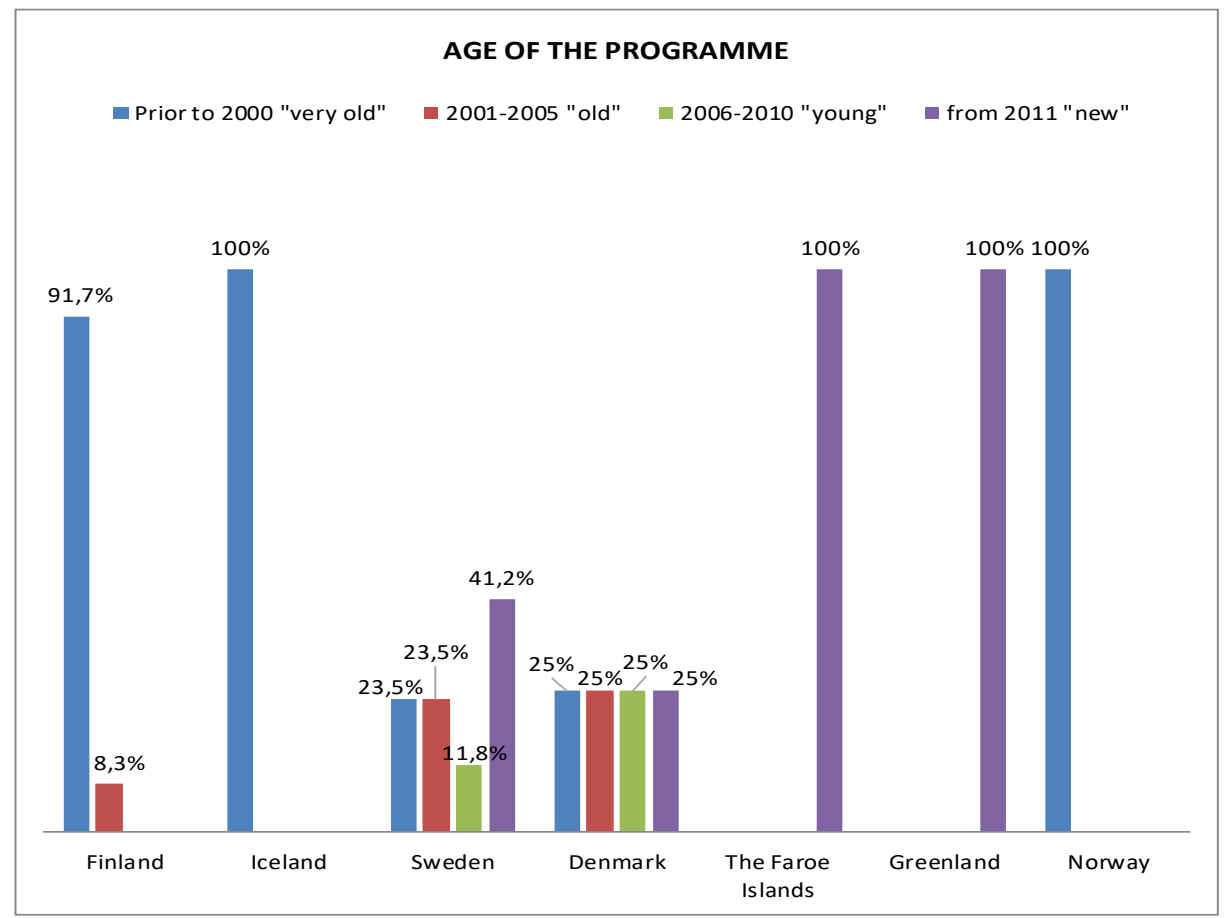




\subsection{Section B: Staff}

\subsubsection{Number of staff}

Table 6 shows the number of staff per country/territory. In order to provide some context to these results, the number of programmes per country/territory has also been added.

Comparing the number of staff to the number of service providers it seems quite balanced, the countries/territories that had more service providers also seemed to have more staff.

Table 6: Number of programmes and staff per country/territory

Country/territory Number of programmes per country/territory

Number of staff

Finland

Åland

Iceland

Sweden

Denmark

Faroe Islands

Greenland

Norway

Total

$\begin{array}{rr}16 & 62 \\ 1 & 2 \\ 1 & 5 \\ 17 & 40 \\ 4 & 29 \\ 1 & 1 \\ 1 & \mathrm{NA}^{*} \\ 12 & 53 \\ 52 & 192\end{array}$

Note: * No answer (the programme is not yet started).

\subsubsection{Gender}

Table 7 presents the frequency and percentages of staff in each category. The staff mainly consisted of female facilitators working full-time ( $n=69 ; 36.7 \%)$, male facilitators working full-time $(n=46 ; 24.5 \%)$ and male $(n=25 ; 13.3 \%)$ and female $(n=22 ; 11.7 \%)$ facilitators working part-time. In total, the number of part-time staff is quite high $(n=53 ; 28.2 \%)$. 
Table 7: Gender of staff

\begin{tabular}{|c|c|c|c|c|c|c|c|c|c|c|c|c|c|c|}
\hline & \multicolumn{2}{|c|}{ Finland } & \multicolumn{2}{|c|}{ Iceland } & \multicolumn{2}{|c|}{ Sweden } & \multicolumn{2}{|c|}{ Denmark } & \multicolumn{2}{|c|}{$\begin{array}{l}\text { Faroe } \\
\text { Islands }\end{array}$} & \multicolumn{2}{|c|}{ Norway } & \multicolumn{2}{|c|}{ Total } \\
\hline & $\mathbf{F}$ & $\%$ & $\mathbf{F}$ & $\%$ & $\mathbf{F}$ & $\%$ & $\mathbf{F}$ & $\%$ & $\mathbf{F}$ & $\%$ & $\mathbf{F}$ & $\%$ & $F^{*}$ & $\%$ \\
\hline Male facilitators full-time & 13 & 21.7 & & & 11 & 27.5 & 7 & 24.1 & 1 & 100 & 14 & 26.4 & 46 & 24.5 \\
\hline Female facilitators full-time & 13 & 21.7 & & & 7 & $17 \cdot 5$ & 10 & 34.5 & & & 39 & 73.6 & 69 & 36.7 \\
\hline Male facilitators part-time & 13 & 21.7 & 3 & 60 & 6 & 15 & 3 & 10.3 & & & & & 25 & 13.3 \\
\hline Female Facilitators part-time & 12 & 20 & 1 & 20 & 7 & 17.5 & 2 & 6.9 & & & & & 22 & 11.7 \\
\hline Male administration full-time & 2 & $3 \cdot 3$ & & & 1 & 2.5 & & & & & & & 3 & 1.6 \\
\hline $\begin{array}{l}\text { Female administration full- } \\
\text { time }\end{array}$ & 7 & 11.7 & & & 1 & 2.5 & 5 & 17.2 & & & & & 13 & 6.9 \\
\hline $\begin{array}{l}\text { Male administration part- } \\
\text { time }\end{array}$ & & & & & 1 & 2.5 & & & & & & & 1 & 0.5 \\
\hline $\begin{array}{l}\text { Female administration part- } \\
\text { time }\end{array}$ & & & 1 & 20 & 1 & 2.5 & 2 & 6.9 & & & & & 4 & 2.1 \\
\hline $\begin{array}{l}\text { Male administration } \\
\text { freelance }\end{array}$ & & & & & 2 & 5 & & & & & & & 2 & 1.1 \\
\hline $\begin{array}{l}\text { Female administration } \\
\text { freelance }\end{array}$ & & & & & 3 & 7.5 & & & & & & & 3 & 1.6 \\
\hline $\begin{array}{l}\text { N per countryl } \\
\text { territory }\end{array}$ & 60 & & 5 & & 40 & & 29 & & 1 & & 53 & & 188 & \\
\hline
\end{tabular}

Note: $\quad \mathrm{N}=188$.

*Each country/territory could specify the number of workers per dimension. 
Figure 7: Gender of staff

\section{GENDER OF STAFF}

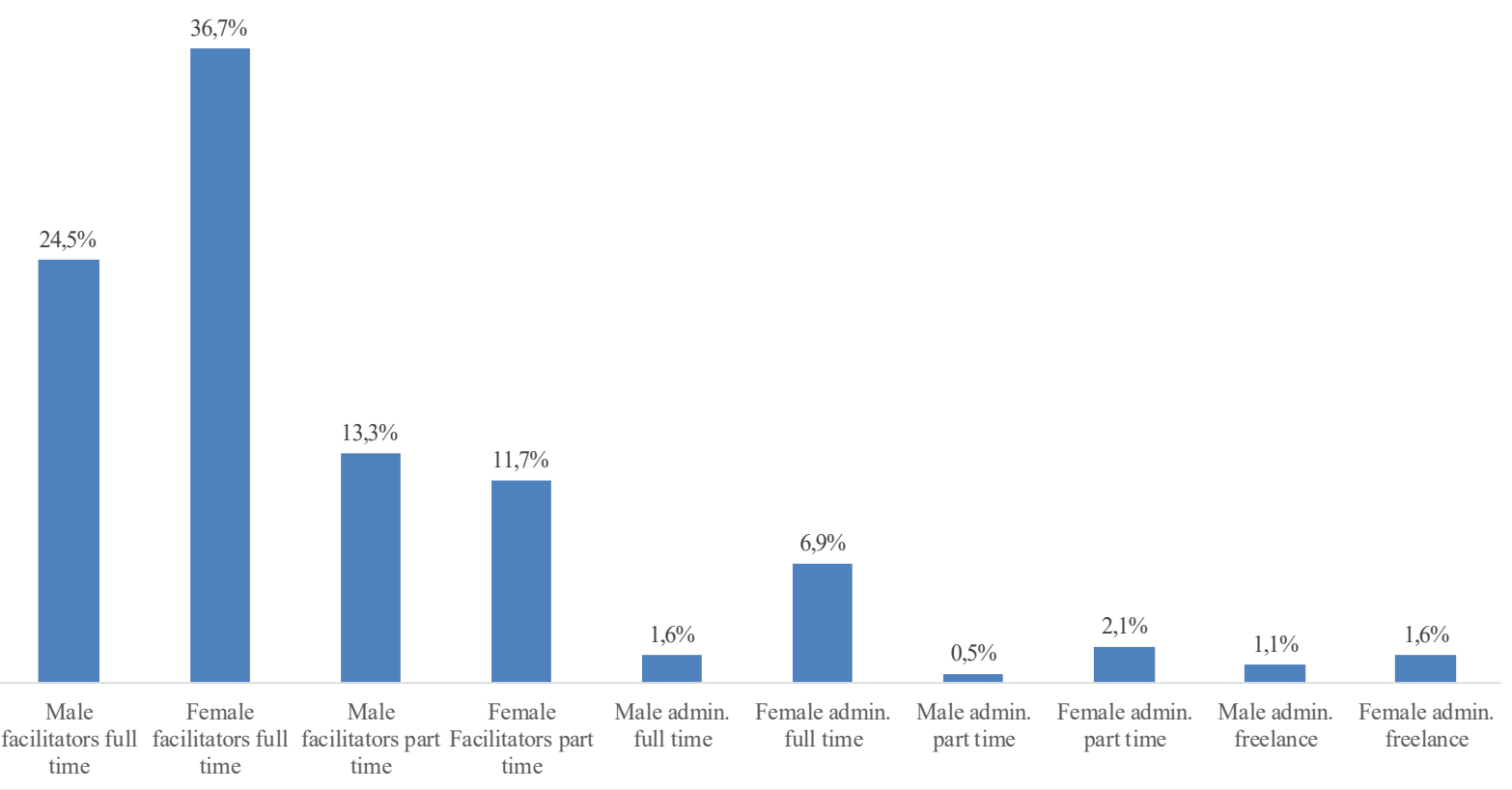

Figure 8: Gender of staff

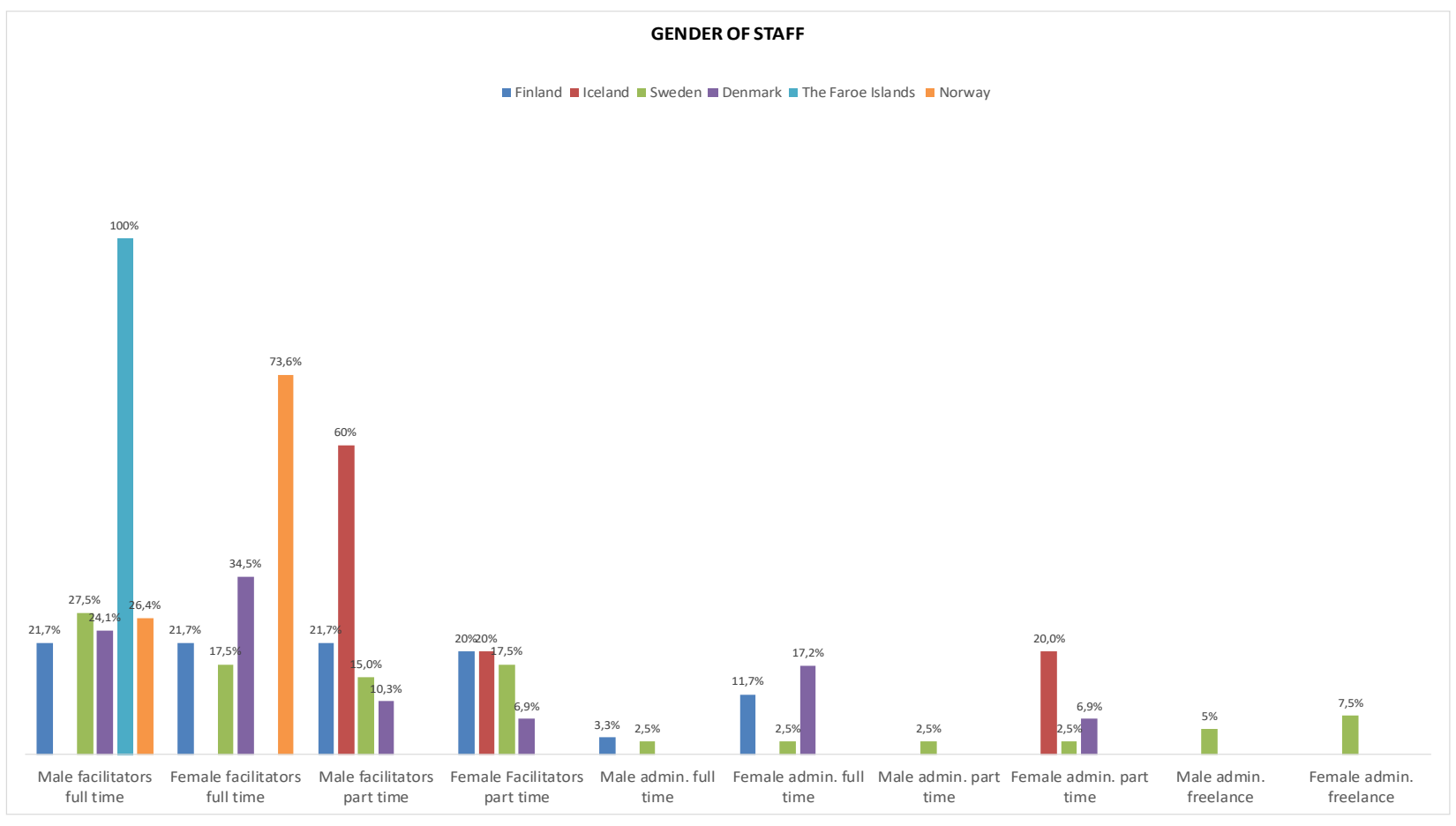




\subsubsection{Qualifications/expertise}

Regarding the qualifications/expertise of the staff, the answers have been weighted according to the total number of staff for each country/territory.

The main professions of the staff in the Nordic countries/territories were psychologists ( $n=70 ; 42.2 \%)$, followed by psychotherapists $(n=49 ; 29.5 \%)$ and social workers $(n=22 ; 13.3 \%)$. No country reported having ex-clients as staff.

Some countries/territories do not follow this exact trend; for example, Sweden reported more social workers $(n=11 ; 42.3 \%)$, and Finland reported more psychotherapists ( $n=25 ; 39.9 \%)$.

Table 8: Staff qualification/expertise

\begin{tabular}{|c|c|c|c|c|c|c|c|c|c|c|c|c|c|c|c|c|}
\hline & \multicolumn{2}{|c|}{ Finland } & \multicolumn{2}{|c|}{ Åland } & \multicolumn{2}{|c|}{ Iceland } & \multicolumn{2}{|c|}{ Sweden } & \multicolumn{2}{|c|}{ Denmark } & \multicolumn{2}{|c|}{$\begin{array}{c}\text { Faroe } \\
\text { Islands }\end{array}$} & \multicolumn{2}{|c|}{ Norway } & \multicolumn{2}{|c|}{ Total } \\
\hline & $\mathbf{F}$ & $\%$ & $\mathbf{F}$ & $\%$ & $\mathbf{F}$ & $\%$ & $\mathbf{F}$ & $\%$ & $\mathbf{F}$ & $\%$ & $\mathbf{F}$ & $\%$ & $\mathbf{F}$ & $\%$ & $F^{*}$ & $\%$ \\
\hline Social workers & 10 & 15.9 & 1 & 50 & & & 11 & 42.3 & & & & & & & 22 & $13 \cdot 3$ \\
\hline Psychotherapists & 25 & 39.7 & & & 4 & 100 & 9 & 34.6 & 2 & 9.1 & & & 9 & 18.8 & 49 & 29.5 \\
\hline Psychologists & 7 & 11.1 & 1 & 50 & & & 4 & 15 & 20 & 90.9 & 1 & 100 & 37 & 77.1 & 70 & 42.2 \\
\hline Mental health workers & 7 & 11.1 & & & & & & & & & & & & & 7 & 4.2 \\
\hline Educators & 2 & 3.2 & & & & & & & & & & & 1 & 2 & 3 & 1.8 \\
\hline \multicolumn{17}{|l|}{ Ex-clients } \\
\hline Others & 12 & 19 & & & & & 2 & $7 \cdot 7$ & & & & & 1 & 2 & 15 & 9 \\
\hline N per country/territory & 63 & & & & 4 & & 26 & & 22 & & 1 & & 48 & & & \\
\hline
\end{tabular}

Note: $\quad \mathrm{N}=166$ (Greenland did not answer to this question).

*Each country/territory could specify the number of workers per dimension. 
Figure 9: Staff qualification/expertise

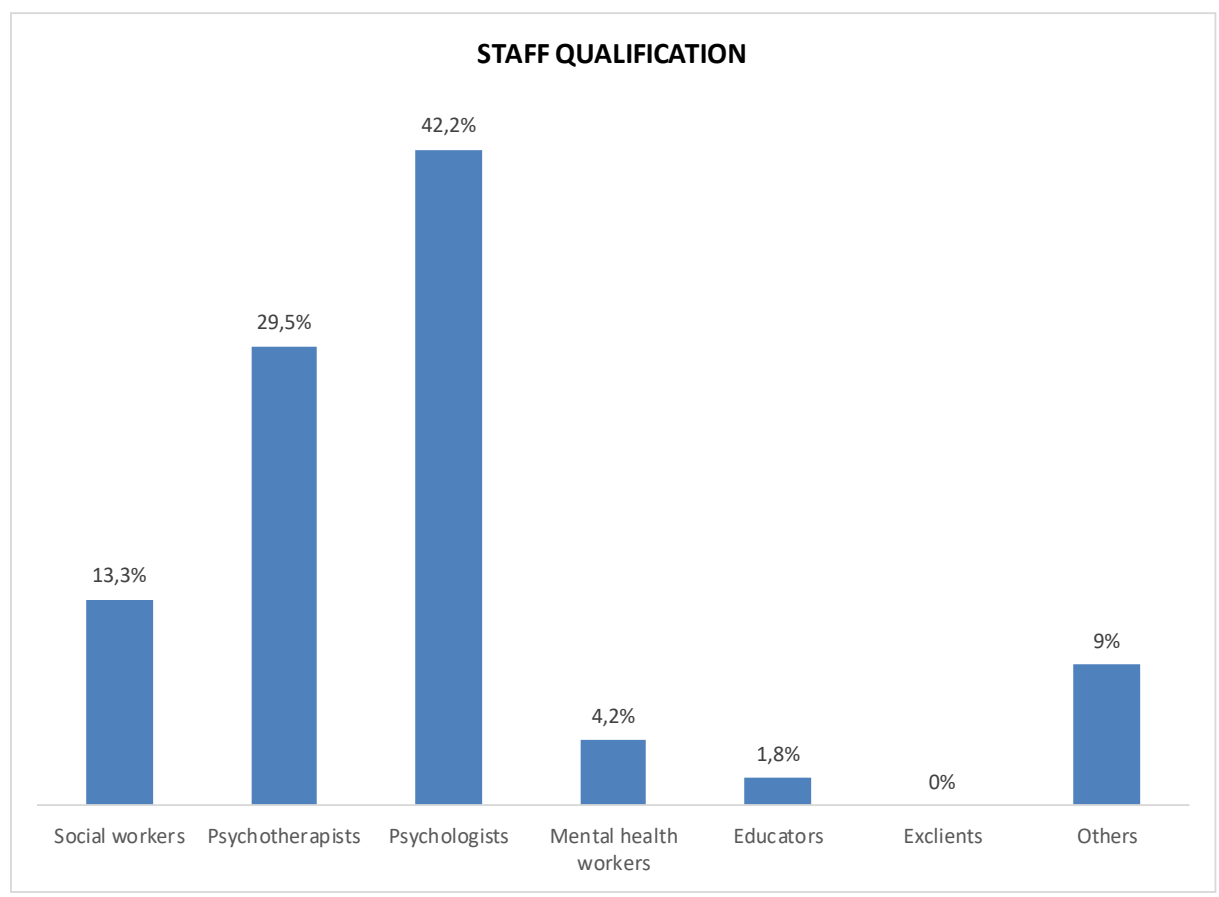

Figure 10: Staff qualifications/expertise

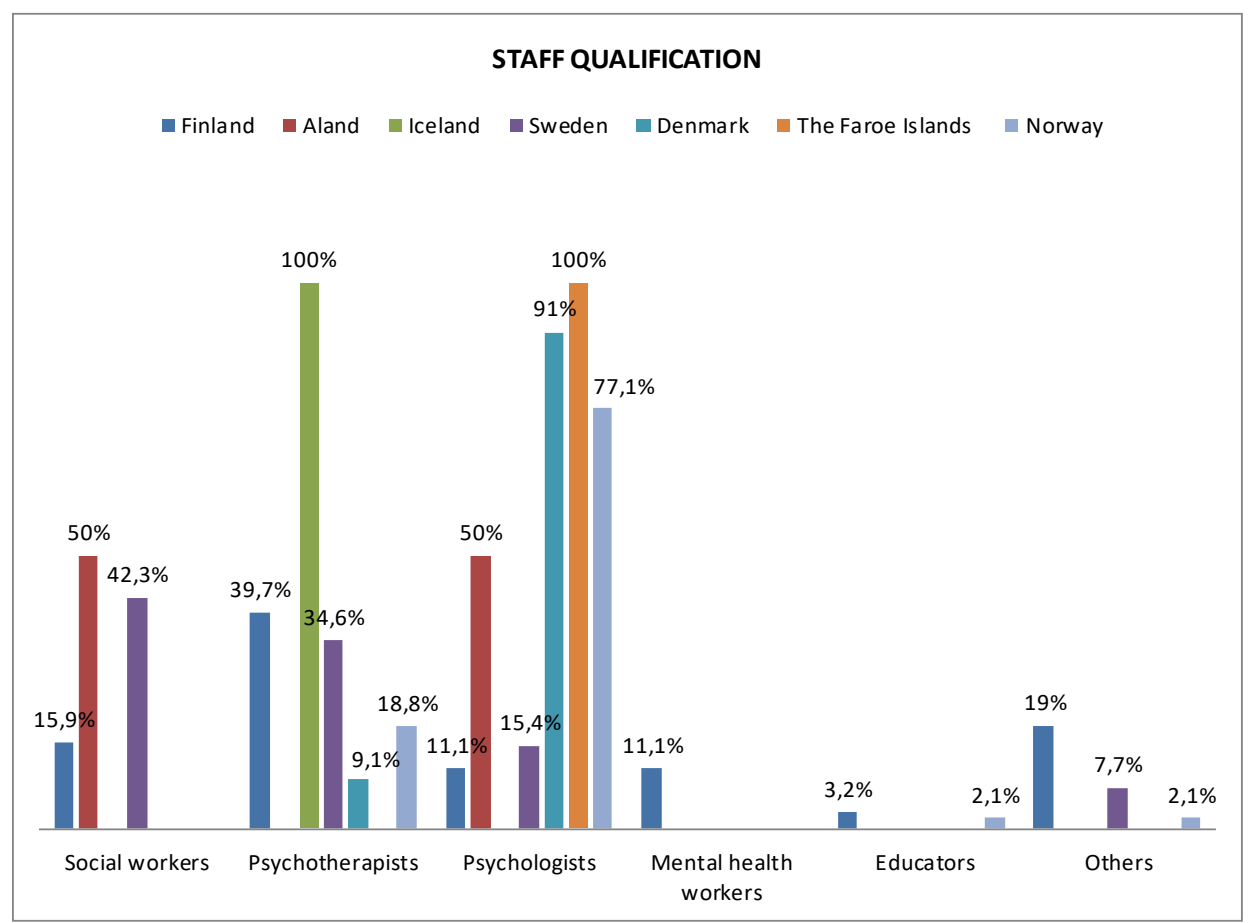




\subsection{Section C: Funding}

\subsubsection{Main sources of funding}

The programmes were mainly financed by municipal funds $(n=24,47.1 \%)$ and government funds $(n=23 ; 45.1 \%)$; regional funding was less represented $(n=7 ; 13.7 \%)$ whereas EU funding was just reported in just one programme $(n=1 ; 2 \%)$.

Further, some programmes received contributions directly from the client $(n=15 ;$ $29.4 \%)$, and a few received private funding ( $n=7 ; 13.7 \%)$.

\begin{tabular}{|c|c|c|c|c|c|c|c|c|c|c|c|c|c|c|c|c|c|c|}
\hline & \multicolumn{2}{|c|}{ Finland } & \multicolumn{2}{|c|}{ Åland } & \multicolumn{2}{|c|}{ Iceland } & \multicolumn{2}{|c|}{ Sweden } & \multicolumn{2}{|c|}{ Denmark } & \multicolumn{2}{|c|}{$\begin{array}{l}\text { Faroe } \\
\text { Islands }\end{array}$} & \multicolumn{2}{|c|}{$\begin{array}{c}\text { Greenlan } \\
\text { d }\end{array}$} & \multicolumn{2}{|c|}{ Norway } & \multicolumn{2}{|c|}{ Total } \\
\hline & $\mathbf{F}$ & $\%$ & $F$ & $\%$ & $\mathbf{F}$ & $\%$ & $\mathbf{F}$ & $\%$ & $\mathbf{F}$ & $\%$ & $\mathbf{F}$ & $\%$ & $\mathbf{F}$ & $\%$ & $\mathbf{F}$ & $\%$ & $F^{*}$ & $\% *$ \\
\hline EU funds & & & 1 & 100 & & & & & & & & & & & & & 1 & 2 \\
\hline Governmental funding & & & 1 & 100 & 1 & 100 & 4 & 23.5 & 3 & 75 & 1 & 100 & 1 & 100 & 12 & 100 & 23 & 45.1 \\
\hline Regional funding & & & & & & & 7 & 41.2 & & & & & & & & & 7 & 13.7 \\
\hline Municipal funding & 1 & 7.1 & & & & & 11 & 64.7 & 1 & 25 & & & & & 11 & 91.7 & 24 & 47.1 \\
\hline Contribution by client & 1 & 7.1 & & & 1 & 100 & 1 & 5.9 & & & & & & & 12 & 100 & 15 & 29.4 \\
\hline $\begin{array}{l}\text { Private Funding } \\
\text { (donations, foundations } \\
\text { etc.) }\end{array}$ & 2 & $14 \cdot 3$ & & & & & 3 & 17.6 & 2 & 50 & & & & & & & 7 & 13.7 \\
\hline Others & 14 & 100 & & & & & & & & & & & & & 11 & 91.7 & 28 & 49 \\
\hline N per country & 14 & & 1 & & 1 & & 17 & & 4 & & 1 & & 1 & & 12 & & & \\
\hline
\end{tabular}

Note: $\quad \mathrm{N}=51$.

*More than one option could be ticked.

Others:

- Finland reported that the non-profit organizations were mainly funded by the Slot Machine Association (RAY) (12 respondents) (and not by the government or municipalities). Two associations reported mixed sources of funding. 


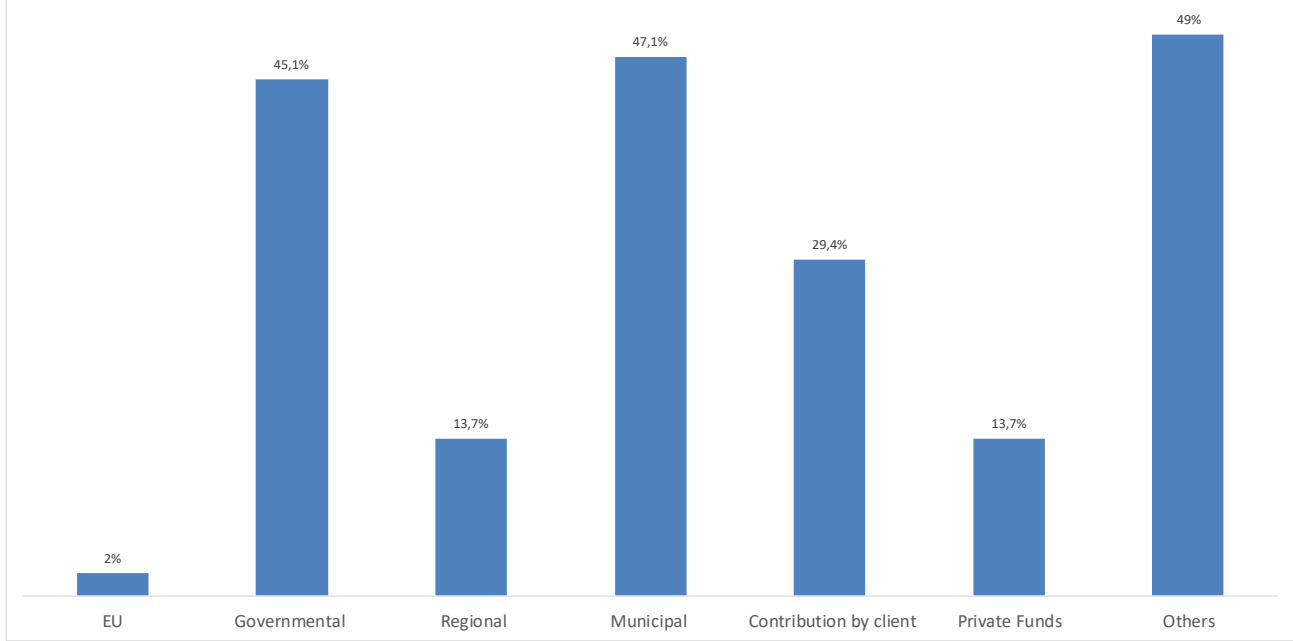

Figure 12: Main sources of funding

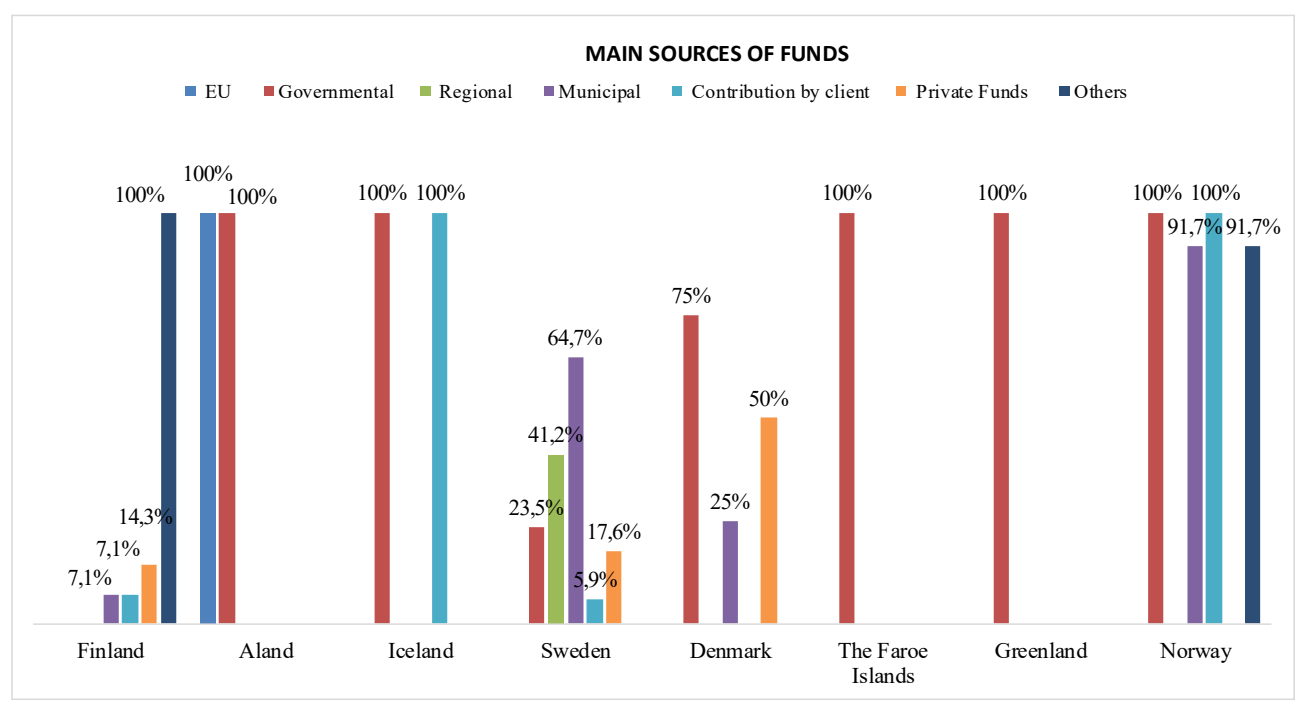

\subsubsection{Types of funding}

The programmes mainly had permanent funding $(n=44 ; 86.3 \%)$. Moreover, some countries/territories reported project-based funding $(n=8 ; 13.7 \%)$. Two of those countries reported solely project-based funding (the Faroe Islands and Greenland), and Denmark reported more project funding $(n=3 ; 75 \%)$ than permanent funding $(n=1 ; 25 \%)$. 
Table 10: Types of funding

\begin{tabular}{|c|c|c|c|c|c|c|c|c|c|c|c|c|c|c|c|c|c|c|}
\hline & \multicolumn{2}{|c|}{ Finland } & \multicolumn{2}{|c|}{ Åland } & \multicolumn{2}{|c|}{ Iceland } & \multicolumn{2}{|c|}{ Sweden } & \multicolumn{2}{|c|}{ Denmark } & \multicolumn{2}{|c|}{$\begin{array}{l}\text { Faroe } \\
\text { Islands }\end{array}$} & \multicolumn{2}{|c|}{ Greenland } & \multicolumn{2}{|c|}{ Norway } & \multicolumn{2}{|c|}{ Total } \\
\hline & $\mathbf{F}$ & $\%$ & $\mathbf{F}$ & $\%$ & $\mathbf{F}$ & $\%$ & $\mathbf{F}$ & $\%$ & F & $\%$ & $\mathrm{~F}$ & $\%$ & $\mathbf{F}$ & $\%$ & F & $\%$ & $\mathbf{F}$ & $\%$ \\
\hline Permanent & 13 & 92.9 & 1 & 100 & 1 & 100 & 16 & 94.1 & 1 & 25 & & & & & 12 & 100 & 44 & 86.3 \\
\hline $\begin{array}{l}\text { Project- } \\
\text { based }\end{array}$ & 1 & 7.1 & & & & & 1 & 5.9 & 3 & 75 & 1 & 100 & 1 & 100 & & & 8 & 13.7 \\
\hline $\begin{array}{l}\mathrm{N} \text { per } \\
\text { country/terri } \\
\text { tory }\end{array}$ & 14 & & 1 & & 1 & & 17 & & 4 & & 1 & & 1 & & 12 & & & \\
\hline
\end{tabular}

Note: $\quad \mathrm{N}=51$.

The programmes were asked to specify the length of the current funding period in the event that it was not permanent:

- Denmark reported that one service provider had private project funding for threeyears, municipal contracts for one-year, state funding for three years and probation service for $3-4$ years. Two other service providers specified that their funding finished in October 2016 (after which their activity will have to cease its ATV services), and finally another service provider reported having funding up to September 2017 (for 2.5 years).

- Norway reported that ATV has funding from the Government and from several municipalities. The state funding is regarded as permanent, even though ATV formally has to send an application for funding to the Government every year. The cooperation with the different municipalities is regulated through written contracts. Some of the contracts are running contracts with a 6 month or 12 months' mutual revocable time frame. Some of the contracts are set for a 3 or $4^{-}$ year period, and then evaluated and renewed.

- Finland also reported applications for funding even if it was stated as permanent.

\subsubsection{Client contributions}

A majority of the programmes do not ask for a contribution from the client ( $n=19$; 57.6\%). A few countries/territories requested a contribution from the client, such as Iceland $(n=1 ; 100 \%)$, and Norway $(n=12 ; 100 \%)$ and to a lesser extent Finland $(n=1 ;$ $7.1 \%)$. 
Table 11: Client contribution

\begin{tabular}{|c|c|c|c|c|c|c|c|c|c|c|c|c|c|c|}
\hline & \multicolumn{2}{|c|}{ Finland } & \multicolumn{2}{|c|}{ Iceland } & \multicolumn{2}{|c|}{ Denmark } & \multicolumn{2}{|c|}{$\begin{array}{l}\text { Faroe } \\
\text { Islands }\end{array}$} & \multicolumn{2}{|c|}{ Greenland } & \multicolumn{2}{|c|}{ Norway } & \multicolumn{2}{|c|}{ Total } \\
\hline & $\mathbf{F}$ & $\%$ & $\mathbf{F}$ & $\%$ & $\mathbf{F}$ & $\%$ & $F$ & $\%$ & $\mathbf{F}$ & $\%$ & $F$ & $\%$ & $F$ & $\%$ \\
\hline No & 13 & 92.9 & & & 4 & 100 & 1 & 100 & 1 & 100 & & & 19 & 57.6 \\
\hline Yes & 1 & 7.1 & 1 & 100 & & & & & & & 12 & 100 & 14 & 42.4 \\
\hline $\begin{array}{l}\mathrm{N} \text { per country } \\
\text { /territory }\end{array}$ & 14 & & 1 & & 4 & & 1 & & 1 & & 12 & & 33 & 100 \\
\hline
\end{tabular}

Note: $\mathrm{N}=33$.

Figure 13: Client contribution

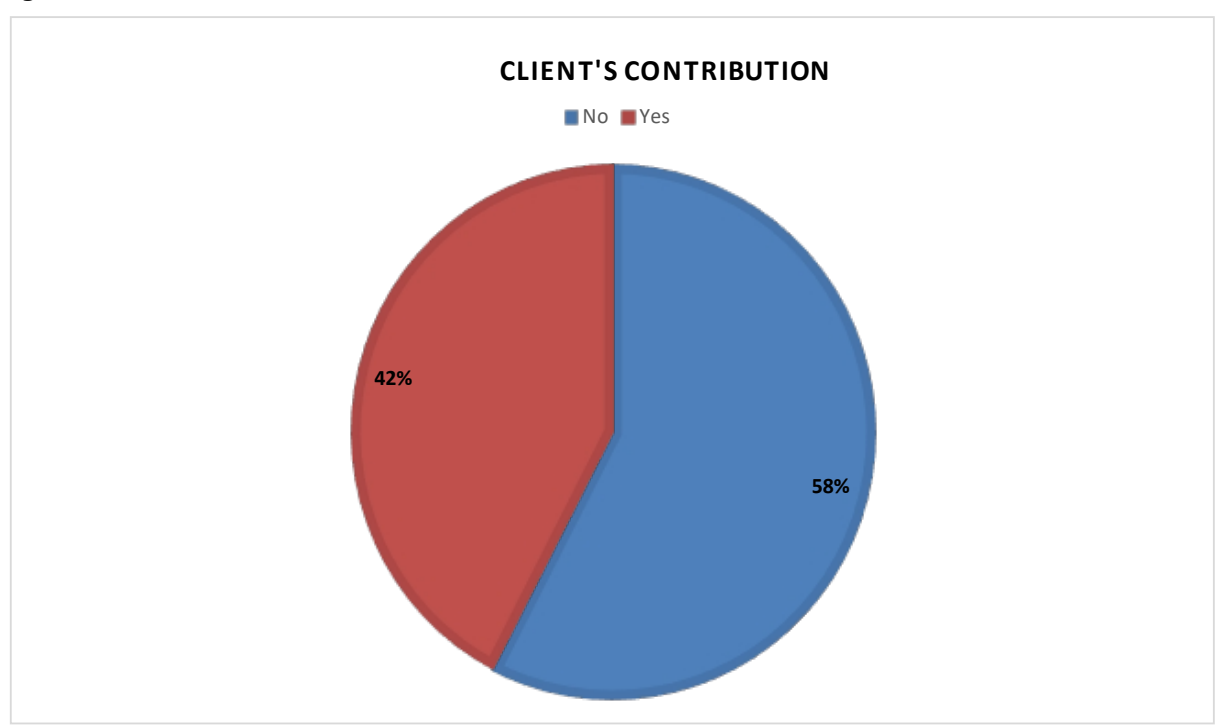

Programmes where asked to specify the amount of contribution that was asked of the client:

- Finland: reported asking for EUR 70 for the whole treatment.

- Iceland: reported asking for EUR 23 per session.

- Norway: reported asking EUR 33 per session and EUR 277 per half-year group sessions (ATV); NOK 350 per session up to NOK 1800, and free of charge thereafter (SBM). 


\subsubsection{Applying for funding}

Programmes where asked how long their funding periods ran for and how much time they spent on applying for funding. Just two countries/territories answered this question. In Finland, most of the service providers receive funding on a yearly basis, whereas in Norway, the ATV ( $n=11$ ) has funding for $3-4$ years.

Denmark was the only country answering the question on how much time is spent on applying for funding: one of their service providers reported that they spent about 850 hours per year.

\subsection{Section D: cooperation and context}

\subsubsection{Collaboration with other institutions / projects}

All the service providers in all the countries/territories reported that they collaborate with other institutions or projects.

The institutions with which they collaborate most were social services $(n=46 ; 92 \%)$, family services $(n=42 ; 84 \%)$, the police $(n=41 ; 82 \%)$, and women's shelters $(n=38 ; 76 \%)$. Institutions with which they collaborated less frequently were the emergency services $(n=1 ; 2 \%)$, the prosecutor $(n=12 ; 28 \%)$, and the civil court $(n=12 ; 28 \%)$, mainly in Sweden and Norway. 
Table 12: Collaboration with other institutions/projects

\begin{tabular}{|c|c|c|c|c|c|c|c|c|c|c|c|c|c|c|c|c|}
\hline & \multicolumn{2}{|c|}{ Finland } & \multicolumn{2}{|c|}{ Iceland } & \multicolumn{2}{|c|}{ Sweden } & \multicolumn{2}{|c|}{ Denmark } & \multicolumn{2}{|c|}{$\begin{array}{l}\text { Faroe } \\
\text { Islands }\end{array}$} & \multicolumn{2}{|c|}{ Greenland } & \multicolumn{2}{|c|}{ Norway } & \multicolumn{2}{|c|}{ Total } \\
\hline & $\mathbf{F}$ & $\%$ & $\mathbf{F}$ & $\%$ & $\mathbf{F}$ & $\%$ & $\mathbf{F}$ & $\%$ & $\mathbf{F}$ & $\%$ & $\mathbf{F}$ & $\%$ & $\mathbf{F}$ & $\%$ & $F^{*}$ & $\%$ * \\
\hline Police & 13 & 92.9 & 1 & 100 & 11 & 64.7 & 3 & 75 & & & 1 & 100 & 12 & 100 & 41 & 82 \\
\hline Criminal court & & & & & 4 & 23.5 & 2 & 50 & 1 & 100 & & & 12 & 100 & 19 & 38 \\
\hline Civil court & & & & & 2 & 11.8 & & & & & & & 12 & 100 & 14 & 28 \\
\hline Prosecutor & & & & & 3 & 17.7 & & & & & & & 11 & 91.7 & 14 & 28 \\
\hline Penal system & 8 & 57.1 & & & 5 & 29.4 & 1 & 25 & & & & & 12 & 100 & 26 & 52 \\
\hline $\begin{array}{l}\text { Youth welfare } \\
\text { office }\end{array}$ & & & & & 7 & 41.2 & & & & & & & 12 & 100 & 19 & 38 \\
\hline $\begin{array}{l}\text { Alcohol } \\
\text { treatment }\end{array}$ & 9 & $64 \cdot 3$ & & & 7 & 41.2 & 1 & 25 & & & & & 12 & 100 & 29 & 58 \\
\hline $\begin{array}{l}\text { Substance } \\
\text { abuse treatment }\end{array}$ & & & & & 5 & 29.4 & 1 & 25 & & & & & 12 & 100 & 18 & 36 \\
\hline Family services & 14 & 100 & 1 & 100 & 13 & 76.5 & 1 & 25 & & & 1 & 100 & 12 & 100 & 42 & 84 \\
\hline $\begin{array}{l}\text { Women's } \\
\text { shelter(s) }\end{array}$ & 11 & 78.6 & 1 & 100 & 12 & 70.6 & 3 & 75 & & & & & 11 & 91.7 & 38 & 76 \\
\hline Hospitals & 8 & 57.1 & & & 7 & 41.2 & & & & & & & 1 & 8.3 & 16 & 32 \\
\hline $\begin{array}{l}\text { General practice } \\
\text { doctors }\end{array}$ & 3 & 21.4 & & & 5 & 29.4 & & & & & & & 12 & 100 & 20 & 40 \\
\hline Emergency units & & & & & 1 & 5.9 & & & & & & & & & 1 & 2 \\
\hline $\begin{array}{l}\text { Women's } \\
\text { counselling } \\
\text { services }\end{array}$ & 7 & 50 & & & 11 & 64.7 & & & & & & & 11 & 91.7 & 29 & 58 \\
\hline Social services & 14 & 100 & 1 & 100 & 16 & 94.1 & 2 & 50 & 1 & 100 & & & 12 & 100 & 46 & 92 \\
\hline Other & 2 & $14 \cdot 3$ & & & 2 & 11.8 & 1 & 25 & & & & & & & 5 & 10 \\
\hline N per country & 14 & & 1 & & 17 & & 4 & & 1 & & 1 & & 12 & & & \\
\hline
\end{tabular}

Note: $\mathrm{N}=50$.

*More than one option could be ticked. 


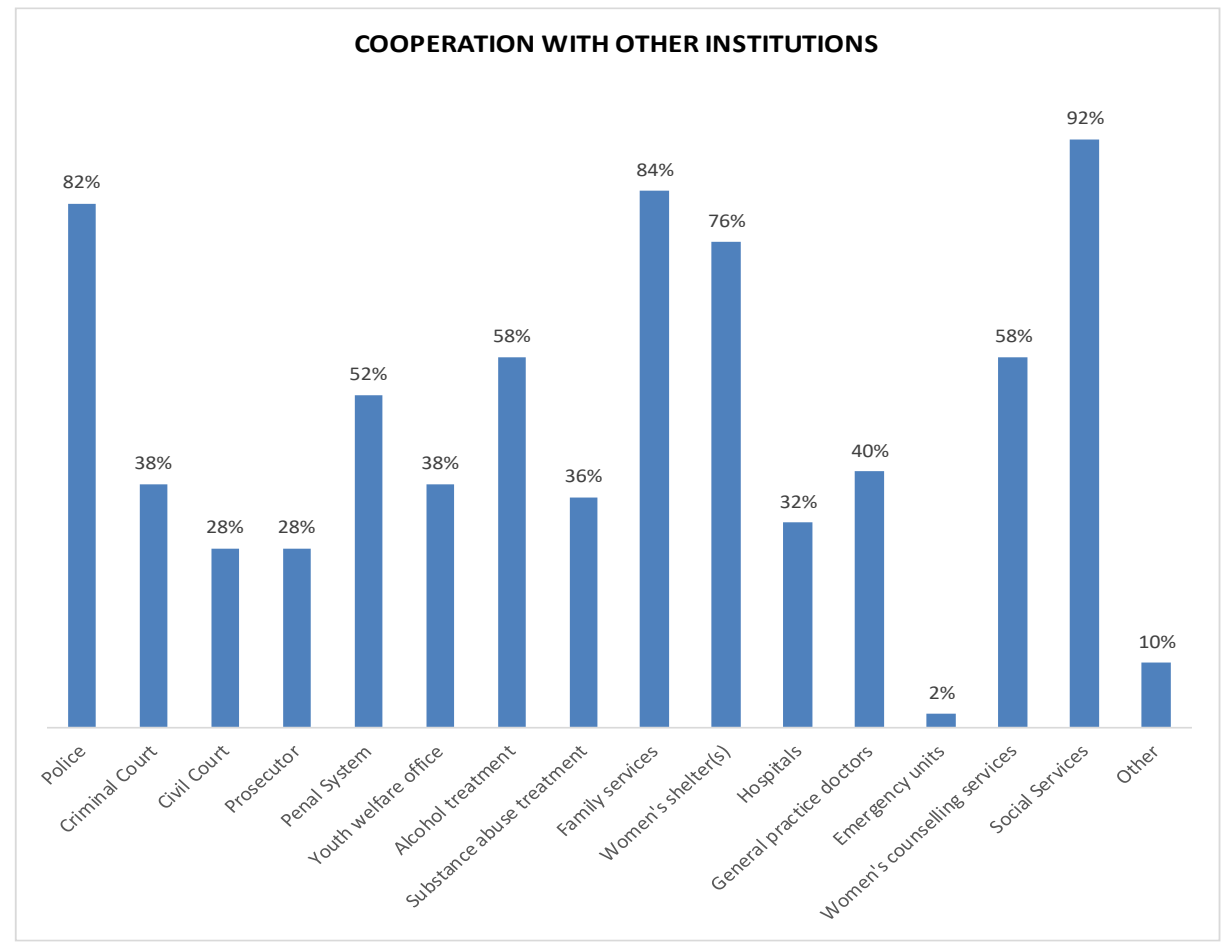

\subsubsection{Inter-institutional alliance against domestic violence}

In four countries, all the service providers reported that their work was part of an interinstitutional alliance against domestic violence (Finland, Iceland, the Faroe Islands and Norway). In Sweden, it was 70\% ( $n=12)$ and in Denmark it was the 25\% $(n=1)$.

Of the programmes that were part of an inter-institutional alliance, more than half were involved on an inter-institutional alliance on a national level $(n=27 ; 66 \%), 46 \%$ were part of an inter-institutional alliance at the local level $(n=19)$, and finally, $12 \%$ reported being part of a regional alliance $(n=5)$. Some reported being part of both a local and national alliance.

Table 13: Inter-institutional alliance

\begin{tabular}{|c|c|c|c|c|c|c|c|c|c|c|c|c|}
\hline & \multicolumn{2}{|c|}{ Finland } & \multicolumn{2}{|c|}{ Iceland } & \multicolumn{2}{|c|}{ Sweden } & \multicolumn{2}{|c|}{$\begin{array}{l}\text { Faroe } \\
\text { Islands }\end{array}$} & \multicolumn{2}{|c|}{ Norway } & \multicolumn{2}{|c|}{ Total } \\
\hline & F & $\%$ & $\mathbf{F}$ & $\%$ & $\mathbf{F}$ & $\%$ & $\mathbf{F}$ & $\%$ & $\mathbf{F}$ & $\%$ & $F^{*}$ & $\% *$ \\
\hline National & 10 & 62.5 & 1 & 100 & 4 & 33.3 & 1 & 100 & 11 & 91.7 & 27 & 66 \\
\hline Regional & 3 & 18.8 & & & 1 & 8.3 & & & 1 & 8.3 & 5 & 12 \\
\hline Local & 3 & 18.8 & & & 5 & 41.7 & & & 11 & 91.7 & 19 & 46 \\
\hline Others & & & & & 2 & 16.7 & & & & & 2 & 5 \\
\hline N per country/territory & 14 & & 1 & & 12 & & 1 & & 12 & & & \\
\hline
\end{tabular}

Source: $\mathrm{N}=41$.

* More than one option could be ticked. 
Figure 15: Inter-institutional alliance

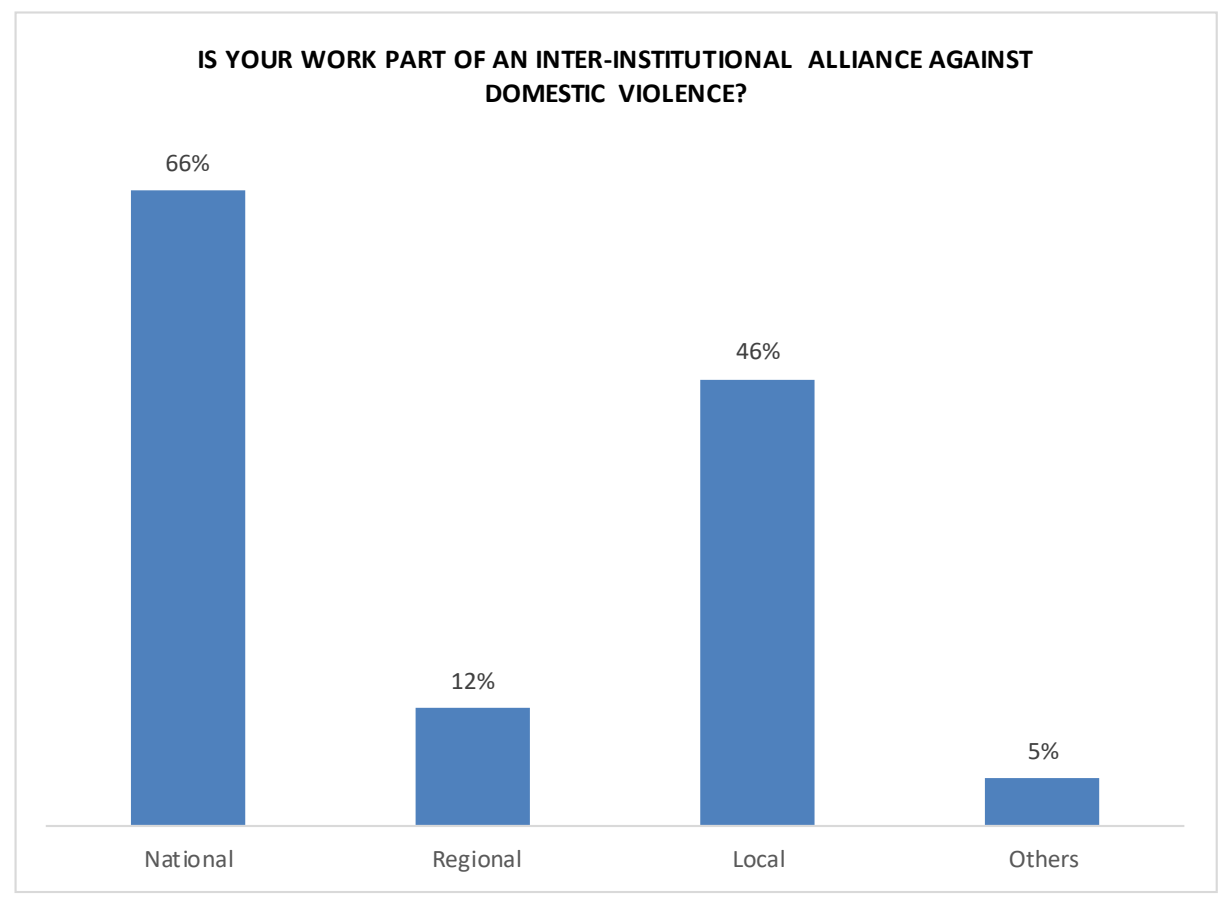

Sweden had two service providers that ticked the option "others", since for one service their inter-institutional alliance was both national and local, and for the other service provider, it was both regional and local.

\subsubsection{Services provided in the field of domestic violence}

As can be seen in Table 14, most of the Nordic countries/territories offer a wide variety of services. The most commonly offered services were for male perpetrators of violence $(n=49 ; 96 \%)$, which is a service offered by nearly all the programmes in all the countries/territories. This was followed by services offered for female perpetrators of violence $(n=42 ; 82.4 \%)$, and same sex perpetrators $(42 ; 82.4 \%)$. Further, support for female $(n=39 ; 76.5 \%)$, and male $(n=40 ; 78.4 \%)$ victims of domestic violence was a common service offered by the programmes. Services for children witnessing violence were offered less often $(n=21 ; 41.2 \%)$, being mostly found in Denmark $(n=3 ; 75 \%)$, Sweden $(n=7 ; 41.2 \%)$, and Greenland $(n=1 ; 100 \%)$. 
Table 14: Services provided

\begin{tabular}{|c|c|c|c|c|c|c|c|c|c|c|c|c|c|c|c|c|c|c|}
\hline & \multicolumn{2}{|c|}{ Finland } & \multicolumn{2}{|c|}{ Åland } & \multicolumn{2}{|c|}{ Iceland } & \multicolumn{2}{|c|}{ Sweden } & \multicolumn{2}{|c|}{ Denmark } & \multicolumn{2}{|c|}{$\begin{array}{l}\text { Faroe } \\
\text { Islands }\end{array}$} & \multicolumn{2}{|c|}{$\begin{array}{c}\text { Greenlan } \\
\quad d\end{array}$} & \multicolumn{2}{|c|}{ Norway } & \multicolumn{2}{|c|}{ Total } \\
\hline & $\mathbf{F}$ & $\%$ & $\mathbf{F}$ & $\%$ & $\mathbf{F}$ & $\%$ & $\mathbf{F}$ & $\%$ & $\mathbf{F}$ & $\%$ & $\mathbf{F}$ & $\%$ & $\mathbf{F}$ & $\%$ & $\mathbf{F}$ & $\%$ & $F^{*}$ & $\% *$ \\
\hline Male perpetrators & 13 & 15.1 & 1 & 100 & 1 & 100 & 17 & 100 & 4 & 100 & 1 & 100 & 1 & 100 & 12 & 100 & 49 & 96 \\
\hline $\begin{array}{l}\text { Female } \\
\text { perpetrators }\end{array}$ & 10 & 11.6 & & & 1 & 100 & 14 & 82.4 & 3 & 75 & 1 & 100 & 1 & 100 & 12 & 100 & 42 & 82.4 \\
\hline $\begin{array}{l}\text { Same sex } \\
\text { perpetrators }\end{array}$ & 13 & 15.1 & & & 1 & 100 & 13 & 76.5 & 1 & 25 & 1 & 100 & 1 & 100 & 12 & 100 & 42 & 82.4 \\
\hline Sexual offenders & 6 & 7.0 & & & & & 5 & 29.4 & & & 1 & 100 & 1 & 100 & 12 & 100 & 25 & 49.0 \\
\hline $\begin{array}{l}\text { Child abuse } \\
\text { offenders }\end{array}$ & 5 & 5.8 & & & & & 8 & 47.1 & 1 & 25 & 1 & 100 & & & 12 & 100 & 27 & 52.9 \\
\hline $\begin{array}{l}\text { Perpetrators of } \\
\text { violence in other } \\
\text { relationships (e.g. } \\
\text { crimes of honour) }\end{array}$ & 10 & 11.6 & & & & & 9 & 52.9 & 1 & 25 & 1 & 100 & & & 12 & 100 & 33 & 64.7 \\
\hline $\begin{array}{l}\text { Other } \\
\text { perpetrators }\end{array}$ & 2 & 2.3 & & & & & 2 & 11.8 & & & & & & & & & 4 & 7.8 \\
\hline $\begin{array}{l}\text { Child witnesses of } \\
\text { violence }\end{array}$ & 7 & 8.1 & & & & & 7 & 41.2 & 3 & 75 & & & 1 & 100 & 3 & 25 & 21 & 41.2 \\
\hline $\begin{array}{l}\text { Support for } \\
\text { female victims of } \\
\text { domestic violence }\end{array}$ & 9 & 10.5 & & & 1 & 100 & 12 & 70.6 & 4 & 100 & & & 1 & 100 & 12 & 100 & 39 & 76.5 \\
\hline $\begin{array}{l}\text { Support for male } \\
\text { victims of } \\
\text { domestic violence }\end{array}$ & 11 & 12.8 & & & 1 & 100 & 13 & 76.5 & 3 & 75 & & & & & 12 & 100 & 40 & 78.4 \\
\hline Others & & & & & & & 2 & 11.8 & 1 & 25 & & & & & 4 & 33.3 & 7 & 14 \\
\hline N per country & 14 & & 1 & & 1 & & 17 & & 4 & & 1 & & 1 & & 12 & & 51 & \\
\hline
\end{tabular}

Note: $\quad \mathrm{N}=51$.

*More than one option could be ticked.

Other services offered were:

- Denmark had one programme for male and female perpetrators of stalking.

- In Norway, three of the ATV offices had funding for the treatment of children. More specifically, ATV provides, to a limited extent, services to adults who use physical or psychological violence against their children. In most cases of "ordinary" violence against partner, when couple have children, it is natural to acknowledge that these children are also exposed to domestic violence, directly or indirectly. In these cases, the treatment service provided by ATV is dealing with this as a part of the treatment work. In the case of sexual offenders, ATV provides services for perpetrators of domestic violence who use sexual violence towards their partners as a part of their abusive behaviour pattern. ATV does not provide services for sexual offenders in the meaning of persons who offends children 
sexually. SBM: has no unit for children, but has "information sessions" with partners exposed to violence.

Figure 16: Services provided

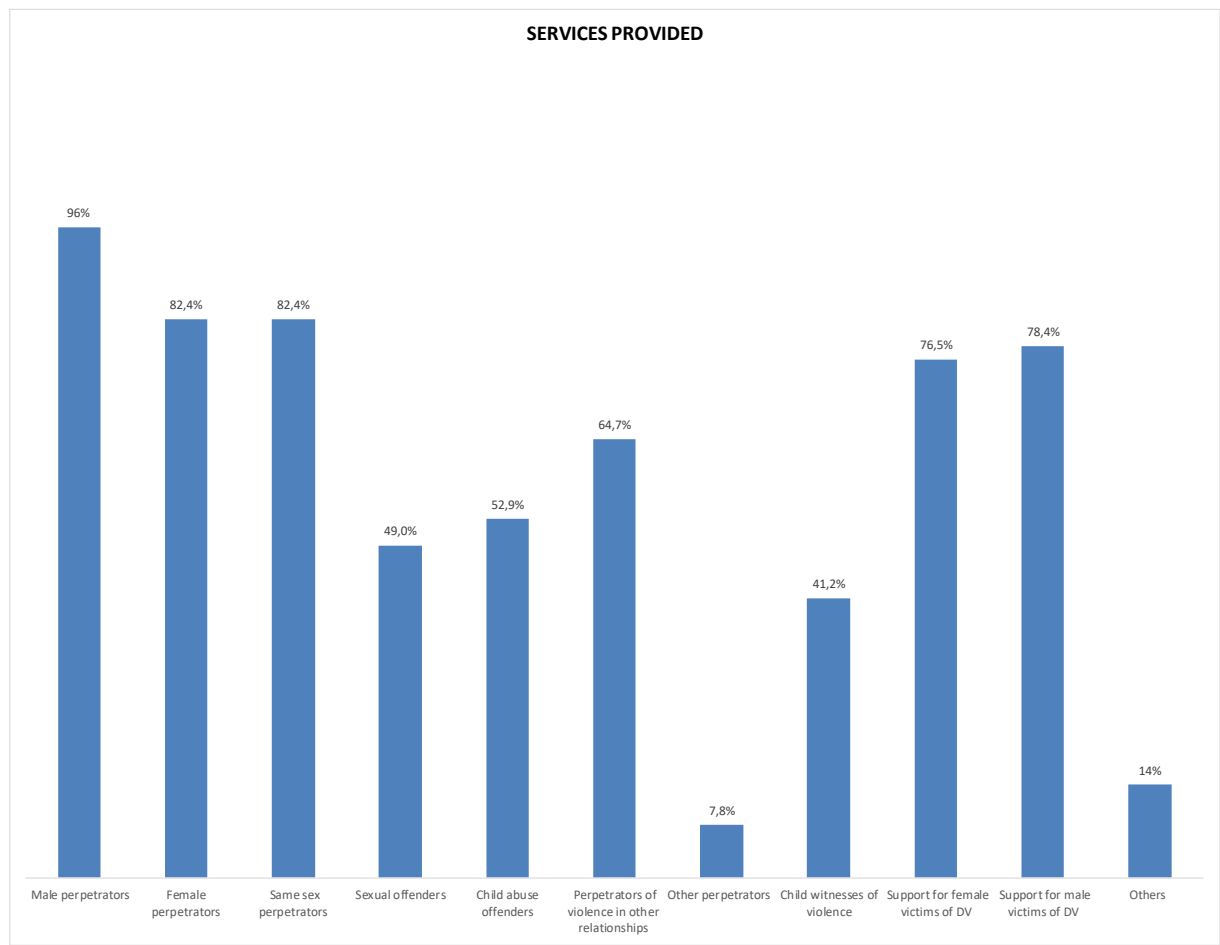

\subsubsection{Referral and intake}

How clients come to attend the programme

The most common method of referral was voluntary self-referral $(n=45 ; 88.2 \%)$. Also, client was often referred by social and welfare agencies $(n=43 ; 84.3 \%)$ and by the police $(n=39 ; 76.5 \%)$. Less often clients were referred by the court/justice system $(n=5 ; 9.8 \%)$, and victim services $(n=21 ; 8.7 \%)$. Finland $(n=1 ; 7.1 \%)$, Sweden $(n=3 ; 17.7 \%)$, and Norway $(n=1 ; 8.3 \%)$ reported some referrals from the court/justice system. Iceland $(n=1 ; 100 \%)$, Sweden $(n=9 ; 52.9 \%)$ and Norway $(n=12 ; 100)$ reported referrals from victim services. Åland and Greenland received only voluntary self-referrals. 
Table 15: Referral to a programme

\begin{tabular}{|c|c|c|c|c|c|c|c|c|c|c|c|c|c|c|c|c|c|c|}
\hline & \multicolumn{2}{|c|}{ Finland } & \multicolumn{2}{|c|}{ Åland } & \multicolumn{2}{|c|}{ Iceland } & \multicolumn{2}{|c|}{ Sweden } & \multicolumn{2}{|c|}{ Denmark } & \multicolumn{2}{|c|}{$\begin{array}{l}\text { Faroe } \\
\text { Islands }\end{array}$} & \multicolumn{2}{|c|}{$\begin{array}{c}\text { Greenlan } \\
\text { d }\end{array}$} & \multicolumn{2}{|c|}{ Norway } & \multicolumn{2}{|c|}{ Total } \\
\hline & $\mathbf{F}$ & $\%$ & $\mathbf{F}$ & $\%$ & $\mathbf{F}$ & $\%$ & $\mathbf{F}$ & $\%$ & $\mathbf{F}$ & $\%$ & $\mathbf{F}$ & $\%$ & $F$ & $\%$ & $\mathbf{F}$ & $\%$ & $F^{*}$ & $\%$ * \\
\hline $\begin{array}{l}\text { Court / Justice } \\
\text { referred }\end{array}$ & 1 & 7.14 & & & & & 3 & 17.7 & & & & & & & 1 & 8.3 & 5 & 9.8 \\
\hline $\begin{array}{l}\text { Voluntarily self- } \\
\text { referred }\end{array}$ & 9 & 64.3 & 1 & 100 & 1 & 100 & 16 & 94.1 & 4 & 100 & 1 & 100 & 1 & 100 & 12 & 100 & 45 & 88.2 \\
\hline $\begin{array}{l}\text { Social and } \\
\text { welfare agencies }\end{array}$ & 10 & 100 & & & 1 & 100 & 16 & 94.1 & 3 & 75 & 1 & 100 & & & 12 & 100 & 43 & 84.3 \\
\hline Police & 10 & 71.4 & & & 1 & 100 & 15 & 88.2 & 1 & 25 & & & & & 12 & 100 & 39 & 76.5 \\
\hline Victim services & & & & & & 100 & 9 & 52.9 & & & & & & & 12 & 100 & 21 & 8.7 \\
\hline $\begin{array}{l}\text { Child protection } \\
\text { services }\end{array}$ & 10 & 71.4 & & & & & 13 & 76.5 & & & & & & & 12 & 100 & 35 & 68.6 \\
\hline $\begin{array}{l}\text { Alcohol and } \\
\text { substance abuse } \\
\text { treatment }\end{array}$ & & & & & 1 & 100 & 12 & 70.6 & & & & & & & 12 & 100 & 25 & 49 \\
\hline Other & 10 & 71.4 & & & & & 6 & $35 \cdot 3$ & & & & & & & 12 & 100 & 28 & 54.9 \\
\hline $\begin{array}{l}\text { N per country } \\
\text { /territory }\end{array}$ & 14 & & 1 & & 1 & & 17 & & 4 & & 1 & & 1 & & 12 & & & \\
\hline
\end{tabular}

Note: $\mathrm{N}=51$

*More than one option could be ticked.

Most of the "other" referral agencies were (corresponding number and country/territory that proposed it in brackets): local parishes (1), and mental health services (1) (Finland), and psychiatric services (2), general practice doctors (2) (Norway)

\section{Proportion of clients referred}

Finland reported nine service providers with clients mostly from self-referral, two $50 \%$ self-referral and $50 \%$ referred by other institutions, and the rest reported having clients mainly referred by other institutions.

In Sweden nine service providers reported that at least $50 \%$ of the clients were voluntary self-referrals.

In Denmark two service providers reported that $50 \%$ of the clients were recommended by other institutions and 50\% were voluntary self-referrals. Another service provider reported that $20 \%$ of clients were referred by other institutions and $80 \%$ were self-referrals, while the last service provider reported that $30 \%$ of clients were referred by other institutions and 70 were self-referrals.

The Faroe Islands reported that $30 \%$ of clients were referred by other institutions and $70 \%$ were self-referrals. Finally, Norway reported that $10 \%$ of the clients were referred by court justice (SBM). The other service providers (11 from ATV) reported that $50 \%$ of the clients were referred by other institutions and $50 \%$ were self-referrals.

Åland did not answer this question and Greenland still does not have clients. 


\section{Intake requirement}

Regarding intake requirements, all the service providers from Iceland, Sweden and Norway reported intake requirements. In Finland $78.6 \%$ of the service providers reported some intake requirements $(n=11)$, whereas $21.4 \%(n=3)$ reported not having any. The Faroe Islands does not have intake requirements and in Greenland they are still to be decided.

\section{Intake requirements of the programmes}

The most often mentioned intake requirements were "be alcohol and drug free during participation" ( $n=37 ; 80.4 \%)$, "demonstrate a minimum of motivation to participate in the programme" $(n=29 ; 63 \%)$, and "be able to cognitively follow the programme" $(n=28 ; 60.9 \%)$.

\section{Table 16: Intake requirements}

\begin{tabular}{|c|c|c|c|c|c|c|c|c|c|c|c|c|c|c|}
\hline & \multicolumn{2}{|c|}{ Finland } & \multicolumn{2}{|c|}{ Åland } & \multicolumn{2}{|c|}{ Iceland } & \multicolumn{2}{|c|}{ Sweden } & \multicolumn{2}{|c|}{ Denmark } & \multicolumn{2}{|c|}{ Norway } & \multicolumn{2}{|c|}{ Total } \\
\hline & $F$ & $\%$ & F & $\%$ & $\mathbf{F}$ & $\%$ & $\mathbf{F}$ & $\%$ & F & $\%$ & $\mathbf{F}$ & $\%$ & $F^{*}$ & $\% *$ \\
\hline $\begin{array}{l}\text { Sign an agreement / contract as a basis } \\
\text { for programme participation }\end{array}$ & & & 1 & 100 & & & 3 & $17 \cdot 7$ & 2 & 50 & 12 & 100 & 18 & 39.1 \\
\hline $\begin{array}{l}\text { Demonstrate a minimum of } \\
\text { accountability for his abuse }\end{array}$ & & & & & 1 & 100 & 8 & 47.1 & 3 & 75 & 12 & 100 & 24 & 52.2 \\
\hline $\begin{array}{l}\text { Demonstrate a minimum of } \\
\text { motivation to participate in the measure }\end{array}$ & 4 & 36.4 & & & 1 & 100 & 9 & 52.9 & 3 & 75 & 12 & 100 & 29 & 63 \\
\hline $\begin{array}{l}\text { Be able to cognitively follow the } \\
\text { programme }\end{array}$ & 3 & $27 \cdot 3$ & & & 1 & 100 & 10 & 58.8 & 2 & 50 & 12 & 100 & 28 & 60.9 \\
\hline $\begin{array}{l}\text { Have a good enough knowledge of } \\
\text { language to follow the content of work }\end{array}$ & 3 & $27 \cdot 3$ & & & & & 7 & 41.9 & 2 & 50 & 12 & 100 & 24 & 52.2 \\
\hline $\begin{array}{l}\text { Fulfil the facilitator's requirements for } \\
\text { group work }\end{array}$ & 3 & $27 \cdot 3$ & & & & & 9 & 52.9 & & & 12 & 100 & 24 & 52.2 \\
\hline $\begin{array}{l}\text { Agree to a limited confidentiality (e.g. } \\
\text { against partner, referring institutions) }\end{array}$ & 5 & $45 \cdot 4$ & & & 1 & 100 & 6 & $35 \cdot 3$ & 1 & 25 & 12 & 100 & 25 & $54 \cdot 3$ \\
\hline $\begin{array}{l}\text { Give permission for facilitators to } \\
\text { contact the partner }\end{array}$ & 3 & $27 \cdot 3$ & & & 1 & 100 & 7 & 41.2 & 2 & 50 & 11 & 91.7 & 24 & 52.2 \\
\hline $\begin{array}{l}\text { Be alcohol and drug free during } \\
\text { participation }\end{array}$ & 9 & 81.8 & & & 1 & 100 & 12 & 70.6 & 3 & 75 & 12 & 100 & 37 & 80.4 \\
\hline $\begin{array}{l}\text { Be unaffected by severe mental } \\
\text { disorders }\end{array}$ & & & & & & & 10 & 58.8 & 3 & 75 & 12 & 100 & 25 & $54 \cdot 3$ \\
\hline Others & & & & & & & & & 1 & 25 & & & 1 & 2.2 \\
\hline $\mathrm{N}$ per country/territory & 11 & & & & 1 & & 17 & & 4 & & 12 & & 259 & \\
\hline
\end{tabular}

Note: $\quad \mathrm{N}=46$.

* More than one option could be ticked. 


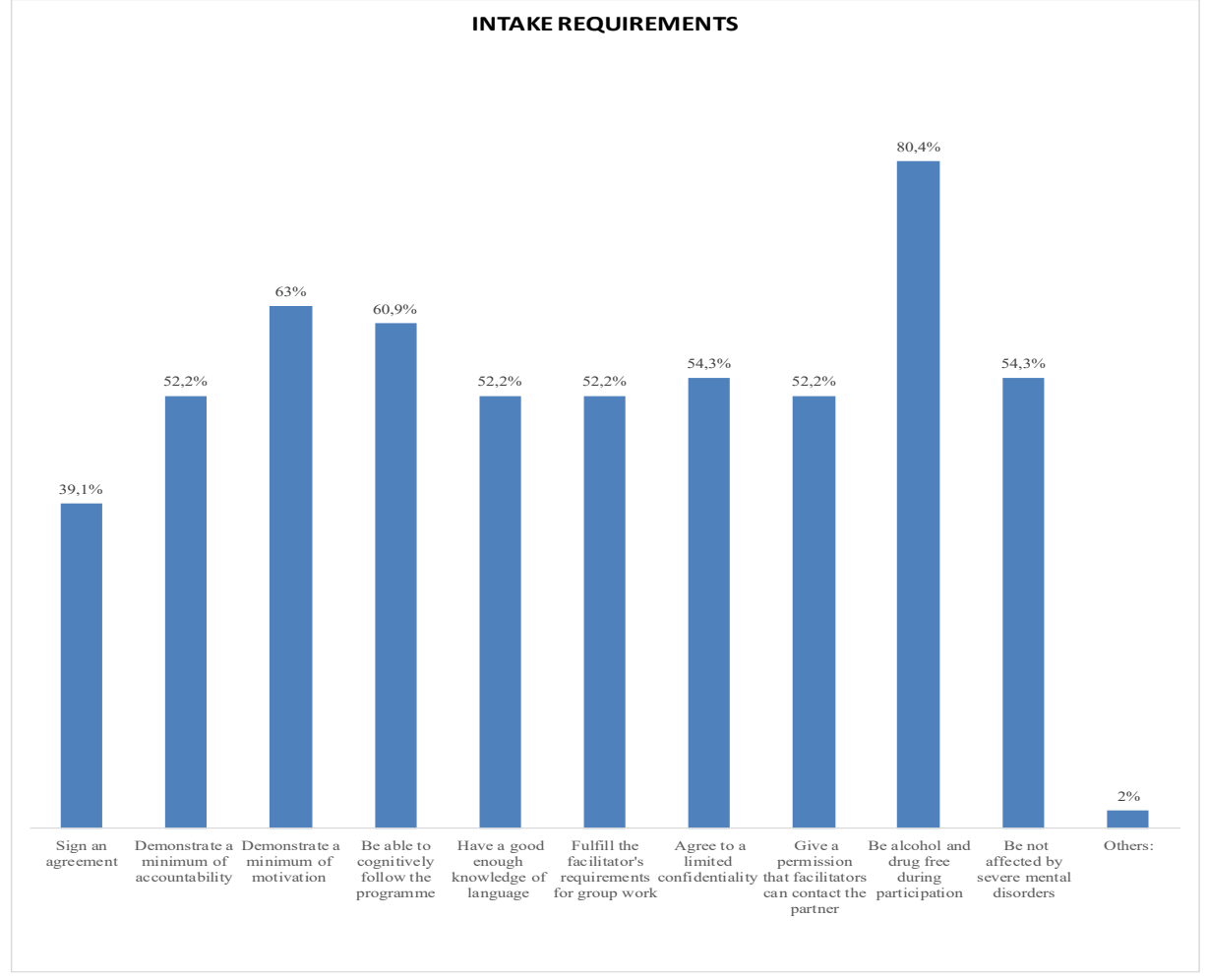

Reponses to the "others" option, one service provider reported that the use of alcohol or drugs must not interfere with treatment (Denmark).

Intake/ clearing phase

Most of the programmes $(n=25 ; 69 \%)$ offer an individual counselling phase before the group work, whereas a few just ask for an individual interview $(n=8 ; 22 \%)$. Sweden and the Faroe Islands had some programmes that did not have any intake/clearing phase. In Finland, and Norway (Åland too) all the programmes reported an individual counselling phase as a clearing phase before the group work.

Table 17: Intake/clearing phase

\begin{tabular}{|c|c|c|c|c|c|c|c|c|c|c|c|c|c|c|}
\hline & \multicolumn{2}{|c|}{ Iceland } & \multicolumn{2}{|c|}{ Åland } & \multicolumn{2}{|c|}{ Sweden } & \multicolumn{2}{|c|}{ Denmark } & \multicolumn{2}{|c|}{$\begin{array}{l}\text { Faroe } \\
\text { Islands }\end{array}$} & \multicolumn{2}{|c|}{ Norway } & \multicolumn{2}{|c|}{ Total } \\
\hline & $\mathbf{F}$ & $\%$ & $\mathbf{F}$ & $\%$ & $\mathbf{F}$ & $\%$ & $F$ & $\%$ & $F$ & $\%$ & $F$ & $\%$ & $\mathbf{F}$ & $\%$ \\
\hline No & & & & & 2 & 11.8 & & & 1 & 100 & & & 3 & 8 \\
\hline Only initial interview & & & & & 5 & 29.4 & 3 & 75 & & & & & 8 & 22 \\
\hline $\begin{array}{l}\text { Individual counselling } \\
\text { phase before group work }\end{array}$ & 1 & 100 & 1 & 100 & 10 & 58.8 & 1 & 25 & & & 12 & 100 & 25 & 69 \\
\hline N per country & 1 & & 1 & & 17 & & 4 & & 1 & & 12 & & & 100 \\
\hline
\end{tabular}

Note: $\quad \mathrm{N}=36$. 


\section{Exclusion criteria}

Most of the programmes $(n=39 ; 88.7 \%)$ had some criteria for exclusion.

Table 18: Presence of criteria for exclusion

\begin{tabular}{|c|c|c|c|c|c|c|c|c|c|c|c|c|c|c|}
\hline & \multicolumn{2}{|c|}{ Finland } & \multicolumn{2}{|c|}{ Iceland } & \multicolumn{2}{|c|}{ Sweden } & \multicolumn{2}{|c|}{ Denmark } & \multicolumn{2}{|c|}{ Faroe Islands } & \multicolumn{2}{|c|}{ Norway } & \multicolumn{2}{|c|}{ Total } \\
\hline & $\mathbf{F}$ & $\%$ & $\mathbf{F}$ & $\%$ & $\mathbf{F}$ & $\%$ & $\mathbf{F}$ & $\%$ & $\mathbf{F}$ & $\%$ & $\mathbf{F}$ & $\%$ & $\mathbf{F}$ & $\%$ \\
\hline No & 4 & 28.6 & & & & & & & 1 & 100 & & & 5 & 11.4 \\
\hline Yes & 10 & & 1 & 100 & 12 & 70.6 & 4 & 100 & & & 12 & 100 & 39 & 88.7 \\
\hline N per country & 14 & & 1 & & 12 & & 4 & & 1 & & 12 & & & 100 \\
\hline
\end{tabular}

Note: $\quad \mathrm{N}=44$.

The programmes that reported having some criteria for exclusion $(n=39)$ were asked to specify the criteria for exclusion.

The most often mentioned criteria (see Table 18) for excluding the clients from treatment was that he/she has been violent against group members or facilitators $(n=34 ; 87.2 \%)$, followed by the fact that the client has continued to be abusive toward his partner/ex-partner $(n=20 ; 51.3 \%)$.

\section{Table 19: Exclusion criteria}

\begin{tabular}{|c|c|c|c|c|c|c|c|c|c|c|c|c|}
\hline & \multicolumn{2}{|c|}{ Finland } & \multicolumn{2}{|c|}{ Iceland } & \multicolumn{2}{|c|}{ Sweden } & \multicolumn{2}{|c|}{ Denmark } & \multicolumn{2}{|c|}{ Norway } & \multicolumn{2}{|c|}{ Total } \\
\hline & $\mathbf{F}$ & $\%$ & $\mathbf{F}$ & $\%$ & $\mathbf{F}$ & $\%$ & $\mathbf{F}$ & $\%$ & $\mathbf{F}$ & $\%$ & $F^{*}$ & $\% *$ \\
\hline $\begin{array}{l}\text { Continues to be abusive toward his } \\
\text { partner/ex-partner }\end{array}$ & & & & & 6 & $35 \cdot 3$ & 2 & 50 & 12 & 100 & 20 & 51.3 \\
\hline $\begin{array}{l}\text { Is violent against group members or } \\
\text { facilitators }\end{array}$ & 9 & 64.3 & 1 & 100 & 11 & 64.7 & 2 & 50 & 11 & 91.7 & 34 & 87.2 \\
\hline Breaks the agreement/contract & 1 & 7.1 & & & 8 & 47.1 & & & & & 9 & 23.1 \\
\hline Does not pay the fees & & & & & & & 2 & 75 & 12 & 100 & 15 & 38.5 \\
\hline $\begin{array}{l}\text { Demonstrates a lack of participation / } \\
\text { cooperation }\end{array}$ & 6 & 42.9 & & & 10 & 58.8 & & & & & 16 & 41 \\
\hline $\begin{array}{l}\text { Is absent without permission from } \\
\text { measure more than } X X X\end{array}$ & 4 & 28.6 & & & 8 & 47.1 & & & & & 14 & 35.9 \\
\hline $\begin{array}{l}\text { Is absent with a valid excuse from } \\
\text { measure more_than } X X X \text { times }\end{array}$ & & & & & 1 & 5.9 & & & & & 1 & 2.6 \\
\hline Others & & & & & 1 & 5.9 & & & & & 1 & 2.6 \\
\hline $\mathrm{N}$ per country/territory & 10 & & 1 & & 12 & & 4 & & 12 & & & \\
\hline
\end{tabular}

Note: $\quad \mathrm{N}=39$.

*More than one option could be ticked.

In the "Others" option one service provider reported that if the client does not agree to partner contact, this might also be an exclusion criteria (Sweden) 


\section{Risk assessment}

More than half of the programmes $(n=30 ; 60 \%)$ use some risk-assessment instrument, but quite a lot of programmes still do not use them $(n=20 ; 40 \%)$. In Norway and Iceland all the programmes $(n=12 ; n=1$ respectively) reported assessment instruments, whereas in Finland, Sweden, and Denmark, around half of the programmes $(n=8 ; n=8 ; n=2$ respectively) do not use risk-assessment instruments (in the Faroe Islands and Greenland, none of the programmes use them $n=1$ )

Table 20: Risk-assessment instruments

\begin{tabular}{|c|c|c|c|c|c|c|c|c|c|c|c|c|c|c|c|c|}
\hline & \multicolumn{2}{|c|}{ Finland } & \multicolumn{2}{|c|}{ Iceland } & \multicolumn{2}{|c|}{ Sweden } & \multicolumn{2}{|c|}{ Denmark } & \multicolumn{2}{|c|}{$\begin{array}{l}\text { Faroe } \\
\text { Islands }\end{array}$} & \multicolumn{2}{|c|}{ Greenland } & \multicolumn{2}{|c|}{ Norway } & \multicolumn{2}{|c|}{ Total } \\
\hline & $F$ & $\%$ & $\mathbf{F}$ & $\%$ & $\mathbf{F}$ & $\%$ & $F$ & $\%$ & $F$ & $\%$ & $\mathbf{F}$ & $\%$ & $\mathbf{F}$ & $\%$ & F & $\%$ \\
\hline No & 8 & 57.1 & & & 8 & 47.1 & 2 & 50 & 1 & 100 & 1 & 100 & & & 20 & 40 \\
\hline Yes & 6 & 42.9 & 1 & 100 & 9 & 52.9 & 2 & 50 & & & & & 12 & 100 & 30 & 60 \\
\hline $\begin{array}{l}\mathrm{N} \text { per country } \\
\text { /territory }\end{array}$ & 14 & & 1 & & 17 & & 4 & & 1 & & 1 & & 12 & & & 100 \\
\hline
\end{tabular}

Note: $\quad \mathrm{N}=50$.

Figure 18: Risk-assessment instruments

USE OF RISK ASSESSMENT INSTRUMENTS № $\mathrm{N}$ res

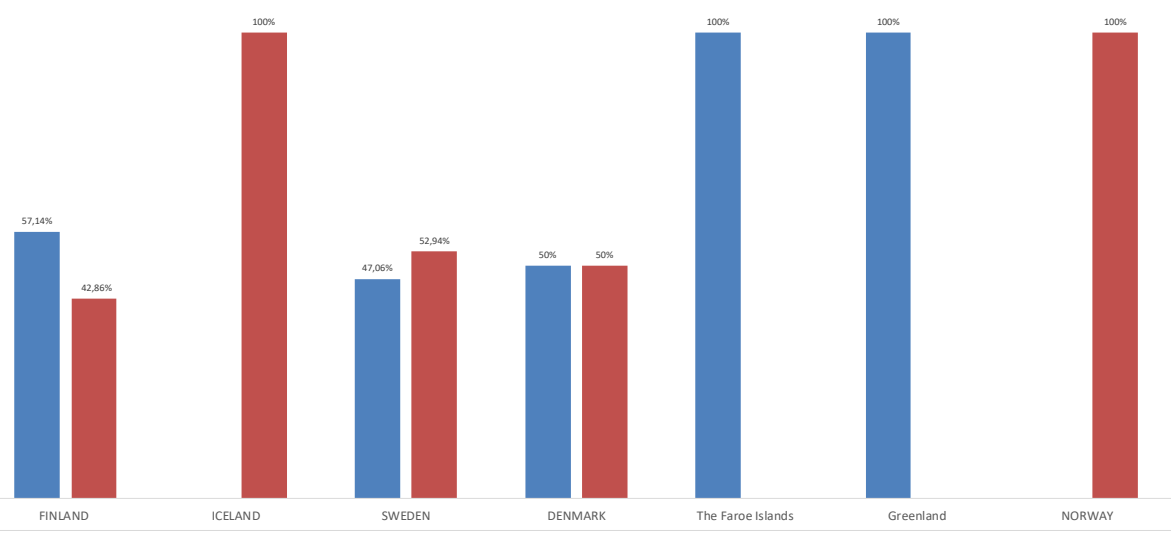

Service providers were asked to specify what kind of instruments they use, in the event that they reported that they used an instrument. The most mentioned instruments were:

- MARAK-form, CTS2, self-developed violence mapping form or a questionnaire (Finland).

- ATV's spousal abuse risk assessment (Iceland and Norway).

- FREDA (based on the international risk assessment Danger Assessment).

- Spousal Assault Risk Assessment Guide (SARA). (Sweden, Denmark, and Norway). 
- PATRIARK (used to assess risk of honour-based violence) (Sweden).

- Stalking Assessment and Management (SAM, for assessing risk of stalking behaviour) (Sweden and Denmark).

- $\quad$ Stalking Risk Profile (SRP) (Denmark).

- Screening Assessment for Stalking and Harassment (SASH) (Denmark).

- SBM mapping (Norway).

- Norway also specified that risk assessment is done at the beginning of the treatment, during the treatment and at the end. Moreover, partner contact is part of the risk assessment.

\section{Ethnic Minorities}

The question of whether a specific perpetrator program is provided for ethnic minorities was answered by Iceland, Sweden, and Norway. The two first countries did not provide any specific programme. Norway was the sole country providing a specific program (all the 11 service providers from ATV).

\subsubsection{Methodology and framework of activity}

\section{Concept of treatment}

When asked whether they worked according to established concepts or a specific model of perpetrator treatment, more than half of the service providers reported working according to a specific model $(75.5 \% ; n=37)$, while the rest did not.

In Iceland and Norway all the service providers reported working according to a model. Finland reported a different trend, with more than half of the programmes $(n=8$; $57.1 \%)$ reported not working according to any specific model. Finally, in the Faroe Islands the sole service provider in the territory reported not working according to any specific model.

\begin{tabular}{|c|c|c|c|c|c|c|c|c|c|c|c|c|c|c|}
\hline & \multicolumn{2}{|c|}{ Finland } & \multicolumn{2}{|c|}{ Iceland } & \multicolumn{2}{|c|}{ Sweden } & \multicolumn{2}{|c|}{ Denmark } & \multicolumn{2}{|c|}{$\begin{array}{l}\text { Faroe } \\
\text { Islands }\end{array}$} & \multicolumn{2}{|c|}{ Norway } & \multicolumn{2}{|c|}{ Total } \\
\hline & $\mathbf{F}$ & $\%$ & $\mathbf{F}$ & $\%$ & F & $\%$ & $\mathbf{F}$ & $\%$ & $\mathbf{F}$ & $\%$ & $\mathbf{F}$ & $\%$ & F & $\%$ \\
\hline No & 8 & 57.1 & & & 2 & 11.8 & 1 & 25 & 1 & 100 & & & 12 & 24.5 \\
\hline Yes & 6 & 42.9 & 1 & 100 & 15 & 88.2 & 3 & 75 & & & 12 & 100 & 37 & 75.5 \\
\hline $\begin{array}{l}\text { N per } \\
\text { countryl } \\
\text { territory }\end{array}$ & 14 & & 1 & & 17 & & 4 & & 1 & & 12 & & & 100 \\
\hline
\end{tabular}

Note: $\quad \mathrm{N}=49$. 


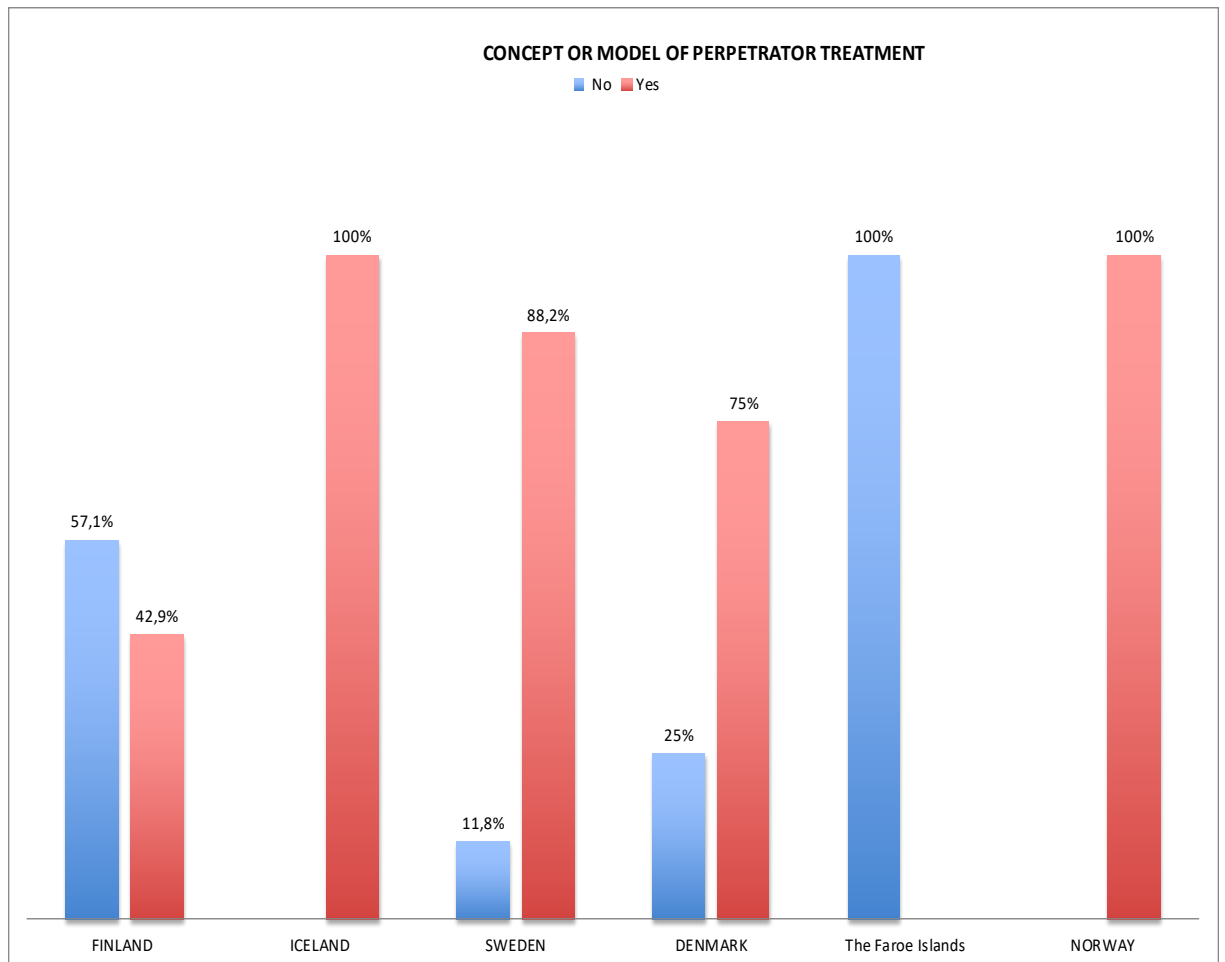

Service providers that reported working to a specific model were asked to specify which model:

- Finland reported six service providers that worked according to an integrated working method, psychodynamic conceptions of human behaviour and theory of inner script dynamics, traumatherapy, acceptance and commitment therapy and dialogical practices. One service provider reported working according to its own model. The different service providers reported different working methods even if they belonged to an umbrella organization.

- Iceland: the sole service provider reported working according to the ATV's treatment guidelines.

- Sweden: had $13(77 \%)$ service providers that reported either partly or completely working based on the established model of ATV. Another service provider reported working according to psychodynamic therapy and cognitive behavioural therapy (CBT).

- Denmark: One service provider reported working according to cognitive behaviour therapy (CBT) and social training, a systemic approach and family therapy, a psychodynamic approach, psychoeducation and a constructive and narrative approach. In individual counselling CBT, mindfulness and mentalization 
was used, while couples counselling was used using IMAGO couples therapy and Emotional Focused Therapy (EFT).

- Norway reported that the ATV-offices ( $n=11$ ) worked according to a specific model of ATV for the treatment of adults using violence. Whereas SBM ( $n=1)$ worked according to a specific model developed by Brøset, based in Cognitive Behavioural Therapy (CBT), for the treatment of adults using violence.

\section{Approaches to treatment}

As shown in Table 22, the most common approach followed in the Nordic countries was the "cognitive behavioural therapy/ (social) training" ( $n=37 ; 74 \%)$, followed by the "psychodynamic approach" ( $n=35 ; 70 \%)$ and "psychoeducational" $(n=31 ; 62 \%)$. The less often followed approaches appeared to be the "constructivist and narrative" ( $n=24 ;$ $48 \%)$, and the "systemic approach / family therapy" $(n=25 ; 50 \%)$. However, they are still indicated as approaches used by nearly half of service providers. Thus, there seems to be a wide variety of methods used, which tend to be combined differently in each country/territory and programme.

Table 22: Approaches to treatment

\begin{tabular}{|c|c|c|c|c|c|c|c|c|c|c|c|c|c|c|c|c|}
\hline & \multicolumn{2}{|c|}{ Finland } & \multicolumn{2}{|c|}{ Åland } & \multicolumn{2}{|c|}{ Iceland } & \multicolumn{2}{|c|}{ Sweden } & \multicolumn{2}{|c|}{ Denmark } & \multicolumn{2}{|c|}{$\begin{array}{l}\text { Faroe } \\
\text { Islands }\end{array}$} & \multicolumn{2}{|c|}{ Norway } & \multicolumn{2}{|c|}{ Total } \\
\hline & $\mathbf{F}$ & $\%$ & $\mathbf{F}$ & $\%$ & $F$ & $\%$ & $\mathbf{F}$ & $\%$ & $\mathbf{F}$ & $\%$ & $\mathbf{F}$ & $\%$ & $\mathbf{F}$ & $\%$ & $\mathbf{F}$ & $\%$ \\
\hline $\begin{array}{l}\text { Cognitive behaviour } \\
\text { therapy/ (social) training }\end{array}$ & 10 & 71.4 & & & 1 & 100 & 10 & 58.8 & 4 & 100 & & & 12 & 100 & 37 & 74 \\
\hline $\begin{array}{l}\text { Systemic approach / } \\
\text { family therapy }\end{array}$ & 5 & 35.7 & & & & & 6 & $35 \cdot 3$ & 3 & 75 & & & 11 & 91.7 & 25 & 50 \\
\hline $\begin{array}{l}\text { Psychodynamic } \\
\text { approach }\end{array}$ & 6 & 42.9 & 1 & 100 & 1 & 100 & 10 & 58.8 & 4 & 100 & 1 & 100 & 12 & 100 & 35 & 70 \\
\hline $\begin{array}{l}\text { Gender specific/ } \\
\text { feministic approach }\end{array}$ & 8 & 57.1 & 1 & 100 & & & 6 & $35 \cdot 3$ & 1 & 25 & & & 11 & 91.7 & 27 & 54 \\
\hline Psychoeducational & 6 & 42.9 & 1 & 100 & 1 & 100 & 9 & 52.9 & 3 & 75 & & & 11 & 91.7 & 31 & 62 \\
\hline $\begin{array}{l}\text { Constructivist and } \\
\text { narrative }\end{array}$ & 4 & 28.6 & & & 1 & 100 & 5 & 29.4 & 3 & 75 & & & 11 & 91.7 & 24 & 48 \\
\hline Other approaches & 3 & 21.4 & & & & & 5 & 29.4 & 3 & 75 & & & & & 11 & 22 \\
\hline $\mathrm{N}$ per country/territory & 14 & & & & 1 & & 17 & & 4 & & 1 & & 12 & & & \\
\hline
\end{tabular}

Note: $\mathrm{N}=50$.

* More than one option could be ticked. 


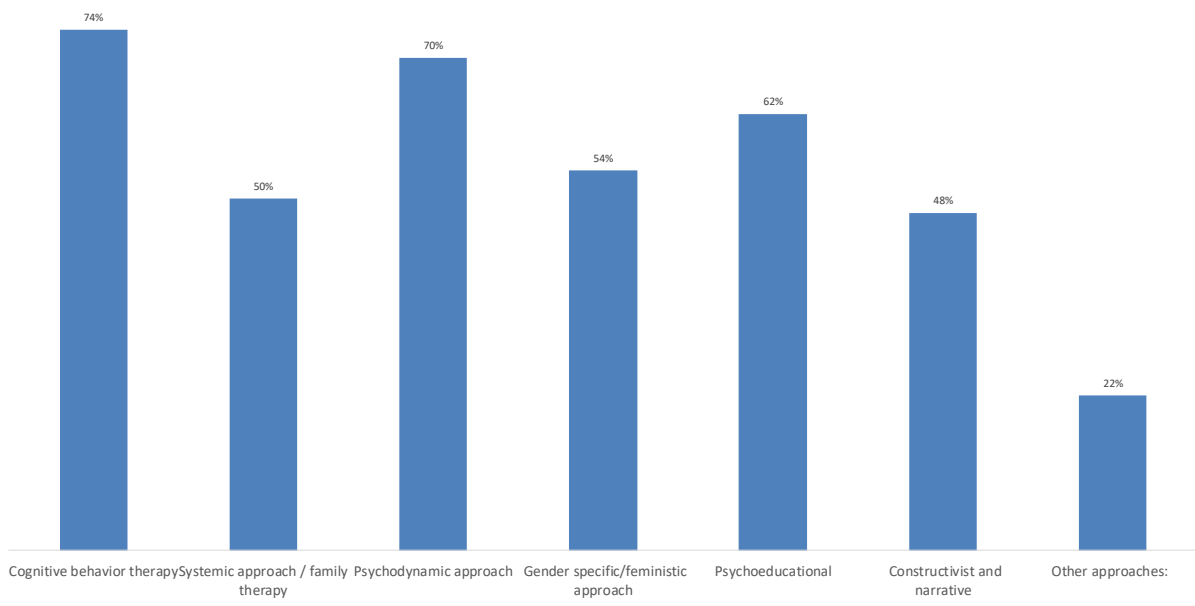

Regarding the "Other" approaches mentioned by the programmes they can be listed as follows:

- Finland: Two service providers reported using integrative therapy, and another the discursive method.

- Sweden: Five service providers reported working based on attachment therapy, compassion-focused therapy, the circle of security, transactional analysis and an integrative combination of approaches.

- Denmark: One service provider reported working using mindfulness and mentalization, while couples counselling employed IMAGO couples therapy and emotional focused therapy (EFT). Another service provider reported working according to the phenomenological approach, and another one according to a mindfulness approach.

- Norway: 11 (ATV) also followed trauma-specific methods.

\section{Intervention modality}

As can be seen in Table 23, the most common treatment modality is individual counselling $(n=50 ; 98 \%)$, followed by group work $(n=38 ; 74.5 \%)$, and finally couples counselling $(n=31 ; 60.8 \%)$. Couples counselling is especially present in Norway ( $n=11$; $91.7 \%)$ and Finland $n=12 ; 85.7 \%)$. 
Table 23: Intervention modality

\begin{tabular}{|c|c|c|c|c|c|c|c|c|c|c|c|c|c|c|c|c|c|c|}
\hline & \multicolumn{2}{|c|}{ Finland } & \multicolumn{2}{|c|}{ Åland } & \multicolumn{2}{|c|}{ Iceland } & \multicolumn{2}{|c|}{ Sweden } & \multicolumn{2}{|c|}{ Denmark } & \multicolumn{2}{|c|}{$\begin{array}{c}\text { Faroe } \\
\text { Islands }\end{array}$} & \multicolumn{2}{|c|}{$\begin{array}{c}\text { Greenlan } \\
\text { d }\end{array}$} & \multicolumn{2}{|c|}{ Norway } & \multicolumn{2}{|c|}{ Total } \\
\hline & $\mathbf{F}$ & $\%$ & $\mathbf{F}$ & $\%$ & $\mathbf{F}$ & $\%$ & $\mathbf{F}$ & $\%$ & $\mathbf{F}$ & $\%$ & $\mathbf{F}$ & $\%$ & $\mathbf{F}$ & $\%$ & $\mathbf{F}$ & $\%$ & $F^{*}$ & $\%$ * \\
\hline Group work & 11 & 78.6 & 1 & 100 & 1 & 100 & 11 & 64.7 & 2 & 50 & & & & & 12 & 100 & 38 & 74.5 \\
\hline $\begin{array}{l}\text { Individual } \\
\text { Counselling }\end{array}$ & 14 & 100 & 1 & 100 & 1 & 100 & 17 & 100 & 4 & 100 & 1 & 100 & 1 & 100 & 11 & 91.7 & 50 & 98 \\
\hline $\begin{array}{l}\text { Couple } \\
\text { counselling }\end{array}$ & 12 & 85.7 & & & & & 4 & $23 \cdot 5$ & 3 & 75 & & & $1 * *$ & 100 & 11 & 91.7 & 31 & 60.8 \\
\hline N per country & 14 & & 1 & & 1 & & 17 & & 4 & & 1 & & 1 & & 12 & & & \\
\hline
\end{tabular}

Note: $\mathrm{N}=51$

*More than one option could be ticked.

** Plans to offer couples work in the future, the other questions referring to couples work were not answered by Greenland.

Figure 21: Intervention modality

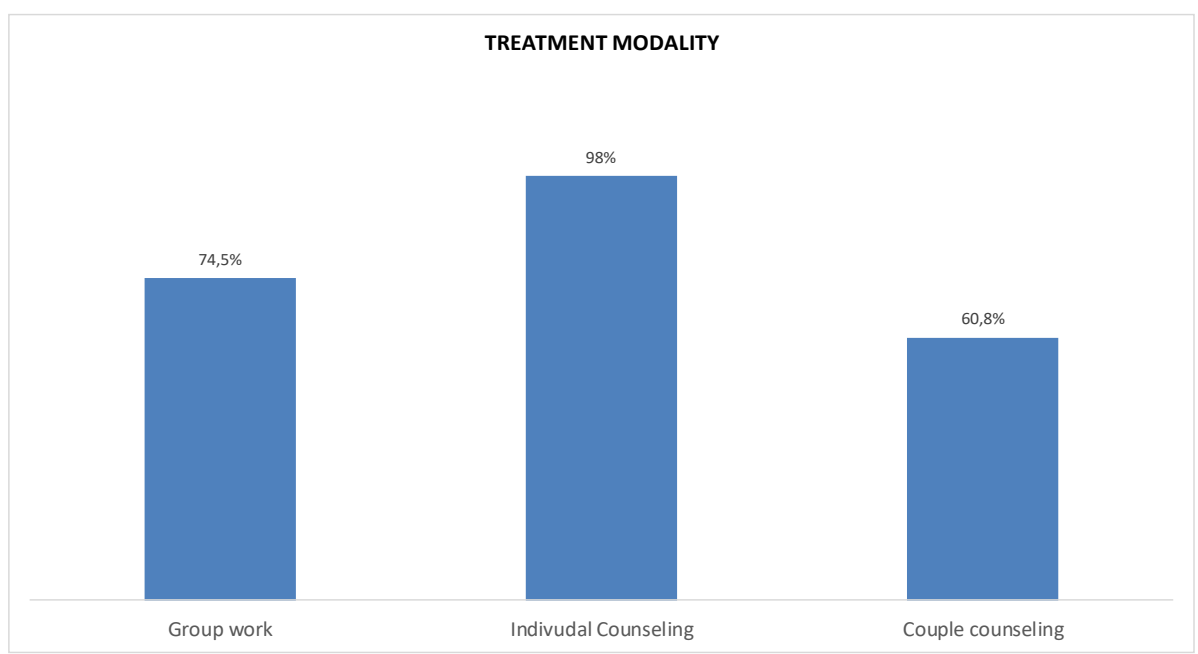

Figure 22: Intervention modality

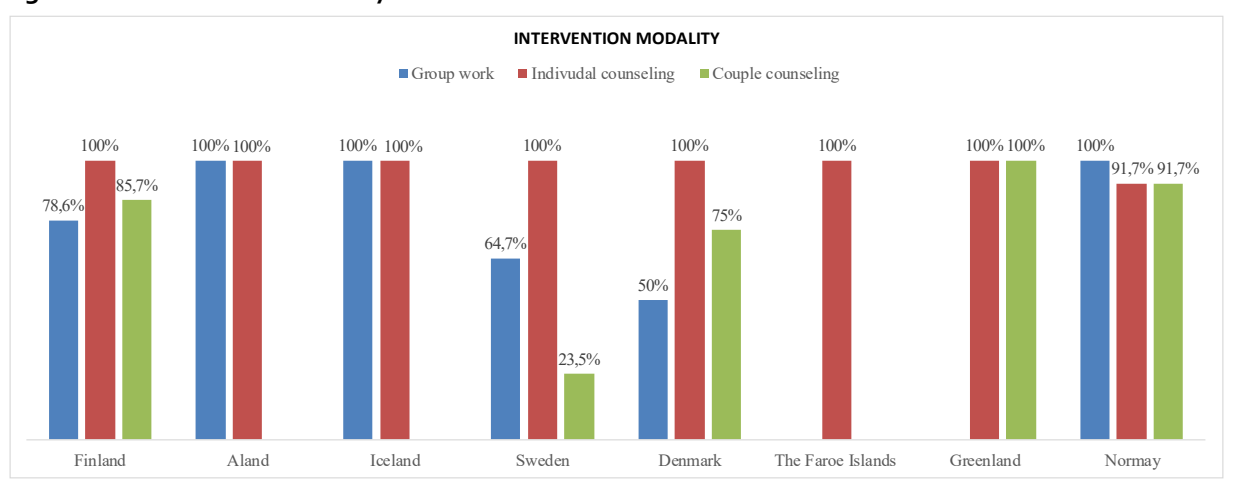




\subsubsection{Group work}

\section{Group work and facilitators}

Service providers offering group work $(n=38)$ were asked about the gender of the facilitators. Group work takes place with the following facilitators (see Table 24): mostly mixed teams $(n=17 ; 68 \%)$, followed by male teams $(n=15 ; 60 \%)$, and female team $(n=14 ;$ $56 \%)$.

Table 24: Gender of the group facilitators

\begin{tabular}{|c|c|c|c|c|c|c|c|c|}
\hline & \multicolumn{2}{|c|}{ Sweden } & \multicolumn{2}{|c|}{ Denmark } & \multicolumn{2}{|c|}{ Norway } & \multicolumn{2}{|c|}{ Total } \\
\hline & $\mathbf{F}$ & $\%$ & $\mathbf{F}$ & $\%$ & $\mathbf{F}$ & $\%$ & $F^{*}$ & $\% *$ \\
\hline One Facilitator Male & & & & & & & 0 & \\
\hline One Facilitator Female & 1 & 9.1 & & & & & 1 & 4 \\
\hline Male team & 3 & $27 \cdot 3$ & 1 & 50 & 11 & 91.7 & 15 & 60 \\
\hline Female Team & 2 & 18.2 & 1 & 50 & 11 & 91.7 & 14 & 56 \\
\hline Mixed Team & 3 & $27 \cdot 3$ & 2 & 100 & 12 & 100 & 17 & 68 \\
\hline N per country & 11 & & 2 & & 12 & & & \\
\hline
\end{tabular}

Note: $\quad \mathrm{N}=25$

*More than one option could be ticked.

\subsubsection{Framework for group work}

\section{Group modality}

Service providers offering group work $(n=38)$ were asked about the framework of their work. It was reported that $50 \%(n=13)$ of the facilities that have group work have open rolling groups, whereas $38.5 \%(n=10)$ have open groups. In Denmark, one service provider specified that open groups are for children and the closed ones are for adult perpetrators.

Table 25: Group modality

\begin{tabular}{|c|c|c|c|c|c|c|c|c|c|c|}
\hline & \multicolumn{2}{|c|}{ Iceland } & \multicolumn{2}{|c|}{ Sweden } & \multicolumn{2}{|c|}{ Denmark } & \multicolumn{2}{|c|}{ Norway } & \multicolumn{2}{|c|}{ Total } \\
\hline & $\mathbf{F}$ & $\%$ & $\mathbf{F}$ & $\%$ & $\mathbf{F}$ & $\%$ & $\mathbf{F}$ & $\%$ & $\mathbf{F}$ & $\%$ \\
\hline Open Rolling Groups & 1 & 100 & 8 & 72.7 & 1 & 50 & & & 10 & 38.5 \\
\hline Closed Groups & & & 1 & 9.1 & 1 & 50 & 11 & 91.7 & 13 & 50 \\
\hline Both & & & 2 & 18.2 & & & 1 & 8.3 & 3 & 11.5 \\
\hline $\mathrm{N}$ per country/territory & 1 & & 11 & & 2 & & 12 & & & 100 \\
\hline
\end{tabular}

Note: $\quad \mathrm{N}=26$

\subsubsection{Frequency of group sessions}

Service providers that offered group work $(n=38)$ were asked about the frequency of group sessions. Of the programmes that answered this question $(n=26)$, all had group sessions on a weekly basis. 


\subsubsection{Duration of sessions}

Regarding duration of single sessions, most of the respondents ( $n=21 ; 56.8 \%)$ reported that the group sessions were of a two-hour duration, the second most common duration was an hour and a half $(n=11 ; 29.7 \%)$.

Table 26: Duration of group work sessions

\begin{tabular}{|c|c|c|c|c|c|c|c|c|c|c|c|c|}
\hline \multirow[b]{2}{*}{ Hours } & \multicolumn{2}{|c|}{ Finland } & \multicolumn{2}{|c|}{ Iceland } & \multicolumn{2}{|c|}{ Sweden } & \multicolumn{2}{|c|}{ Denmark } & \multicolumn{2}{|c|}{ Norway } & \multicolumn{2}{|c|}{ Total } \\
\hline & $\mathbf{F}$ & $\%$ & F & $\%$ & F & $\%$ & $\mathbf{F}$ & $\%$ & $\mathbf{F}$ & $\%$ & F & $\%$ \\
\hline 1 & & & & & 1 & 9.1 & & & & & 1 & 2.7 \\
\hline 1.5 & 5 & $45 \cdot 5$ & 1 & 100 & 5 & $45 \cdot 5$ & & & & & 11 & 29.7 \\
\hline 1.75 & 2 & 18.2 & & & & & & & & & 2 & 5.4 \\
\hline 2 & 4 & 36.4 & & & 3 & 27.3 & 2 & 100 & 12 & 100 & 21 & 56.8 \\
\hline 2.5 & & & & & 1 & 9.1 & & & & & 1 & 2.7 \\
\hline 5 & & & & & 1 & 9.1 & & & & & 1 & 2.7 \\
\hline N per country & 11 & & 1 & & 11 & & 2 & & 12 & & 37 & 100 \\
\hline
\end{tabular}

Note: $\quad \mathrm{N}=37$.

\section{Hours for group sessions}

Service providers that reporting offering group work $(n=38)$ were asked about the total hours for the entire group treatment.

In terms of hours for group treatment, three countries answered this question: In Finland $(n=11$ ) the group treatment had an averaging of 20 hours (ranging from 7.5 to 26.25 hours), Sweden ( $n=6)$ presented an averaging of 50 hours (ranging from 30 to 90 hours, with $50 \%$ between 30 and 40 hours) and in Denmark ( $n=1$ ) the length was 40 hours.

\subsubsection{Duration of group work}

Service providers that offered group work $(n=38)$ were asked about the duration of group work.

All the responses fell into the range of either " 14 to 26 weeks" ( $n=19 ; 51.4 \%$ ), or " 27 to 52 weeks" $(n=18 ; 48.7 \%)$. One, out of the two service providers that offer group work in Denmark, indicated a duration of " 14 up to 26 weeks" (the other service provider that offers group work did not indicate its duration). In Iceland, they indicated a duration of " 27 to 52 weeks". Norway was split approximately half and half between those two dimensions. 
Table 27: Duration of group work

\begin{tabular}{|c|c|c|c|c|c|c|c|c|c|c|}
\hline & \multicolumn{2}{|c|}{ Iceland } & \multicolumn{2}{|c|}{ Sweden } & \multicolumn{2}{|c|}{ Denmark } & \multicolumn{2}{|c|}{ Norway } & \multicolumn{2}{|c|}{ Total } \\
\hline & $\mathbf{F}$ & $\%$ & $\mathbf{F}$ & $\%$ & $\mathbf{F}$ & $\%$ & $\mathbf{F}$ & $\%$ & $\mathbf{F}$ & $\%$ \\
\hline Up to 13 weeks & & & & & & & & & 0 & 0 \\
\hline 14 to 26 weeks & & & 6 & 54.5 & 1 & 50 & 12 & 100 & 19 & 51.4 \\
\hline 27 to 52 weeks & 1 & 100 & 5 & $45 \cdot 4$ & & & 12 & 100 & 18 & 48.7 \\
\hline N per country/territory & 1 & & 11 & & 2 & & 12 & & 37 & 100 \\
\hline
\end{tabular}

Note: $\quad \mathrm{N}=37$.

\subsubsection{Number of participants in group work}

Service providers that reported offering group work $(n=38)$ were asked about the average number of participants in each group work. The most common number of participants was from 6 to $10(n=24 ; 63.2 \%)$. No programme reported groups of more than 10 participants.

Table 28: Average number of participants

\begin{tabular}{|c|c|c|c|c|c|c|c|c|c|c|c|c|c|c|}
\hline & \multicolumn{2}{|c|}{ Finland } & \multicolumn{2}{|c|}{ Åland } & \multicolumn{2}{|c|}{ Iceland } & \multicolumn{2}{|c|}{ Sweden } & \multicolumn{2}{|c|}{ Denmark } & \multicolumn{2}{|c|}{ Norway } & \multicolumn{2}{|c|}{ Total } \\
\hline & $\mathbf{F}$ & $\%$ & $\mathbf{F}$ & $\%$ & $\mathbf{F}$ & $\%$ & $\mathbf{F}$ & $\%$ & $\mathbf{F}$ & $\%$ & $\mathbf{F}$ & $\%$ & $\mathbf{F}$ & $\%$ \\
\hline 2-5 participants & 5 & 45.5 & 1 & 100 & & & 7 & 63.6 & 1 & 50 & & & 14 & 37 \\
\hline $\begin{array}{l}6-10 \text { participants } \\
\text { More than } 10 \text { participants }\end{array}$ & 6 & 54.5 & & & 1 & 100 & 4 & 36.4 & 1 & 50 & 12 & 100 & $\begin{array}{r}24 \\
0\end{array}$ & $\begin{array}{r}63.2 \\
0\end{array}$ \\
\hline $\mathrm{N}$ per country/territory & 11 & & 1 & & 1 & & 11 & & 2 & & 12 & & 38 & 100 \\
\hline
\end{tabular}

Note: $\quad \mathrm{N}=38$.

\subsubsection{Individual counselling}

Individual counselling and facilitators

Service providers offering individual counselling $(n=50)$ were asked about the gender of the facilitators, with 35 programmes responding to this question.

As shown in Table 29, of the facilities that provided individual work, more than half reported having both options: one facilitator male $(\mathrm{N}=20 ; 57.1 \%)$ and mixed teams $(\mathrm{N}=20 ; 57.1 \%)$. Moreover, 17 programmes (48.6\%) offer individual counselling with one female facilitator. 
Table 29: Gender of the facilitators

\begin{tabular}{|c|c|c|c|c|c|c|c|c|c|c|c|c|c|c|}
\hline & \multicolumn{2}{|c|}{ Iceland } & \multicolumn{2}{|c|}{ Sweden } & \multicolumn{2}{|c|}{ Denmark } & \multicolumn{2}{|c|}{$\begin{array}{l}\text { Faroe } \\
\text { Islands }\end{array}$} & \multicolumn{2}{|c|}{ Greenland } & \multicolumn{2}{|c|}{ Norway } & \multicolumn{2}{|c|}{ Total } \\
\hline & $\mathbf{F}$ & $\%$ & $\mathbf{F}$ & $\%$ & $\mathbf{F}$ & $\%$ & $\mathbf{F}$ & $\%$ & $\mathbf{F}$ & $\%$ & $\mathbf{F}$ & $\%$ & $F^{*}$ & $\% *$ \\
\hline One Facilitator Male & 1 & 100 & 4 & 23.5 & 3 & 75 & & & 1 & 100 & 11 & 91.7 & 20 & 57.1 \\
\hline One Facilitator Female & 1 & 100 & 3 & 17.6 & 2 & 50 & & & & & 11 & 91.7 & 17 & 48.6 \\
\hline Male team & & & 1 & 5.9 & & & & & & & 11 & 91.7 & 12 & 34.3 \\
\hline Female Team & & & & & & & & & & & 11 & 91.7 & 11 & 31.4 \\
\hline Mixed Team & & & 8 & 47 & & & 1 & 100 & & & 11 & 91.7 & 20 & 57.1 \\
\hline $\begin{array}{l}\mathrm{N} \text { per country/Total offering } \\
\text { individual work }\end{array}$ & 1 & & 17 & & 4 & & 1 & & 1 & & 11 & & & \\
\hline
\end{tabular}

Note: $\mathrm{N}=35$.

* More than one option could be ticked.

\subsubsection{Framework of individual counselling}

Frequency of individual sessions

All of the service providers that answered this question $(n=27)$ had individual sessions on a weekly basis. Moreover, most of them, with the exception of Iceland, reported also fortnightly sessions. Denmark had on service provider that had individual sessions twice a week. Finally, Finland, Denmark and Sweden reported some $(1,4$, and 1 correspondingly) service providers that reported offering individual treatment based on need.

\section{Duration of sessions}

Regarding duration of single sessions, as can be seen in Table 30, most of the programmes $(n=16 ; 47.1 \%)$ have 50 minutes long sessions, followed by 11 programmes (32.4\%) that have individual sessions of 1-hour length.

Table 30: Duration of sessions

\begin{tabular}{|c|c|c|c|c|c|c|c|c|c|c|c|c|c|c|}
\hline \multirow[b]{2}{*}{ Minutes } & \multicolumn{2}{|c|}{ Finland } & \multicolumn{2}{|c|}{ Iceland } & \multicolumn{2}{|c|}{ Sweden } & \multicolumn{2}{|c|}{ Denmark } & \multicolumn{2}{|c|}{$\begin{array}{l}\text { Faroe } \\
\text { Islands }\end{array}$} & \multicolumn{2}{|c|}{ Norway } & \multicolumn{2}{|c|}{ Total } \\
\hline & $\mathrm{F}$ & $\%$ & $\mathbf{F}$ & $\%$ & $\mathbf{F}$ & $\%$ & F & $\%$ & $\mathbf{F}$ & $\%$ & F & $\%$ & $\mathbf{F}$ & $\%$ \\
\hline 45 & & & & & 4 & 27 & & & 1 & 100 & & & 5 & 14.7 \\
\hline 50 & & & 1 & 100 & 2 & 13.3 & 2 & 50 & & & 11 & 100 & 16 & 47.1 \\
\hline 60 & & & & & 8 & 53 & 2 & 50 & & & 1 & 9.1 & 11 & 32.4 \\
\hline 90 & 1 & 100 & & & 1 & 6.7 & & & & & & & 2 & 5.9 \\
\hline $\begin{array}{l}\text { N per countryl } \\
\text { territory }\end{array}$ & 1 & & 1 & & 15 & & 4 & & 1 & & 11 & & & 100 \\
\hline
\end{tabular}

Note: $\mathrm{N}=34$.

Duration of individual work:

In terms of the duration of individual treatment, a duration of " 14 to 26 weeks" and " 27 up to 52 weeks" were reported by the same number of programmes ( $n=7 ; 22.6 \%)$ 
Table 31: Duration of individual counselling

\begin{tabular}{|c|c|c|c|c|c|c|c|c|}
\hline & \multicolumn{2}{|c|}{ Sweden } & \multicolumn{2}{|c|}{ Denmark } & \multicolumn{2}{|c|}{ Norway } & \multicolumn{2}{|c|}{ Total } \\
\hline & $\mathbf{F}$ & $\%$ & $\mathbf{F}$ & $\%$ & $\mathbf{F}$ & $\%$ & $\mathbf{F}$ & $\%$ \\
\hline Up to 13 weeks & 2 & 12.5 & & & & & 2 & 6.5 \\
\hline 14 up to 26 weeks & 5 & 31.3 & 2 & 50 & & & 7 & 22.6 \\
\hline 27 up to 52 weeks & 6 & 37.5 & 1 & 25 & & & 7 & 22.6 \\
\hline Others & 3 & 18.6 & 1 & 25 & 11 & 100 & 15 & 48.4 \\
\hline $\mathrm{N}$ per country/territory & 16 & & 4 & & 11 & & & 100 \\
\hline
\end{tabular}

Note: $\mathrm{N}=31$.

Regarding the "others" section, Sweden (3), Denmark (1) and Norway (11) reported that the duration was as required and was not pre-fixed.

Treatment modality for individual counselling

Service providers were asked if they work according to some established concepts or a specific model in individual counselling.

The majority of programmes $(n=35 ; 71.4 \%)$ answered no to this question.

Table 32: Concept of model in individual counselling

\begin{tabular}{|c|c|c|c|c|c|c|c|c|c|c|c|c|c|c|c|c|}
\hline & \multicolumn{2}{|c|}{ Finland } & \multicolumn{2}{|c|}{ Iceland } & \multicolumn{2}{|c|}{ Sweden } & \multicolumn{2}{|c|}{ Denmark } & \multicolumn{2}{|c|}{$\begin{array}{l}\text { Faroe } \\
\text { Islands }\end{array}$} & \multicolumn{2}{|c|}{ Greenland } & \multicolumn{2}{|c|}{ Norway } & \multicolumn{2}{|c|}{ Total } \\
\hline & $\mathbf{F}$ & $\%$ & F & $\%$ & $\mathbf{F}$ & $\%$ & $\mathbf{F}$ & $\%$ & $\mathbf{F}$ & $\%$ & $\mathbf{F}$ & $\%$ & $\mathbf{F}$ & $\%$ & $\mathbf{F}$ & $\%$ \\
\hline Yes & 3 & 21.4 & & & 10 & 58.8 & 1 & 25 & & & & & & & 14 & 28.6 \\
\hline No & 11 & 78.6 & 1 & 100 & 7 & 41.2 & 3 & 75 & 1 & 100 & 1 & 100 & 11 & 10 & 35 & 71.4 \\
\hline $\begin{array}{l}\text { N per country/ } \\
\text { territory }\end{array}$ & 14 & & 1 & & 17 & & 4 & & 1 & & 1 & & 11 & & 49 & 100 \\
\hline
\end{tabular}

Note: $\quad \mathrm{N}=49$.

Figure 23: Concept of the model on individual counselling

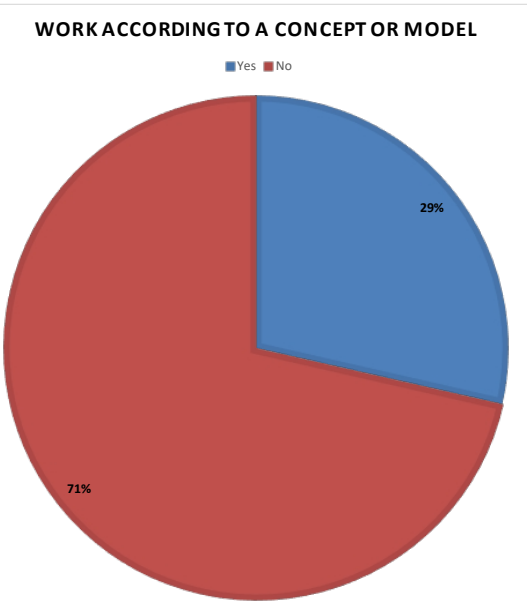


The countries/territories that answered yes were asked to specify the concept they followed:

- Finland had three service providers that reported working according to the psychodynamic model.

- Sweden reported that 10 service providers worked either entirely or partly with the ATV model, in addition to the psychodynamic models and systemic theor.

- The Faroe Islands reported not working according to one model but to following a psychoeducation and psychodynamic model.

- Denmark had 1 service provider offering $C B T$, mindfulness and mentalization.

- Greenland will work according to a manual, but is still under preparation.

- Finally, Norway had 11 ATV-offices that offered a multimodal violence-specific psychotherapy. The therapeutic work included themes associated with violent behaviour such as safety, power, control, and gender issues (Råkil, 2006). Interventions are based on general psychological theories and include elements from cognitive behavioural therapy, emotion-focused therapy, trauma-focused therapy, and psychodynamic-inspired therapy. The treatment takes the view that violent behaviour could be integrated as part of a broader spectre of psychological problems, typically depression and anxiety, trauma-specific reactions, attachment difficulties, and alcohol- or substance abuse. The individual client's psychological problems and strengths guide the therapeutic work. The therapy offered is not time-limited, but adjusted to the needs of each client. Norway also had one SBM service provider that offered CBT treatment.

\subsubsection{Couples counselling}

\section{Couples counselling and facilitators}

Service providers who offered couples counselling $(n=31)$ were asked about the gender of the facilitators of the couples counselling.

As shown in Table 33, couples counselling was most often conducted by a mixed team of facilitators $(n=13 ; 72.2 \%)$, followed by a female team $(n=12 ; 66.7 \%)$ and a male team $(n=11 ; 61.1 \%)$.

Table 33: Gender facilitators

\begin{tabular}{|c|c|c|c|c|c|c|c|c|}
\hline & \multicolumn{2}{|c|}{ Sweden } & \multicolumn{2}{|c|}{ Denmark } & \multicolumn{2}{|c|}{ Norway } & \multicolumn{2}{|c|}{ Total } \\
\hline & $\mathrm{F}$ & $\%$ & $\mathbf{F}$ & $\%$ & F & $\%$ & $F^{*}$ & $\% *$ \\
\hline One Facilitator Male & 1 & 25 & 2 & 67 & & & 2 & 16.7 \\
\hline One Facilitator Female & & & 1 & 33 & & & 1 & 5.6 \\
\hline Male team & & & & & 11 & 100 & 11 & 61.1 \\
\hline Female Team & 1 & 25 & & & 11 & 100 & 12 & 66.7 \\
\hline Mixed Team & 2 & 50 & & & 11 & 100 & 13 & 72.2 \\
\hline $\mathrm{N}$ per country/territory & 4 & & 3 & & 11 & & & \\
\hline
\end{tabular}


Note: $\quad \mathrm{N}=18$

*More than one option could be ticked.

\subsubsection{Framework for couple counselling}

Frequency of couple sessions

Just two countries answered this question. Sweden $(n=2)$ reported one service provider as having couples meetings weekly and another referred to having them on the basis of the couple's needs. All the respondents from Norway $(n=11)$ referred to having couple meetings as was necessary, and on the basis of the couple needs.

\section{Duration of sessions}

Regarding the duration of single sessions, Table 34 shows that couples sessions most typically last for 60 minutes $(n=7 ; 23.3 \%)$ or 90 minutes $(n=10 ; 33.3 \%)$.

Table 34: Duration of sessions

\begin{tabular}{|c|c|c|c|c|c|c|c|c|c|c|}
\hline & \multicolumn{2}{|c|}{ Finland } & \multicolumn{2}{|l|}{ Iceland } & \multicolumn{2}{|c|}{ Sweden } & \multicolumn{2}{|c|}{ Denmark } & \multicolumn{2}{|c|}{ Total } \\
\hline & $F$ & $\%$ & $\mathbf{F}$ & $\%$ & & $\mathbf{F}$ & $\%$ & $F$ & $\%$ & \\
\hline 45 & 2 & 16.7 & & & & & & & 2 & 6.6 \\
\hline 60 & 4 & 33.3 & 1 & 25 & 2 & 66.7 & & & 7 & 23.3 \\
\hline 90 & 6 & 50 & 3 & 75 & 1 & 33.3 & & & 10 & 33.3 \\
\hline Others & & & & & & & 11 & 100 & 11 & 36.7 \\
\hline $\mathrm{N}$ per country/territory & 12 & & 4 & & 3 & & 11 & & & 100 \\
\hline
\end{tabular}

Note: $\quad \mathrm{N}=30$.

Regarding the "others" option, Norway had 11 service providers that reported the length of the sessions varied on the basis of need, and that it was decided on a clinical basis.

Duration of couples work:

In terms of the duration of individual treatment, up to 5 sessions was most typical ( $n=11$; $36.7 \%)$.

Table 35: Duration of couples work

\begin{tabular}{|c|c|c|c|c|c|c|c|c|c|c|}
\hline & \multicolumn{2}{|c|}{ Finland } & \multicolumn{2}{|c|}{ Sweden } & \multicolumn{2}{|c|}{ Denmark } & \multicolumn{2}{|c|}{ Norway } & \multicolumn{2}{|c|}{ Total } \\
\hline & $\mathbf{F}$ & $\%$ & $\mathbf{F}$ & $\%$ & $\mathbf{F}$ & $\%$ & $\mathbf{F}$ & $\%$ & $\mathbf{F}$ & $\%$ \\
\hline Up to 5 sessions & 10 & $83 \cdot 3$ & 1 & 25 & & & & & 11 & 36.7 \\
\hline 6 to 10 sessions & & & 2 & 50 & 2 & 66.7 & & & 4 & 13 \\
\hline More than 10 sessions & & & 1 & 25 & & & & & 1 & 3.3 \\
\hline Others & 2 & 16.7 & & & 1 & $33 \cdot 3$ & 11 & 100 & 24 & 46.7 \\
\hline $\mathrm{N}$ per country/territory & 12 & & 4 & & 3 & & 11 & & 40 & 100 \\
\hline
\end{tabular}

Note: $\quad \mathrm{N}=30$.

Regarding the "others" option: 
- Finland, Denmark, and Norway had service providers who reported that the length is decided on the basis of need, and Finland had one service provider who reported that there is only one meeting.

Treatment modality for couple counselling Regarding the question if they work according to some established concepts or a specific model in couples counselling, Finland reported that they do not work according to any specific model $(75 \% ; n=9)$, Sweden had two service providers (50\%) reporting that they do work according to a model, and finally Denmark reported that one service provider (33.3\%) worked according to a specific model. For Sweden, the model was Sandra Stith and Justine van Lawick, while in Denmark the model was the IMAGO couples' therapy and emotional focused therapy (EFT).

Perpetrator attendees in the programmes

Service providers were asked how many perpetrators attended the program in the last year. Table 36 shows that 5 out of 7 countries have a treatment service attended by more than 50 perpetrators, indeed the most common answer was to have more than 50 perpetrators $(n=24 ; 51 \%)$ attending.

Table 36: Perpetrators that attended the programme

\begin{tabular}{|c|c|c|c|c|c|c|c|c|c|c|c|c|c|c|c|c|}
\hline & \multicolumn{2}{|c|}{ Finland } & \multicolumn{2}{|c|}{ Åland } & \multicolumn{2}{|c|}{ Iceland } & \multicolumn{2}{|c|}{ Sweden } & \multicolumn{2}{|c|}{ Denmark } & \multicolumn{2}{|c|}{$\begin{array}{l}\text { Faroe } \\
\text { Islands }\end{array}$} & \multicolumn{2}{|c|}{ Norway } & \multicolumn{2}{|c|}{ Total } \\
\hline & $\mathbf{F}$ & $\%$ & $\mathbf{F}$ & $\%$ & $F$ & $\%$ & $F$ & $\%$ & $F$ & $\%$ & $\mathbf{F}$ & $\%$ & $F$ & $\%$ & $F$ & $\%$ \\
\hline $\begin{array}{l}\text { Less than } 25 \\
\text { perpetrators }\end{array}$ & 1 & 7.1 & 1 & 100 & & & 3 & 21.4 & 2 & 50 & 1 & 100 & & & 8 & 17 \\
\hline $\begin{array}{l}25 \text { to } 50 \\
\text { perpetrators }\end{array}$ & 8 & 57.1 & & & & & 6 & 42.9 & 1 & 25 & & & & & 15 & 32 \\
\hline More (approx.) & 5 & 35.7 & & & 1 & 100 & 5 & 35.7 & 1 & 25 & & & 12 & 100 & 24 & 51 \\
\hline $\begin{array}{l}\text { N per country/ } \\
\text { territory }\end{array}$ & 14 & & 1 & & 1 & & 14 & & 4 & & 1 & & 12 & & & 100 \\
\hline
\end{tabular}

Note: $\quad \mathrm{N}=50$. 
Figure 24: Perpetrators that attended the programme

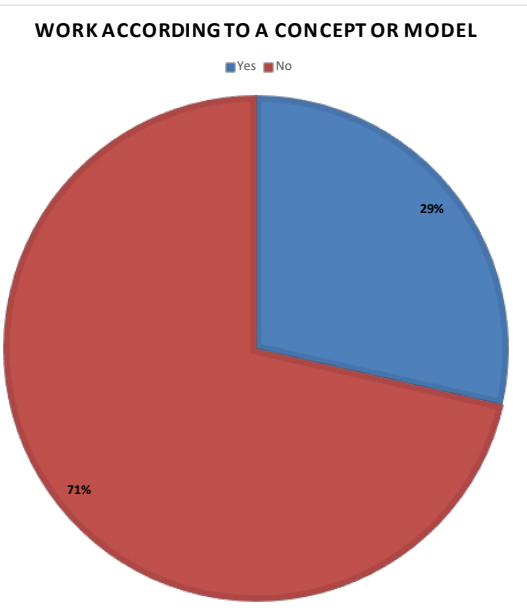

Figure 25: Perpetrators that attended the programme

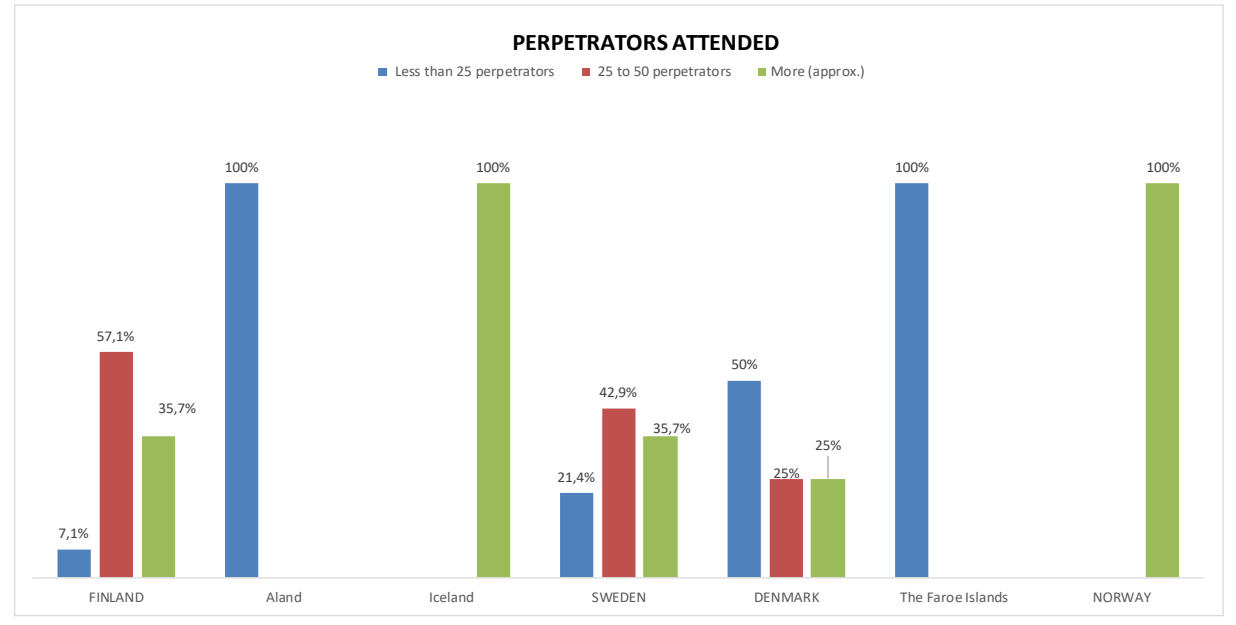

Programmes that reported "more than 50 perpetrators" attending were asked to give a specific number. In the Finnish cities, the most common Figure was up to 200 perpetrators (per programme), with up to 1,200 perpetrators in total. In Iceland, 86 perpetrators were in attendance and in Denmark one service provider reported 482 perpetrators attending. In Norway the ATV service providers had a total of 920 perpetrators attending (for the 11 programmes together; around 80 per programme), while the SBM service provider had go perpetrators attending.

Perpetrators that completed the programme in the last year

The programmes were asked to report the number of perpetrators that completed the program in the last year. Most of them $(n=25 ; 53.2 \%)$ reported that between $50 \%$ and $75 \%$ of the perpetrators completed the programme. In Finland, Sweden, Denmark and the Faroe Islands, some programmes had more than $75 \%$ of perpetrators completing the programme. 
Table 37: Perpetrators that completed the programme

\begin{tabular}{|c|c|c|c|c|c|c|c|c|c|c|c|c|c|c|}
\hline & \multicolumn{2}{|c|}{ Finland } & \multicolumn{2}{|c|}{ Iceland } & \multicolumn{2}{|c|}{ Sweden } & \multicolumn{2}{|c|}{ Denmark } & \multicolumn{2}{|c|}{$\begin{array}{l}\text { Faroe } \\
\text { Islands }\end{array}$} & \multicolumn{2}{|c|}{ Norway } & \multicolumn{2}{|c|}{ Total } \\
\hline & $F$ & $\%$ & $F$ & $\%$ & $\mathbf{F}$ & $\%$ & $F$ & $\%$ & $F$ & $\%$ & $F$ & $\%$ & $\mathbf{F}$ & $\%$ \\
\hline $\begin{array}{l}\text { Less than } 50 \text { of } \\
\text { attended } \\
\text { perpetrators }\end{array}$ & 1 & 7 & 1 & 100 & 3 & 18.8 & 1 & 25 & & & & & 6 & 12.8 \\
\hline $\begin{array}{l}50 \text { to } 75 \text { of } \\
\text { perpetrators }\end{array}$ & 6 & 42.9 & & & 7 & 43.8 & 1 & 25 & & & 11 & 91.7 & 25 & 53.2 \\
\hline $\begin{array}{l}\text { Over } 75 \text { of } \\
\text { perpetrators }\end{array}$ & 5 & 35.7 & & & 6 & 37.5 & 2 & 50 & 1 & 100 & & & 14 & 29.8 \\
\hline $\begin{array}{l}\text { (Exact percentage if } \\
\text { you know) }\end{array}$ & 1 & 7.1 & & & & & & & & & 1 & 8.3 & 2 & $4 \cdot 3$ \\
\hline $\begin{array}{l}\text { N per country } \\
\text { /territory }\end{array}$ & 13 & & 1 & & 16 & & 4 & & 1 & & 12 & & & 98 \\
\hline
\end{tabular}

Note: $\quad N=47$.

Figure 26: Perpetrators that completed the programme

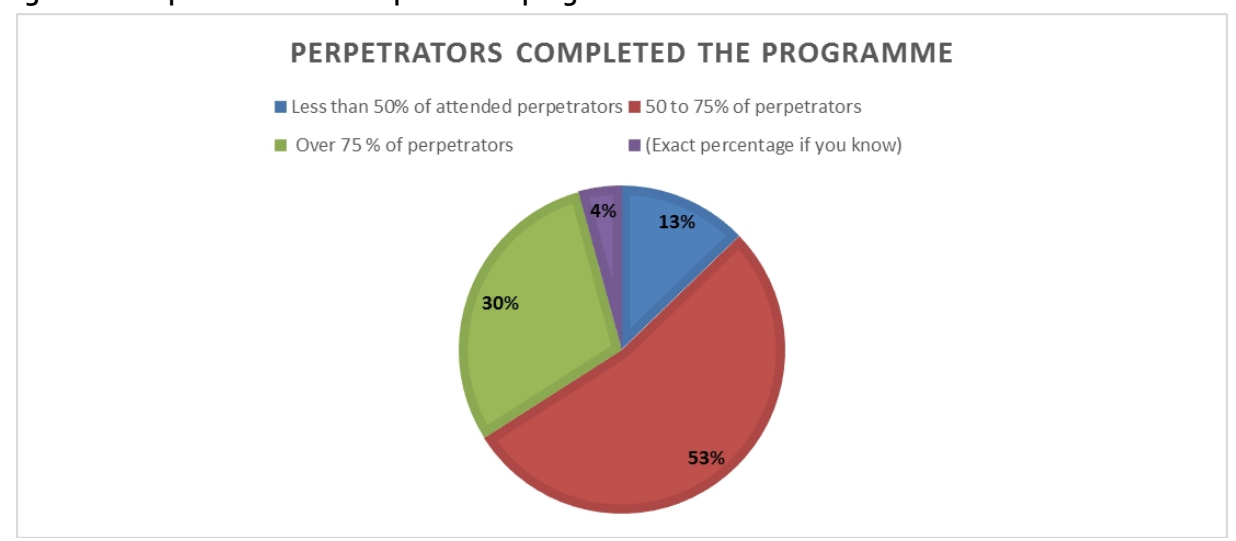

Figure 27: Perpetrators that completed the programme

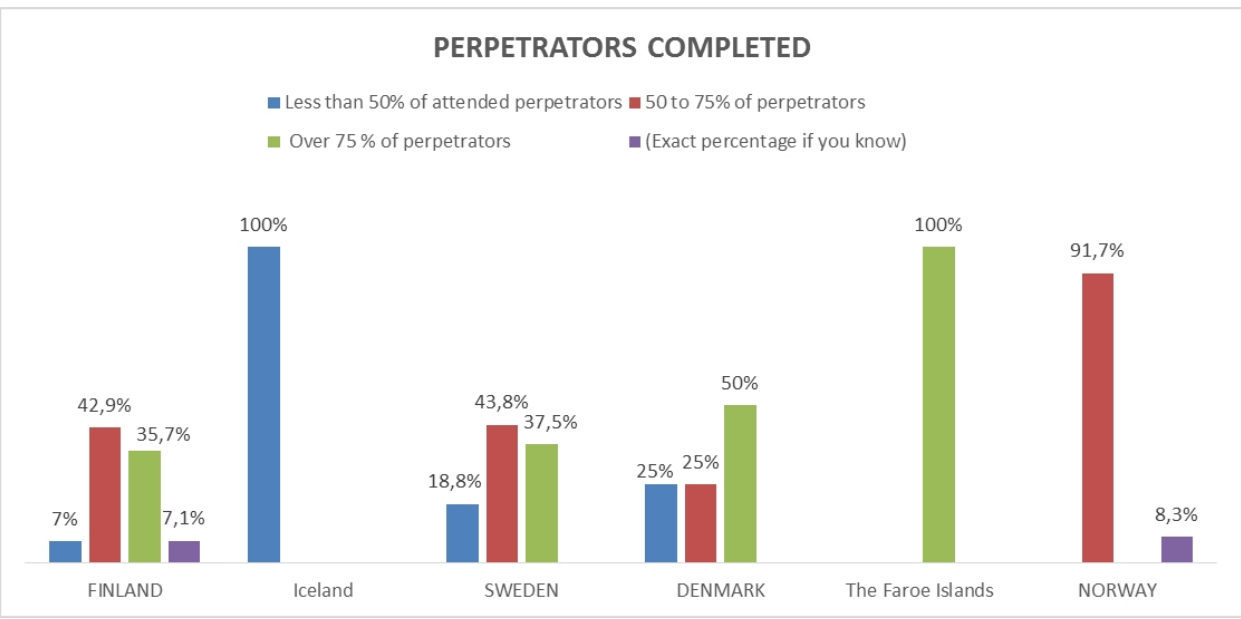


The exact percentage was requested if the service providers had this information. One service provider in Finland reported that $20 \%$ of the perpetrators finished the programme, one service provider in Denmark reported that 191 of 482 perpetrators finished it (39.6\%), and the SBM service provider in Norway reported that $65 \%$ finished it (for ATV it was from $50-75 \%$ ).

\subsection{Section E: content of work}

\subsubsection{Main goals of the programme}

This open question asked the programme organisers to reflect on the three main goals of their programme.

Mentioned as the main goals were ending violent behaviour, taking responsibility for it, and ensuring safety. One service provider reported raising awareness of the special characteristics of violence by women as their main goal. As the second main goals it was mentioned ending violence and taking responsibility, working on emotional self-regulation and communication skills, safety, and reducing harmful effects for victims of violence, and perpetrators understanding their violent acts and the psychological causes. Finally, the third main goals included increasing insight into own behaviour and consequences of violence, improving mentalizing ability in parenting skills, ensuring the well-being of children and the family, stopping the transmission of violence, increasing the quality of life and self-respect of the perpetrator.

\subsubsection{Written curriculum or manual}

Only $28 \%(n=11)$ of the facilities used a written curriculum or manual.

Table 38: Use of a written curriculum or manual

\begin{tabular}{|c|c|c|c|c|c|c|c|c|c|c|c|c|c|c|c|c|}
\hline & \multicolumn{2}{|c|}{ Finland } & \multicolumn{2}{|c|}{ Iceland } & \multicolumn{2}{|c|}{ Sweden } & \multicolumn{2}{|c|}{ Denmark } & \multicolumn{2}{|c|}{$\begin{array}{l}\text { Faroe } \\
\text { Islands }\end{array}$} & \multicolumn{2}{|c|}{ Greenland } & \multicolumn{2}{|c|}{ Norway } & \multicolumn{2}{|c|}{ Total } \\
\hline & $F$ & $\%$ & $F$ & $\%$ & $\mathbf{F}$ & $\%$ & $\mathbf{F}$ & $\%$ & F & $\%$ & $\mathbf{F}$ & $\%$ & $\mathbf{F}$ & $\%$ & F & $\%$ \\
\hline Yes & 4 & 33.3 & 1 & 100 & 4 & 23.5 & 3 & 75 & & & 1 & 100 & 1 & 8.3 & 11 & 28 \\
\hline No & 10 & 71.4 & & & 13 & 76.5 & 1 & 25 & 1 & 100 & & & 11 & 91.7 & 23 & 72 \\
\hline $\begin{array}{l}\text { N per countryl } \\
\text { territory }\end{array}$ & 14 & & 1 & & 17 & & 4 & & 1 & & 1 & & 12 & & 34 & 100 \\
\hline
\end{tabular}

Note: $\quad \mathrm{N}=50$. 
Figure 28: Use of a written curriculum or manual

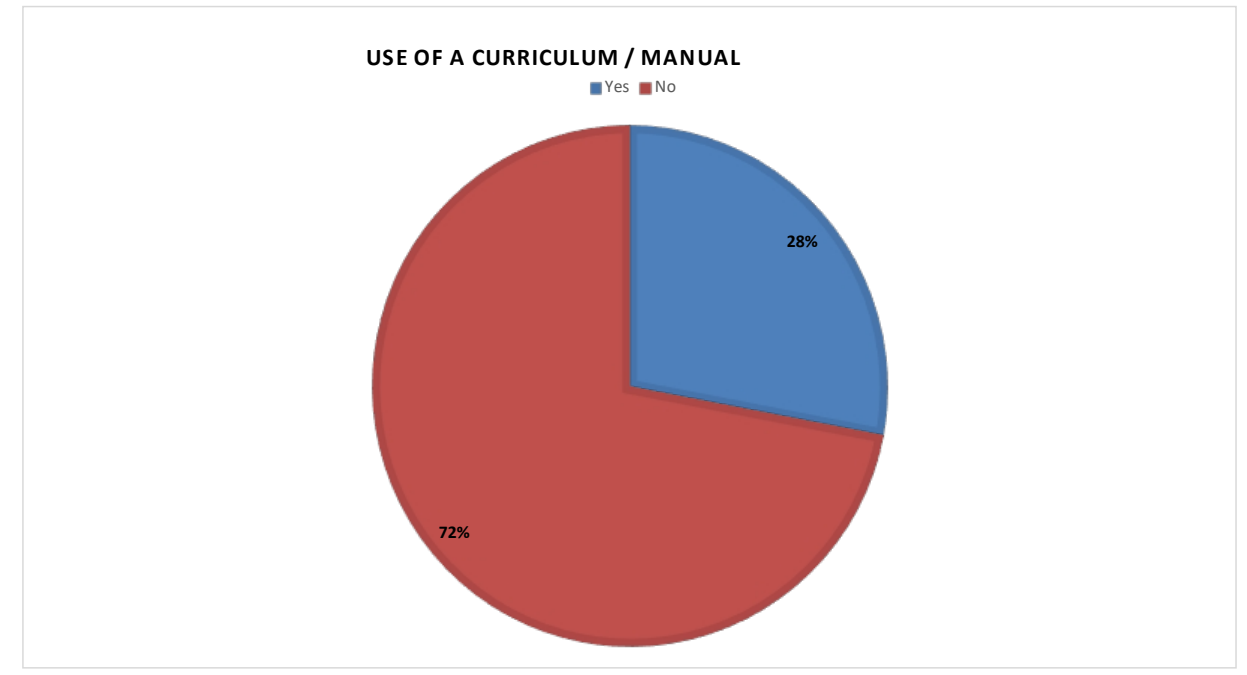

Figure 29: Use of a written curriculum or manual

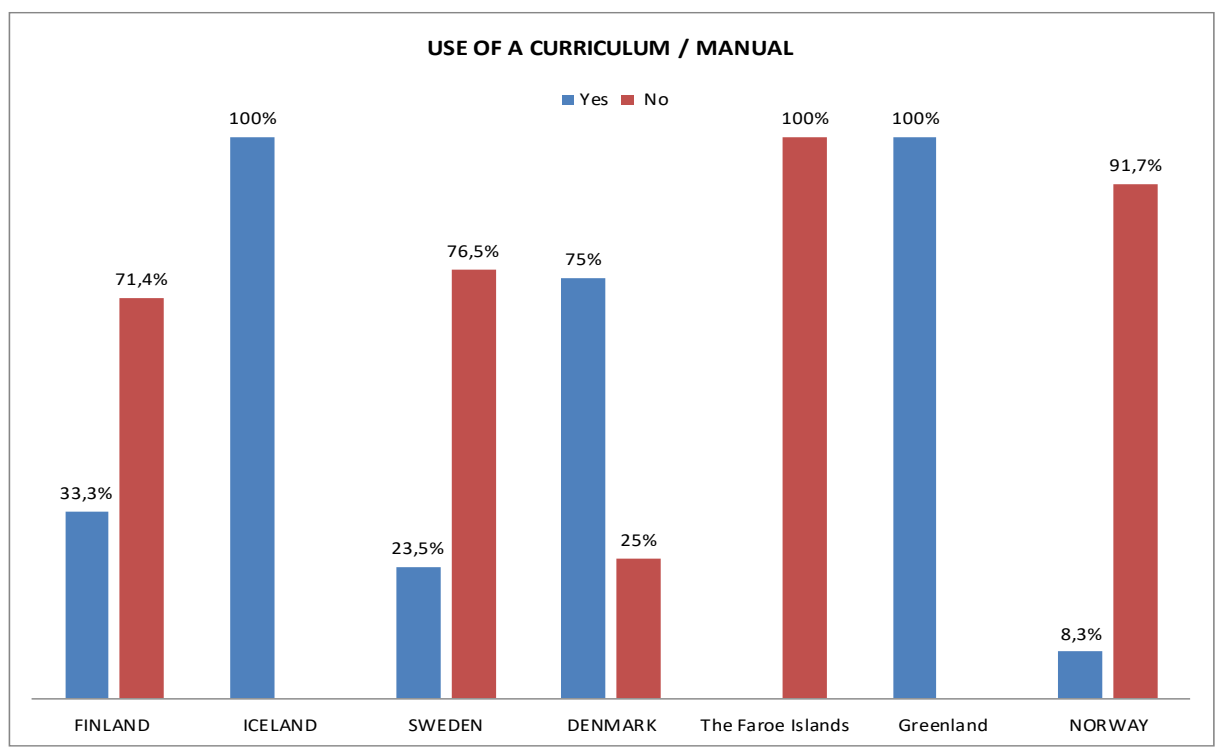

The programmes were asked to specify what manual they followed: Norway reported that while the ATV does not follow a written curriculum, during the assessment it uses several clinical and safety tools. Moreover, it reported that some treatment groups make use of a manual by Per Isdal. Other groups are not structured according to a specific manual but are more process-based, with a focus on violent behaviour and are centred within the general ATV-methodology.

\subsubsection{Core elements of the work}


As shown in Table 39 the main elements of the work were to work on the accountability / responsibility for the violent behaviour of the perpetrators ( $n=48 ; 98 \%)$, to work on the effects of domestic violence on the victim and increase the perpetrators" empathy for the victim ( $n=47 ; 96 \%)$ and working on fathering and the effects of domestic violence on children ( $n=47 ; 96 \%)$. Most of the elements proposed seem to be important for the facilities, since even the least less-mentioned dimension "alcohol / drugs and violence" was indicated 23 times (47\%).

\section{Table 39: Core elements of work}

\begin{tabular}{|c|c|c|c|c|c|c|c|c|c|c|c|c|c|c|}
\hline & \multicolumn{2}{|c|}{ Finland } & \multicolumn{2}{|c|}{ Iceland } & \multicolumn{2}{|c|}{ Sweden } & \multicolumn{2}{|c|}{ Denmark } & \multicolumn{2}{|c|}{$\begin{array}{l}\text { Faroe } \\
\text { Islands }\end{array}$} & \multicolumn{2}{|c|}{ Norway } & \multicolumn{2}{|c|}{ Total } \\
\hline & $\mathbf{F}$ & $\%$ & $\mathbf{F}$ & $\%$ & $\mathbf{F}$ & $\%$ & $\mathbf{F}$ & $\%$ & $\mathbf{F}$ & $\%$ & $\mathbf{F}$ & $\%$ & $F^{*}$ & $\% *$ \\
\hline $\begin{array}{l}\text { Gender roles and stereotypes } \\
\text { (masculinity and femininity) }\end{array}$ & 7 & 50 & & & 13 & 76.5 & 2 & 50 & & & 11 & 91.7 & 33 & $67 \cdot 3$ \\
\hline Gender-specific power and control & 7 & 50 & & & 15 & 88.2 & 3 & 75 & & & 11 & 91.7 & 36 & 73.5 \\
\hline $\begin{array}{l}\text { Attitudes and beliefs that support } \\
\text { violence }\end{array}$ & 13 & 92.9 & 1 & 100 & 15 & 88.2 & 4 & 100 & & & 12 & 100 & 45 & 91.9 \\
\hline $\begin{array}{l}\text { Accountability / responsibility for the } \\
\text { violent behaviour }\end{array}$ & 14 & 100 & 1 & 100 & 16 & 94.1 & 4 & 100 & 1 & 100 & 12 & 100 & 48 & 98 \\
\hline $\begin{array}{l}\text { Effects of domestic violence on the } \\
\text { victim / empathy for the victim }\end{array}$ & 14 & 100 & 1 & 100 & 15 & 88.2 & 4 & 100 & 1 & 100 & 12 & 100 & 47 & 95.9 \\
\hline $\begin{array}{l}\text { Fathering and effects of domestic } \\
\text { violence on children }\end{array}$ & 14 & 100 & 1 & 100 & 16 & 94.1 & 4 & 100 & & & 12 & 100 & 47 & $95 \cdot 9$ \\
\hline Alcohol / drugs and violence & & & 1 & 100 & 8 & 47.1 & 2 & 100 & & & 12 & 100 & 23 & 46.9 \\
\hline $\begin{array}{l}\text { Recognizing High-risk situations (e. g. } \\
\text { separation) }\end{array}$ & 11 & 78.6 & 1 & 100 & 13 & 76.5 & 4 & 100 & & & 12 & 100 & 41 & 83.7 \\
\hline $\begin{array}{l}\text { Definition of violence / types of abuse } \\
\text { (e. g. wheel of violence) }\end{array}$ & 12 & 85.7 & 1 & 100 & 17 & 100 & 3 & 75 & & & 12 & 100 & 45 & 91.8 \\
\hline Reconstruction of violent act(s) & 11 & 78.6 & & & 15 & 88.2 & 2 & 50 & & & 12 & 100 & 40 & 81.6 \\
\hline $\begin{array}{l}\text { Confrontation with justification and } \\
\text { minimizing strategies }\end{array}$ & 10 & 71.4 & 1 & 100 & 14 & 82.4 & 3 & 75 & & & 12 & 100 & 40 & 81.6 \\
\hline Time out & 13 & 92.9 & 1 & 100 & 15 & 88.2 & 3 & 75 & & & 12 & 100 & 44 & 89.8 \\
\hline Anger management & 11 & 78.6 & 1 & 100 & 13 & 76.5 & 3 & 75 & 1 & 100 & 12 & 100 & 41 & 83.7 \\
\hline $\begin{array}{l}\text { Personal history of violence } \\
\text { (biographical work) }\end{array}$ & 13 & 92.9 & 1 & 100 & 17 & 100 & 3 & 75 & & & 12 & 100 & 46 & 93.9 \\
\hline Egalitarian relationship & 11 & 78.6 & & & 10 & 58.8 & 3 & 75 & & & & 100 & 24 & 49 \\
\hline $\begin{array}{l}\text { Social skills (communication / conflict } \\
\text { resolution) }\end{array}$ & 11 & 78.6 & 1 & 100 & 13 & 76.5 & 4 & 100 & 1 & 100 & & 100 & 30 & 61.2 \\
\hline $\begin{array}{l}\text { Self-awareness, self-reflection and } \\
\text { emotional expression }\end{array}$ & 14 & 100 & 1 & 100 & 17 & 100 & 4 & 100 & 1 & 100 & & 100 & 37 & $75 \cdot 5$ \\
\hline $\begin{array}{l}\text { Social relationships (friendship, social } \\
\text { networks) }\end{array}$ & 8 & 57.1 & 1 & 100 & 14 & 82.4 & 3 & 75 & 1 & 100 & & 100 & 27 & 55.1 \\
\hline $\mathrm{N}$ per country/territory & 14 & & 1 & & 17 & & 4 & & 1 & & 12 & & & \\
\hline
\end{tabular}


Note: $\mathrm{N}=49$.

* More than one option could be ticked.

Figure 30 : Core elements of work

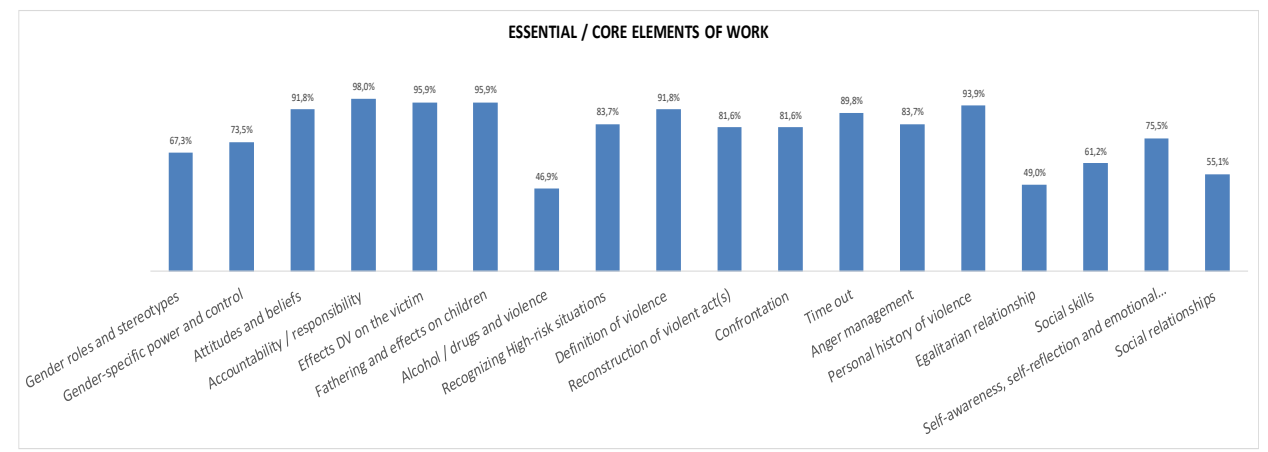

Regarding "Others" option:

- Finland emphasized as important the following elements of work: Creating a safety plan, increasing reflecting abilities and self-knowledge about personally relevant socioemotional tendencies.

- Sweden reported sexuality and trauma-related work as core elements in their work.

- Denmark reported self-esteem, resource focus, and an appreciative approach as important elements of the work.

- Finally, the Faroe Islands reported work on emotional expression as being important.

\subsection{Section F: partner contact}

\subsubsection{Contact with the partner}

When asked if they contact the partner / ex-partner of the clients, just 8 facilities (19\%) reported that they do not contact the partner. In Finland and Denmark around one third of programmes did not contact the partner, while in Sweden, just one service did not make contact. In the Faroe Islands the sole service provider did not contact the partner either. On the other hand, in Norway, Iceland, Åland, and Greenland, all the service providers reported contacted the partner. 
Table 40: Partner contact

\begin{tabular}{|c|c|c|c|c|c|c|c|c|c|c|c|c|c|c|c|c|c|c|}
\hline & \multicolumn{2}{|c|}{ Finland } & \multicolumn{2}{|c|}{ Åland } & \multicolumn{2}{|c|}{ Iceland } & \multicolumn{2}{|c|}{ Sweden } & \multicolumn{2}{|c|}{ Denmark } & \multicolumn{2}{|c|}{$\begin{array}{l}\text { Faroe } \\
\text { Islands }\end{array}$} & \multicolumn{2}{|c|}{$\begin{array}{c}\text { Greenlan } \\
\text { d }\end{array}$} & \multicolumn{2}{|c|}{ Norway } & \multicolumn{2}{|c|}{ Total } \\
\hline & $F$ & $\%$ & $\mathbf{F}$ & $\%$ & $F$ & $\%$ & $F$ & $\%$ & $F$ & $\%$ & $F$ & $\%$ & $\mathbf{F}$ & $\%$ & $F$ & $\%$ & F & $\%$ \\
\hline No & 5 & 38.5 & & & & & 1 & 9.1 & 1 & 33.3 & 1 & 100 & & & & & 8 & 19 \\
\hline Yes & 8 & 61.5 & 1 & 100 & 1 & 100 & 10 & 90.9 & 2 & 67 & & & 1 & 100 & 12 & 100 & 35 & 81 \\
\hline $\begin{array}{l}\text { N per country/ } \\
\text { territory }\end{array}$ & 13 & & 1 & & 1 & & 11 & & 3 & & 1 & & 1 & & 12 & & & 100 \\
\hline
\end{tabular}

Note: $\mathrm{N}=43$.

Figure 31: Partner contact

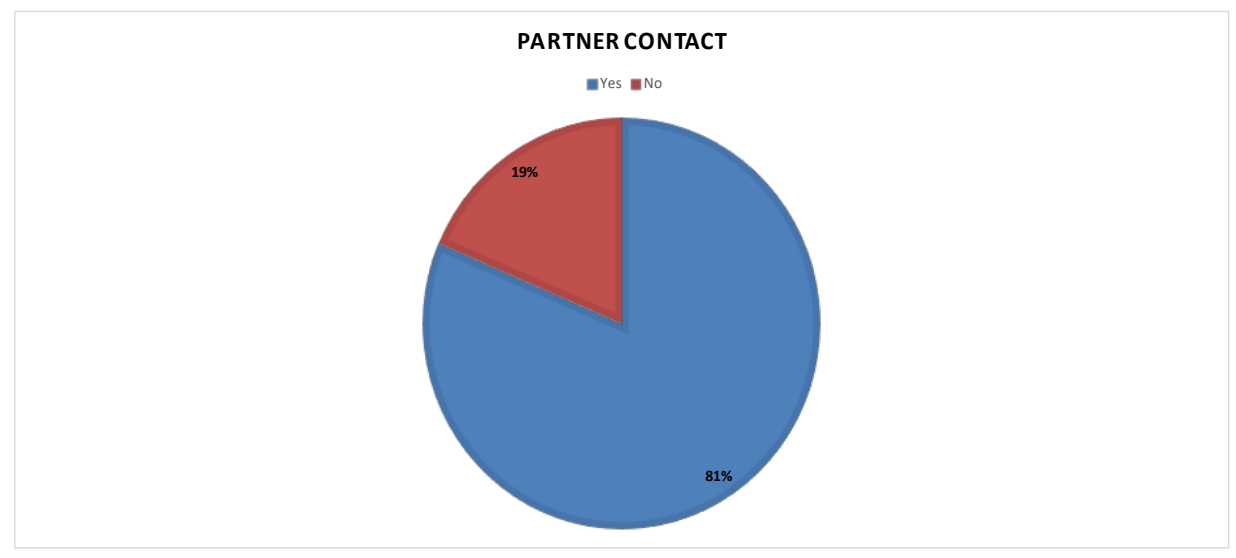

Figure 32: Partner contact

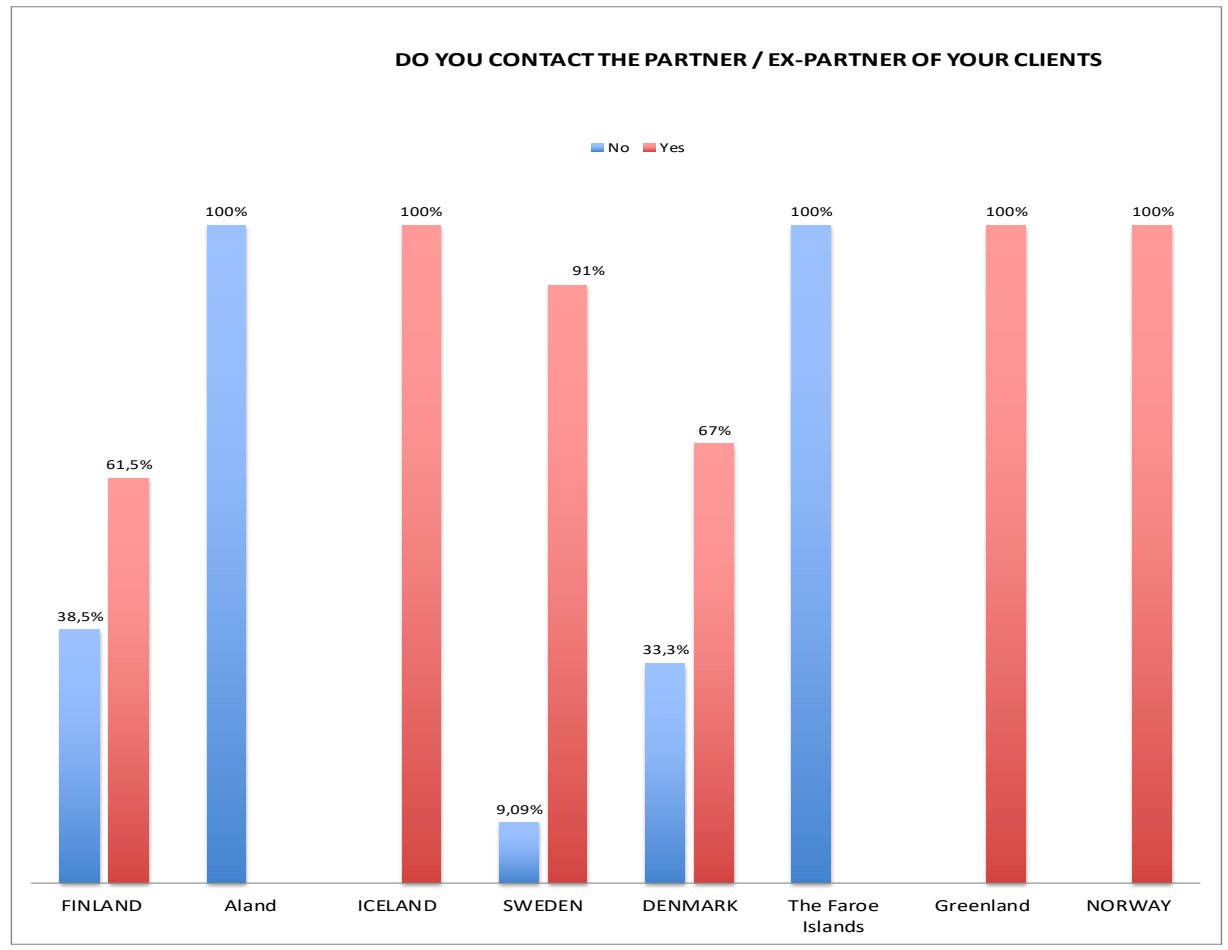


Programmes that contacted the partner $(n=36)$ were asked to specify what partner do they contact. Table 41 shows that programmes mostly contact the current partner (who has suffered violence) ( $n=33 ; 94 \%)$; furthermore, other programmes reported that they also contact the ex-partner (who has suffered violence) $(n=22 ; 64.7 \%)$. The new partner (as a potential victim) was contacted only in Denmark $(n=2 ; 100 \%)$, Sweden $(n=3$; $27.2 \%)$, and Finland $(n=1 ; 12.5 \%)$.

Table 41: Partner that is contacted

\begin{tabular}{|c|c|c|c|c|c|c|c|c|c|c|c|c|}
\hline & \multicolumn{2}{|c|}{ Finland } & \multicolumn{2}{|c|}{ Iceland } & \multicolumn{2}{|c|}{ Sweden } & \multicolumn{2}{|c|}{ Denmark } & \multicolumn{2}{|c|}{ Norway } & \multicolumn{2}{|c|}{ Total } \\
\hline & $\mathbf{F}$ & $\%$ & $\mathbf{F}$ & $\%$ & $\mathbf{F}$ & $\%$ & $\mathbf{F}$ & $\%$ & F & $\%$ & $F^{*}$ & $\% *$ \\
\hline $\begin{array}{l}\text { Current partner (who has } \\
\text { suffered violence) }\end{array}$ & 7 & 87.5 & 1 & 100 & 10 & 90.9 & 2 & 100 & 12 & 100 & 33 & 94.1 \\
\hline $\begin{array}{l}\text { Ex-partner (who has suffered } \\
\text { violence) }\end{array}$ & 2 & 25 & 1 & 100 & 7 & 63.6 & & & 12 & 100 & 22 & 64.7 \\
\hline $\begin{array}{l}\text { New partner (as a potential } \\
\text { victim) }\end{array}$ & 1 & 12.5 & & & 3 & $27 \cdot 3$ & 2 & 100 & & & 6 & 17.6 \\
\hline N per country & 8 & & 1 & & 11 & & 1 & & 12 & & & \\
\hline
\end{tabular}

Note: $\quad \mathrm{N}=34$ ( $(\AA$ land and Greenland did not answer to this question). * More than one option could be ticked.

\subsubsection{Points at which the partner is contacted}

Programmes that contacted the partner $(n=36)$ were asked to specify the points in time at which the partner is contacted. As shown in Table 42, 80\% $(n=29)$ of the programmes reported contacting the (ex-) partner when the client begins the programme. Several facilities reported also contacting the partner at the end of the programme $(n=20$; $57.1 \%)$ or during the course of it $(n=19 ; 54.3 \%)$.

Table 42: Points at which the partner is contacted

\begin{tabular}{|c|c|c|c|c|c|c|c|c|c|c|c|c|c|c|}
\hline & \multicolumn{2}{|c|}{ Finland } & \multicolumn{2}{|c|}{ Åland } & \multicolumn{2}{|c|}{ Iceland } & \multicolumn{2}{|c|}{ Sweden } & \multicolumn{2}{|c|}{ Denmark } & \multicolumn{2}{|c|}{ Norway } & \multicolumn{2}{|c|}{ Total } \\
\hline & $\mathbf{F}$ & $\%$ & $\mathbf{F}$ & $\%$ & $\mathbf{F}$ & $\%$ & F & $\%$ & $\mathbf{F}$ & $\%$ & $\mathbf{F}$ & $\%$ & $\mathrm{~F} *^{*}$ & $\% *$ \\
\hline When client begins the programme & 2 & 25 & 1 & 100 & 1 & 100 & 10 & 90.9 & 2 & 100 & 12 & 100 & 29 & 80 \\
\hline In the course of work & 2 & 25 & & & & & 4 & 36.4 & 1 & 50 & 12 & 100 & 19 & $54 \cdot 3$ \\
\hline At the end of programme & 1 & 12.5 & 1 & 100 & 1 & 100 & 5 & 45.5 & 2 & 100 & 11 & 91.7 & 21 & 60 \\
\hline N per country & 8 & & 1 & & 1 & & 11 & & 2 & & 12 & & 68 & \\
\hline
\end{tabular}

Note: $\quad \mathrm{N}=35$.

*More than one option could be ticked

Other moments that were also specified by the facilities were:

- Finland: one service provider contacts the partner at the beginning, middle, end, and 2 years after the programme; another reported that it only contacts partners seen as being at high-risk; another programme reported that the partner is 
contacted at any stage; finally, another programme reported that contact is made if the client wishes it.

- Sweden: one programme contacted the partner/ex-partner when the partner/expartner asked for contact and when they offered transitional accommodation.

- Denmark: one service reported that they contact the partner/ex-partner one year after the program has ended.

- Programmes that contacted the partner $(n=36)$ were asked to specify the purpose of contacting the partner.

\subsubsection{Purpose of partner contact}

As seen in Table 43, 85.3\% ( $n=29)$ of the programmes contact the partner/ex-partner to share information about specific victim services (e.g. victim's support services, shelters, services for refugees or migrants, counselling services for victims etc.). Moreover, $76.5 \% \quad(n=26)$ of the programmes contacted the partner/ex-partner to share information about the programme and its content. The third most common reason for contacting the partner/ex-partner was that it was important to know about the partner's experience of violence (their view on violent acts) $(n=25 ; 73.5 \%)$

Table 43: Purpose of partner contact

\begin{tabular}{|c|c|c|c|c|c|c|c|c|c|c|c|c|}
\hline & \multicolumn{2}{|c|}{ Finland } & \multicolumn{2}{|c|}{ Iceland } & \multicolumn{2}{|c|}{ Sweden } & \multicolumn{2}{|c|}{ Denmark } & \multicolumn{2}{|c|}{ Norway } & \multicolumn{2}{|c|}{ Total } \\
\hline & $\mathbf{F}$ & $\%$ & $\mathbf{F}$ & $\%$ & $\mathbf{F}$ & $\%$ & $\mathbf{F}$ & $\%$ & $\mathbf{F}$ & $\%$ & $F^{*}$ & $\%$ * \\
\hline $\begin{array}{l}\text { Information about the programme and its } \\
\text { content }\end{array}$ & 5 & $\begin{array}{r}62 . \\
5\end{array}$ & 1 & 100 & 7 & 63.5 & 1 & 50 & 12 & 100 & 26 & 76.5 \\
\hline $\begin{array}{l}\text { Information about specific work methods } \\
\text { (e.g. Time out) }\end{array}$ & & & & & 2 & 18.2 & & & 12 & 100 & 14 & 41.2 \\
\hline $\begin{array}{l}\text { Information about limitation of the } \\
\text { programme (no guarantee for non-violence) }\end{array}$ & & & 1 & 100 & 6 & 54.5 & & & 12 & 100 & 19 & $55 \cdot 9$ \\
\hline $\begin{array}{l}\text { Information about legal options like barring } \\
\text { or protection orders (if existing) }\end{array}$ & & & & & 1 & 9.1 & & & 12 & 100 & 13 & 38.2 \\
\hline $\begin{array}{l}\text { Information about the importance of safety } \\
\text { measures }\end{array}$ & 2 & 25 & 1 & 100 & 9 & 81.8 & & & 12 & 100 & 24 & 70.6 \\
\hline $\begin{array}{l}\text { Information about specific victim services } \\
\text { (e.g. victim's support services, shelters, } \\
\text { services for refugees or migrants, counselling } \\
\text { services for victims etc.) }\end{array}$ & 6 & 75 & 1 & 100 & 10 & 90.9 & & & 12 & 100 & 29 & $85 \cdot 3$ \\
\hline $\begin{array}{l}\text { Partner experience of violence (their view on } \\
\text { violent acts) }\end{array}$ & 6 & 75 & & & 6 & 54.6 & 1 & 50 & 12 & 100 & 25 & $73 \cdot 5$ \\
\hline Evaluation of the programme & 2 & 25 & 1 & 100 & 5 & $45 \cdot 5$ & 2 & 100 & 12 & 91.7 & 22 & 64.7 \\
\hline $\mathrm{N}$ per country/territory & 8 & & 1 & & 11 & & 2 & & 12 & & & \\
\hline
\end{tabular}




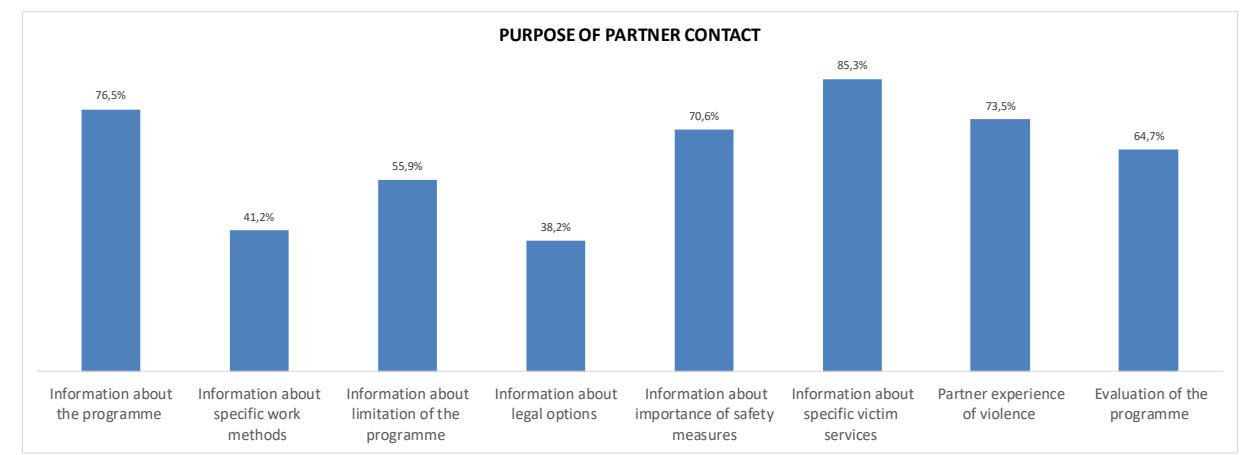

As for other purposes to contact the (ex-) partner:

- Finland: one programme reported that it was important for sharing common knowledge, and another reported that it was important for enabling participation in the programme by the partner.

Not all the service providers answered the question of whether the partner / ex-partner was informed in crisis situations and warned about risks. Programmes in Iceland (100\%; $\mathrm{n}=1)$, Norway $(100 \% ; \mathrm{n}=12)$, and Denmark $(100 \% ; \mathrm{n}=2)$ reported informing about this, while in Sweden $(91 \% ; n=10)$ and Finland $(62.5 \%, n=5)$ the percentage of programmes informing the partners in crisis situations was more than half.

\subsubsection{Victim support and safety}

Support for partner included in the programmes

In total $10.6 \%(n=5)$ of the programmes did not offer any support to the partner, either directly offered by their organization or through a partner organisation. In contrast, a majority of the programmes offered support to the partner that was organised by their organization $(n=36 ; 76.6 \%)$ or through a partner organization $(n=6 ; 12.8 \%)$. In Finland, all the programmes reported offering support services for the partner (provided by either their organizations or by a partner organization), while in Norway and Denmark all the programmes offered support through their organization. 
Table 44: Support for partner included in the programme

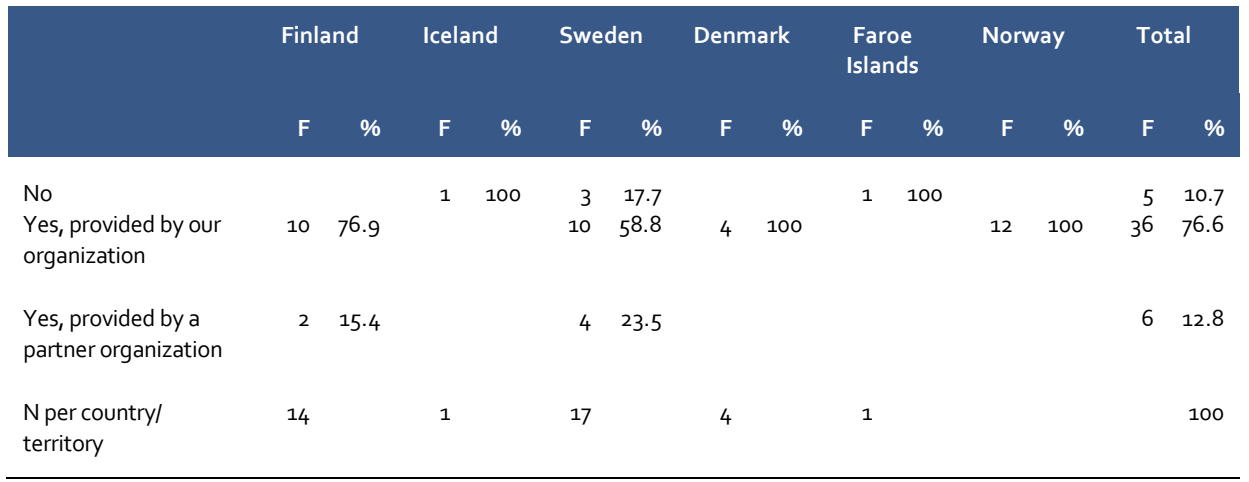

Note: $\quad N=47$.

Figure 34: Support for partner included in the programme

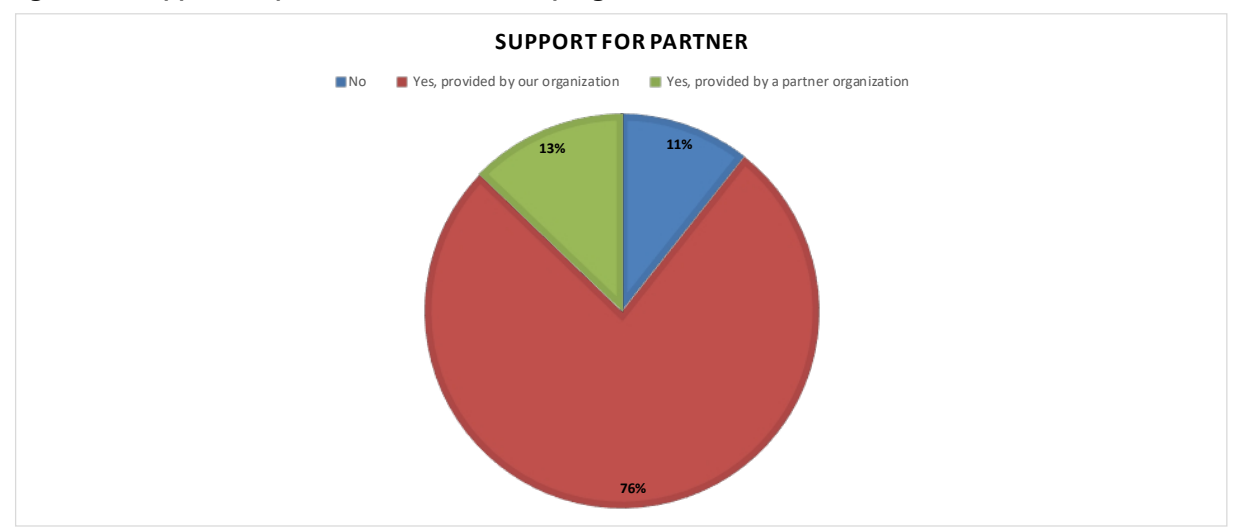

\subsubsection{Type of support service}

Programmes providing support for the victim either from their own organisation or from a partner organisation $(n=42)$ were asked to specify what kind of support is provided. As shown in Table 45, the vast majority of the programmes offer individual support to the partner $(n=40 ; 95.2 \%)$, risk assessment and safety planning $(n=34 ; 81 \%)$, as well as group work $(n=30 ; 71.4 \%)$. 


\begin{tabular}{|c|c|c|c|c|c|c|c|c|c|c|}
\hline & \multicolumn{2}{|c|}{ Finland } & \multicolumn{2}{|c|}{ Sweden } & \multicolumn{2}{|c|}{ Denmark } & \multicolumn{2}{|c|}{ Norway } & \multicolumn{2}{|c|}{ Total } \\
\hline & $\mathbf{F}$ & $\%$ & $\mathbf{F}$ & $\%$ & $\mathbf{F}$ & $\%$ & $\mathbf{F}$ & $\%$ & $F *$ & $\% *$ \\
\hline Individual support & 12 & 100 & 13 & 92.9 & 4 & 100 & 11 & 91.7 & 40 & 95.2 \\
\hline Group work & 11 & 91.7 & 6 & 42.9 & 2 & 50 & 11 & 91.7 & 30 & 71.4 \\
\hline $\begin{array}{l}\text { Regular support during the programme } \\
\text { participation of client }\end{array}$ & 5 & 41.7 & 4 & 28.6 & 2 & 50 & & & 11 & 26.2 \\
\hline $\begin{array}{l}\text { Proactive contacts (contacts initiated by } \\
\text { the support service) }\end{array}$ & 7 & 58.3 & 3 & 21.4 & 1 & 25 & & & 11 & 26.2 \\
\hline Risk assessment and safety planning & 10 & 83.3 & 11 & 78.6 & 2 & 50 & 11 & 91.7 & 34 & 81 \\
\hline N per country/territory & 12 & & 14 & & 4 & & 12 & & & \\
\hline
\end{tabular}

Note: $\quad \mathrm{N}=42$.

*More than one option could be ticked.

Other supports that were reported by the respondents were as follows:

- Finland: one service provider offered therapy for the children of the clients.

- Sweden: one programme reported that their support service offered shelter for women.

- Denmark: one programme offered individual counselling.

\subsubsection{Safety measures in the event of victim support}

Programmes providing support for the victim from their own organisation $(n=36)$ were asked to specify what safety measures they take. All the service providers but one $(n=35,91.7 \%)$ reported that the safety measure they take is to offer support persons to the perpetrator and victim separately. Furthermore, some of these service providers also take the safety measure of avoiding contact between the perpetrator and victim if this contact is not wanted by the victim $(n=13 ; 36.1 \%)$.

\section{Table 46: Safety measures}

\begin{tabular}{|c|c|c|c|c|c|c|c|c|c|c|}
\hline & \multicolumn{2}{|c|}{ Finland } & \multicolumn{2}{|c|}{ Sweden } & \multicolumn{2}{|c|}{ Denmark } & \multicolumn{2}{|c|}{ Norway } & \multicolumn{2}{|c|}{ Total } \\
\hline & $\mathbf{F}$ & $\%$ & $\mathbf{F}$ & $\%$ & $\mathbf{F}$ & $\%$ & $\mathbf{F}$ & $\%$ & $F^{*}$ & $\%$ * \\
\hline No unwanted contact between perpetrator and victim & 7 & 70 & 5 & 50 & 1 & 25 & & & 13 & 36.1 \\
\hline Separate support persons for perpetrator and victim & 9 & 90 & 12 & 100 & 2 & 50 & 12 & 100 & 35 & 91.7 \\
\hline N per country & 10 & & 10 & & 4 & & 12 & & & \\
\hline
\end{tabular}

Note: $\quad \mathrm{N}=36$.

* More than one option could be ticked. 
In the "others" answers, Sweden reported that in one programme (6\%) the crisis centre for women is in a separate location, and in one (6\%) other programme, they (victim and perpetrator) had meetings on different dates/times.

In Denmark one service provider stated to undertake safety measures, but it did not specify which ones.

\subsubsection{Coordination with the victim support service}

All the service providers $(n=50)$ were asked what kind of coordination they had with victim support services. As shown in Table 47, very few programmes $(n=4 ; 8.7 \%)$ reported having no coordination with the victim support service. Most of the programmes $(n=17 ; 37 \%)$ reported coordination through a case-oriented exchange of information, though only in cases where this was needed by the situation. A few programmes $(n=12 ; 26.1 \%)$ reported a collaboration through a regular case-oriented exchange of information. Moreover, all the countries/territories $(n=15 ; 54.4 \%)$ had a service provider that coordinated with the victim support service through joint planning and decision-making between both services.

Table 47: Coordination with victim support service

\begin{tabular}{|c|c|c|c|c|c|c|c|c|c|c|}
\hline & \multicolumn{2}{|c|}{ Finland } & \multicolumn{2}{|c|}{ Sweden } & \multicolumn{2}{|c|}{ Denmark } & \multicolumn{2}{|c|}{ Norway } & \multicolumn{2}{|c|}{ Total } \\
\hline & $\mathbf{F}$ & $\%$ & $\mathbf{F}$ & $\%$ & $\mathbf{F}$ & $\%$ & $\mathbf{F}$ & $\%$ & F* & $\% *$ \\
\hline Joint planning and decision making & 5 & 38.5 & 6 & 35.2 & 2 & 50 & 12 & 100 & 15 & 54.4 \\
\hline $\begin{array}{l}\text { Case-oriented exchange of information: } \\
\text { regularly }\end{array}$ & 5 & 38.5 & 6 & $35 \cdot 3$ & & & 1 & 8.3 & 12 & 26.1 \\
\hline $\begin{array}{l}\text { Case-oriented exchange of information: } \\
\text { if required }\end{array}$ & 6 & 46.2 & 8 & 47.1 & 3 & 75 & & & 17 & 37 \\
\hline No coordination & 1 & 7.7 & 2 & 11.8 & 1 & 25 & & & 4 & 8.7 \\
\hline N per country & 13 & & 17 & & 4 & & 12 & & & \\
\hline
\end{tabular}

Note: $\quad \mathrm{N}=46$ (Åland, Iceland, the Faroe Islands and Greenland did not answer this question). *More than one option could be ticked

The "other" types of coordination processes, in Finland two service providers reported that they undertake an exchange of information only if the client gives permission. And in Sweden one programme was coordinated through team supervision, and one was coordinated through contact when necessary.

\subsubsection{Information exchanged with victim support services}

All the programmes $(n=50)$ were asked what kind of information they exchange with victim support services. The most often exchanged information $(n=16 ; 47.1 \%)$ was information about high-risk situations, while exchange information about repeated abuse by the client, and about the history of violence was equally common ( $n=10$; 29.4\%). Finally, the option "others" also received several responses, though only 
Finland specified what other information is exchanged, with one programme reporting information about couple therapy involvement was exchanged.

Table 48: Information exchanged with victim support serv

\begin{tabular}{|c|c|c|c|c|c|c|c|c|}
\hline & \multicolumn{2}{|c|}{ Finland } & \multicolumn{2}{|c|}{ Sweden } & \multicolumn{2}{|c|}{ Denmark } & \multicolumn{2}{|c|}{ Total } \\
\hline & $\mathbf{F}$ & $\%$ & F & $\%$ & $\mathbf{F}$ & $\%$ & $F^{*}$ & $\% *$ \\
\hline Repeated abuse by client & 2 & 15.4 & 6 & 35 & 2 & 50 & 10 & 29.4 \\
\hline History of violence & 2 & 15.4 & 6 & 35 & 2 & 50 & 10 & 29.4 \\
\hline High-risk situation & 7 & 53.9 & 6 & 35 & 3 & 75 & 16 & 47.1 \\
\hline No information is exchanged & 4 & 30.8 & 6 & 35 & & & 10 & 29.4 \\
\hline N per country/territory & 13 & & 17 & & 4 & & & \\
\hline
\end{tabular}

Note: $\mathrm{N}=34$.

*More than one option could be ticked.

\subsection{Section G: quality assurance}

\subsubsection{Measures of quality assurance}

a) Team sessions

All the programmes $(n=50)$ were asked what measures of quality assurance do they have in their services, and $88 \%$ reported having some team sessions $(n=44)$. Most of the programmes $(n=35 ; 79.6 \%)$ reported that they have weekly team sessions. Some of those also had monthly team sessions $(n=4 ; 9.1 \%)$ either alone or alongside the possibility for weekly team sessions.

Table 49: Measures of quality assurance: team sessions

\begin{tabular}{|c|c|c|c|c|c|c|c|c|c|c|c|c|c|c|c|}
\hline & & \multicolumn{2}{|c|}{ Finland } & \multicolumn{2}{|c|}{ Iceland } & \multicolumn{2}{|c|}{ Sweden } & \multicolumn{2}{|c|}{ Denmark } & \multicolumn{2}{|c|}{ Greenland } & \multicolumn{2}{|c|}{ Norway } & \multicolumn{2}{|c|}{ Total } \\
\hline & & F & $\%$ & $F$ & $\%$ & $\mathbf{F}$ & $\%$ & $\mathbf{F}$ & $\%$ & $\mathbf{F}$ & $\%$ & $\mathbf{F}$ & $\%$ & $F$ & $\%$ \\
\hline \multirow{3}{*}{$\begin{array}{l}\text { Team } \\
\text { Sessions }\end{array}$} & Weekly & 10 & 71.4 & 1 & 100 & 9 & 69.2 & 3 & 75 & 1 & 100 & 11 & 91.7 & 35 & 79.6 \\
\hline & Monthly & 2 & 15.4 & & & 1 & 7.7 & & & & & 1 & 8.3 & 4 & 9.1 \\
\hline & Other frequency & 2 & $15 \cdot 4$ & & & 3 & 23.1 & & & & & & & 5 & 11.4 \\
\hline $\begin{array}{l}\mathrm{N} \text { per } \\
\text { country }\end{array}$ & & 14 & & 1 & & 13 & & 3 & & 1 & & 12 & & & 100 \\
\hline
\end{tabular}

Note: $\quad \mathrm{N}=44$.

In the section "Other frequency", Finland had one service provider that had team sessions fortnightly and another that reported having no team sessions. In Sweden, two service providers reported team sessions both weekly and monthly, and another programme reported having team sessions at a non-specified frequency. 
b) Supervision

In terms of the frequency of supervision, $78 \%(n=39)$ of the programmes reported having some supervision activities. The majority $(n=35 ; 89.7 \%)$ had supervision taking the form of the continuous education of staff.

Table 50: Measures of quality assurance: supervision

\begin{tabular}{|c|c|c|c|c|c|c|c|c|c|c|c|c|c|}
\hline & & \multicolumn{2}{|c|}{ Finland } & \multicolumn{2}{|c|}{ Iceland } & \multicolumn{2}{|c|}{ Sweden } & \multicolumn{2}{|c|}{ Denmark } & \multicolumn{2}{|c|}{ Norway } & \multicolumn{2}{|c|}{ Total } \\
\hline & & $\mathbf{F}$ & $\%$ & $\mathbf{F}$ & $\%$ & $F$ & $\%$ & F & $\%$ & F & $\%$ & $F$ & $\%$ \\
\hline \multirow[t]{2}{*}{$\begin{array}{l}\text { Supervision, } \\
\text { frequency }\end{array}$} & $\begin{array}{l}\text { Continuing education } \\
\text { of staff }\end{array}$ & 10 & 83.3 & 1 & 100 & 9 & 90 & 3 & 75 & 12 & 100 & 35 & 89.7 \\
\hline & Others & 2 & 16.7 & & & 1 & 10 & 1 & 25 & & & 5 & 10.2 \\
\hline $\begin{array}{l}\mathrm{N} \text { per countryl } \\
\text { territory }\end{array}$ & & 12 & & 1 & & 10 & & 4 & & 12 & & & 100 \\
\hline
\end{tabular}

Note: $\quad \mathrm{N}=39$.

Regarding "other" kinds of supervision activities:

- In Finland two service providers reported having individual supervision, and one reported continuous self-evaluation.

- In Denmark one service provider reported having group and individual supervision twice a month.

\subsubsection{Documentation and reporting system}

All the programmes $(n=50)$ were asked what kind of documentation and reporting system they followed in their facilities. The majority of the programmes reported undertaking annual activity reports $(n=38,79.2 \%)$ (which was undertaken by some programmes in all the Nordic countries) and annual statistics $(n=36 ; 75 \%)$. More than half of the programmes $(n=29 ; 60.4 \%)$ used standardized documentation of social statistics data on clients as a report system. Finally, $56.3 \%(n=27)$ used case-oriented, standardized documentation of the work, while $52.1 \%(n=25)$ used case-oriented nonstandardized documentation of the work (notes etc.). 
Table 51: Documentation

\begin{tabular}{|c|c|c|c|c|c|c|c|c|c|c|c|c|c|c|}
\hline & \multicolumn{2}{|c|}{ Finland } & \multicolumn{2}{|c|}{ Iceland } & \multicolumn{2}{|c|}{ Sweden } & \multicolumn{2}{|c|}{ Denmark } & \multicolumn{2}{|c|}{$\begin{array}{l}\text { Faroe } \\
\text { Islands }\end{array}$} & \multicolumn{2}{|c|}{ Norway } & \multicolumn{2}{|c|}{ Total } \\
\hline & F & $\%$ & $\mathrm{~F}$ & $\%$ & $\mathrm{~F}$ & $\%$ & $\mathbf{F}$ & $\%$ & F & $\%$ & $\mathbf{F}$ & $\%$ & $F^{*}$ & $\% *$ \\
\hline $\begin{array}{l}\text { Standardized documentation of social } \\
\text { statistic data of clients }\end{array}$ & 8 & 61.5 & & & 6 & 35.1 & 3 & 75 & & & 12 & 100 & 29 & 60.4 \\
\hline $\begin{array}{l}\text { Case-oriented, standardized } \\
\text { documentation of work }\end{array}$ & 7 & 53.9 & 1 & 100 & 4 & 23.5 & 3 & 75 & & & 12 & 100 & 27 & 56.3 \\
\hline $\begin{array}{l}\text { Case-oriented, non-standardized } \\
\text { documentation of work (notes etc.) }\end{array}$ & 5 & 38.5 & & & 7 & 41.2 & 1 & 25 & & & 12 & 100 & 25 & 52.1 \\
\hline Annual activity report & 11 & 84.6 & 1 & 100 & 9 & 52.9 & 4 & 100 & 1 & 100 & 12 & 100 & 38 & 79.2 \\
\hline Annual statistics & 8 & 61.5 & 1 & 100 & 12 & 70.6 & 3 & 75 & & & 12 & 100 & 36 & 75 \\
\hline $\mathrm{N}$ per country/territory & 13 & & 1 & & 17 & & 4 & & 1 & & 12 & & & \\
\hline
\end{tabular}

Note: $\quad \mathrm{N}=48$.

*More than one option could be ticked.

Figure 35: Documentation

DOCUMENTATION AND REPORTING SYSTEM AVAILABLE

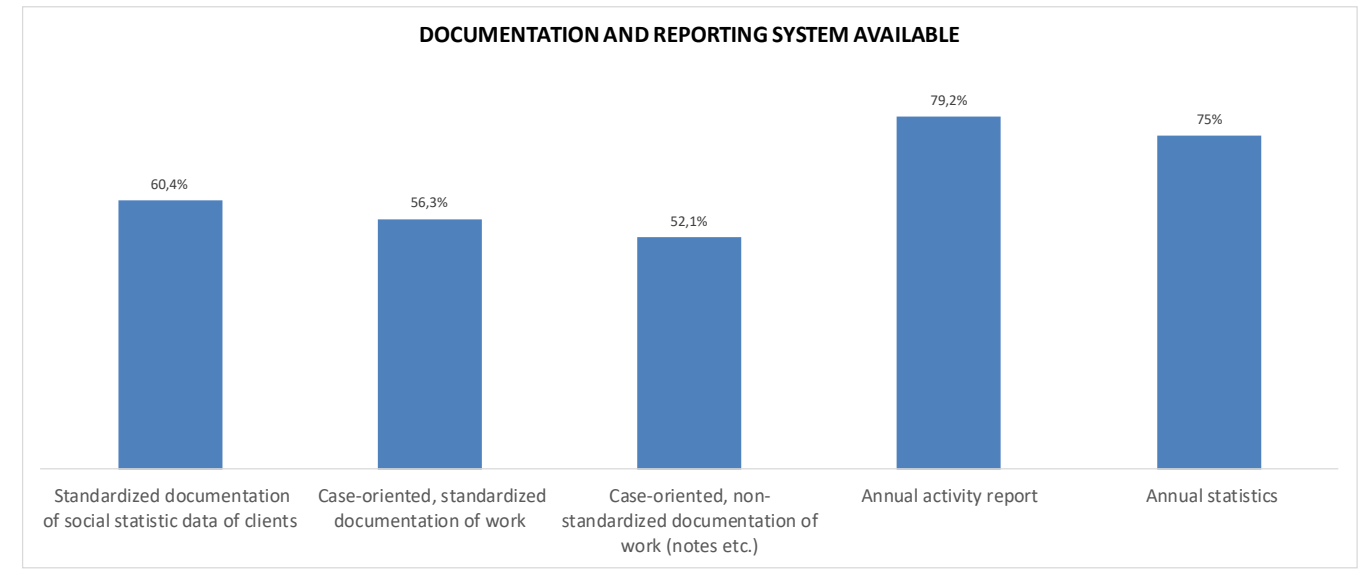

In the "others" section, in Finland one service provider reported a standardized questionnaire was used during the process. Sweden reported one programme (6\%) that used interviews with the partner/ex-partner at the end of the treatment.

\subsubsection{Measurement of outcomes}

The vast majority of programmes reported that they measure outcomes ( $n=37 ; 82.2 \%)$. Half of Swedish service providers $(n=8)$ and Danish service providers $(n=2)$ reported measuring outcomes. In Iceland and the Faroe Islands the only service providers in each country/territory reported that they measured outcomes $(100 \% ; n=1)$. Finally, in Norway and Finland, all the service providers reported that they measured outcomes (100\%; $n=12 ;$ and $n=13 ; 100 \%$ respectively). 
Table 52: Outcome measurement

\begin{tabular}{|c|c|c|c|c|c|c|c|c|c|c|c|c|c|c|}
\hline & \multicolumn{2}{|c|}{ Finland } & \multicolumn{2}{|c|}{ Iceland } & \multicolumn{2}{|c|}{ Sweden } & \multicolumn{2}{|c|}{ Denmark } & \multicolumn{2}{|c|}{$\begin{array}{l}\text { Faroe } \\
\text { Islands }\end{array}$} & \multicolumn{2}{|c|}{ Norway } & \multicolumn{2}{|c|}{ Total } \\
\hline & $\mathbf{F}$ & $\%$ & $\mathbf{F}$ & $\%$ & $\mathrm{~F}$ & $\%$ & $\mathrm{~F}$ & $\%$ & $\mathbf{F}$ & $\%$ & $\mathbf{F}$ & $\%$ & $\mathbf{F}$ & $\%$ \\
\hline Yes & 13 & 100 & 1 & 100 & 8 & 50 & 2 & 100 & 1 & 100 & 12 & 100 & 37 & 82.2 \\
\hline No & & & & & 8 & 50 & & & & & & & 8 & 17.8 \\
\hline N per country & 13 & & 1 & & 16 & & 2 & & 1 & & 12 & & 45 & 100 \\
\hline
\end{tabular}

Note: $\quad \mathrm{N}=47$.

Figure 36: Outcome measurement

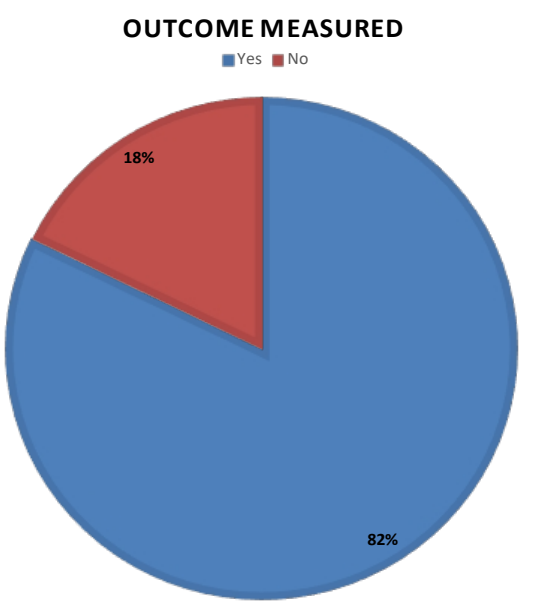

\subsubsection{Points at which the outcome is measured}

Service providers measuring outcomes $(n=37 ; 82.2 \%)$ were asked about the point at which the outcomes were measured. Most of the programmes $(n=28 ; 75.7 \%)$ reported that they measure outcomes when the client finishes the programme, whereas a few $(n=7 ; 18.9 \%)$ measured outcomes at the first follow-up (between 3 and 6 months after finishing the programmes). A few more $(n=15 ; 40.5 \%)$ measure outcomes at a second follow-up between 12 and 24 months after finishing the programme. This second follow-up is bigger, since in Norway, nearly all the service providers $(n=11)$ measure outcomes at the second follow-up, even if not measuring outcomes at the first one. 
Table 53: Point at which the outcome is measured

\begin{tabular}{|c|c|c|c|c|c|c|c|c|c|c|c|c|c|c|}
\hline & \multicolumn{2}{|c|}{ Finland } & \multicolumn{2}{|c|}{ Iceland } & \multicolumn{2}{|c|}{ Sweden } & \multicolumn{2}{|c|}{ Denmark } & \multicolumn{2}{|c|}{ Greenland } & \multicolumn{2}{|c|}{ Norway } & \multicolumn{2}{|c|}{ Total } \\
\hline & $\mathbf{F}$ & $\%$ & F & $\%$ & $F$ & $\%$ & $\mathbf{F}$ & $\%$ & $\mathbf{F}$ & $\%$ & $\mathbf{F}$ & $\%$ & $F^{*}$ & $\% *$ \\
\hline When client finishes the programme & 11 & 84.6 & 1 & 100 & 1 & 12.5 & 2 & 100 & 1 & 100 & 12 & 100 & 28 & 75.7 \\
\hline $\begin{array}{l}\text { At follow-up, } X X X \text { months after finishing } \\
\text { the programme }\end{array}$ & 3 & 23.1 & & & 2 & 25 & & & 1 & 100 & 1 & 8.3 & 7 & 18.9 \\
\hline $\begin{array}{l}\text { At a second follow-up, } X X X \text { months after } \\
\text { finishing the programme }\end{array}$ & 2 & 15.4 & & & 1 & 12.5 & 1 & 50 & & & 11 & 91.7 & 15 & 40.5 \\
\hline Others & & & & & & & 1 & 50 & & & & & 1 & 100 \\
\hline N per country & 13 & & 1 & & 8 & & 2 & & 1 & & 12 & & & 2.7 \\
\hline
\end{tabular}

Note: $\mathrm{N}=37$.

*More than one option could be ticked.

\subsubsection{Specific measuring of outcomes}

Service providers that measured outcomes $(n=37)$ were asked what outcomes they measured. The main outcome measured was the continuation of non-violence and/or a decrease of violence $(n=37 ; 94.6 \%)$, improvement in the client's quality of life $(n=32$; $83.8 \%)$, and improvement in client's communication skills and conflict resolution skills $(n=26 ; 70.3 \%)$. Items referring to the partner situation received less prominence: Improvement in the partner's feeling of safety $(n=25 ; 67.6 \%)$, improvement in the partner's quality of life $(n=11 ; 29.7 \%)$, and improvement in other aspects of the relationship (e.g. communication) $(n=4 ; 10.8 \%)$.

Table 54: Specific measure of outcome

\begin{tabular}{|c|c|c|c|c|c|c|c|c|c|c|c|c|c|c|c|}
\hline & \multicolumn{2}{|c|}{ Finland } & \multicolumn{3}{|c|}{ Iceland } & \multicolumn{2}{|c|}{ Sweden } & \multicolumn{2}{|c|}{ Denmark } & \multicolumn{2}{|c|}{$\begin{array}{l}\text { Faroe } \\
\text { Islands }\end{array}$} & \multicolumn{2}{|c|}{ Norway } & \multicolumn{2}{|c|}{ Total } \\
\hline & $\mathbf{F}$ & $\%$ & $\mathbf{F}$ & & $\%$ & $\mathbf{F}$ & $\%$ & $\mathbf{F}$ & $\%$ & $\mathbf{F}$ & $\%$ & $\mathbf{F}$ & $\%$ & $F^{*}$ & $\% *$ \\
\hline Non-violence / decrease of violence & 12 & 92.3 & & 1 & 100 & $\varepsilon$ & 100 & 2 & 100 & & 100 & 11 & 92 & 37 & 94.6 \\
\hline $\begin{array}{l}\text { Changes in attitudes and beliefs that } \\
\text { support violence }\end{array}$ & 9 & 69.2 & & & & 5 & 62.5 & 1 & 50 & & 100 & & & 16 & 43.2 \\
\hline $\begin{array}{l}\text { Improvement of client's communication } \\
\text { skills and conflict resolution skills }\end{array}$ & 8 & 61.5 & & & & 5 & 62.5 & 1 & 50 & & 100 & 11 & 92 & 26 & 70.3 \\
\hline Improvement of client's quality of life & 9 & 69.2 & & 1 & 100 & 7 & 87.5 & 2 & 100 & & 100 & 11 & 92 & 32 & 83.8 \\
\hline $\begin{array}{l}\text { Improvement of other aspects of the } \\
\text { relationship (e.g. communication) }\end{array}$ & & & & & & 4 & 50.0 & & & & & & & 4 & 10.8 \\
\hline Improvement of partner's feeling of safety & 9 & 69.2 & & 1 & 100 & 3 & $37 \cdot 5$ & 1 & 50 & & & 11 & 92 & 25 & 67.6 \\
\hline Improvement of partner's quality of life & 7 & $53 \cdot 9$ & & 1 & 100 & 1 & 12.5 & 2 & 100 & & & & & 11 & 29.7 \\
\hline N per country & 13 & & & 1 & & 8 & & 2 & & & 1 & 12 & & 152 & \\
\hline
\end{tabular}

Note: $\mathrm{N}=37$.

*More than one option could be ticked. 


\section{OUTCOME MEASURED}

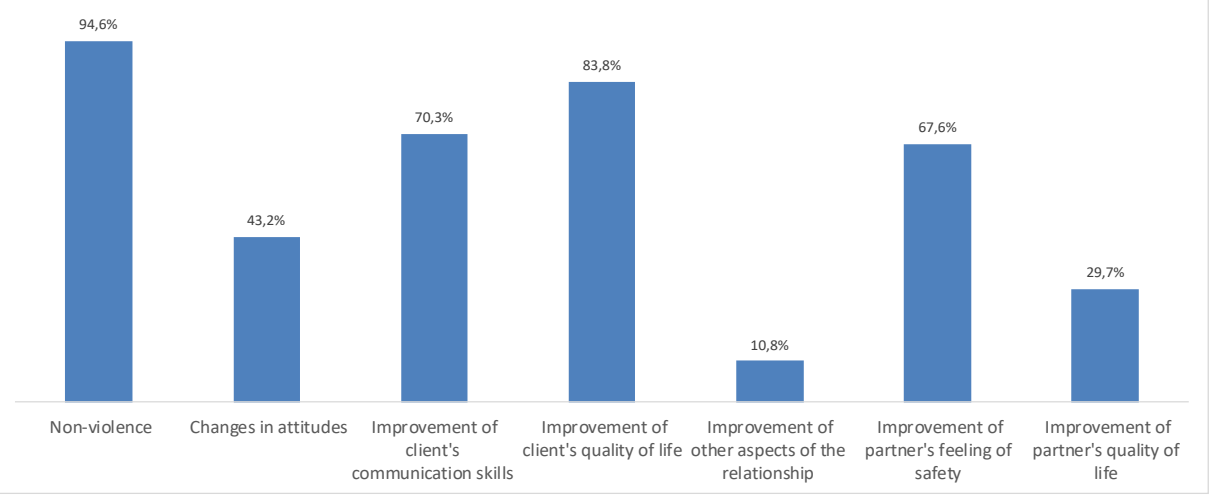

In the section "Others", the following information was given by each country/territory:

- Finland: Five service providers reported measuring the improvement of other aspects of a client's life; and one programme reporting measuring the perpetrator's experiences of the programme.

- Sweden: one programme reported measuring the improvement of the children's feelings of safety and another one measured the working-alliance with the therapist.

- Denmark: one programme reported measuring the level of anger and the level of risk.

- Norway: the SBM programme reported having no standardized measure for outcome (i.e. violent behaviour), but used the Global Assessment of Functioning (GAF).

\subsubsection{Instruments to measure outcomes}

The service providers measuring outcomes $(n=37)$ were asked to answer what instruments they used to measure outcomes. The most often used instruments were the client's self-assessment by interview $(n=30 ; 79 \%)$, and the client's self-assessment by questionnaire $(n=31 ; 81.6 \%)$. Also, measures relating to the partner's victim had some relevance: the partner's assessment by interview $(n=18 ; 47.4 \%)$ and the partner's assessment by questionnaire or inventory $(n=17 ; 44.7 \%)$. No programme reported using official reports (police, court etc.) as a measure of outcomes (however, the prison programmes in Finland, for example, did report using it, but they have not been included in this Final Report; for more information see the Finnish Country Report). 
Table 55: Instruments to measure outcome

\begin{tabular}{|c|c|c|c|c|c|c|c|c|c|c|c|c|c|c|c|c|}
\hline & \multicolumn{2}{|c|}{ Finland } & \multicolumn{2}{|c|}{ Iceland } & \multicolumn{2}{|c|}{ Sweden } & \multicolumn{2}{|c|}{ Denmark } & \multicolumn{2}{|c|}{$\begin{array}{l}\text { Faroe } \\
\text { Islands }\end{array}$} & \multicolumn{2}{|c|}{ Greenland } & \multicolumn{2}{|c|}{ Norway } & \multicolumn{2}{|c|}{ Total } \\
\hline & $\mathbf{F}$ & $\%$ & $\mathbf{F}$ & $\%$ & F & $\%$ & $F$ & $\%$ & $\mathbf{F}$ & $\%$ & $\mathbf{F}$ & $\%$ & $\mathbf{F}$ & $\%$ & $F^{*}$ & $\% *$ \\
\hline $\begin{array}{l}\text { Client's self- } \\
\text { assessment by } \\
\text { interview }\end{array}$ & 8 & 61.5 & 1 & 100 & 6 & 75 & 2 & 100 & 1 & 100 & 1 & 100 & 11 & 91.7 & 30 & 78.9 \\
\hline $\begin{array}{l}\text { Client's self- } \\
\text { assessment by } \\
\text { questionnaire }\end{array}$ & 12 & 92.3 & & & 5 & 62.5 & 2 & 100 & & & 1 & 100 & 11 & 91.7 & 31 & 81.6 \\
\hline $\begin{array}{l}\text { Facilitator's } \\
\text { assessment of client } \\
\text { by psychological } \\
\text { inventory }\end{array}$ & 4 & 30.8 & 1 & 100 & 1 & 12.5 & 1 & 50 & & & 1 & 100 & & & 8 & 21.1 \\
\hline $\begin{array}{l}\text { Facilitator's } \\
\text { assessment of client } \\
\text { by other questionnaire }\end{array}$ & 2 & 15.4 & & & 2 & 25 & 1 & 50 & & & 1 & 100 & 1 & 8.3 & 7 & 18.4 \\
\hline $\begin{array}{l}\text { Facilitator's } \\
\text { assessment of client } \\
\text { using internal } \\
\text { documentation and } \\
\text { minutes }\end{array}$ & & & 1 & 100 & 3 & 37.5 & 1 & 50 & & & 1 & 100 & & & 6 & 15.8 \\
\hline $\begin{array}{l}\text { Partner's assessment } \\
\text { by interview }\end{array}$ & 4 & 30.8 & 1 & 100 & 1 & 12.5 & 1 & 50 & & & & & 11 & 91.7 & 18 & 47.4 \\
\hline $\begin{array}{l}\text { Partner's assessment } \\
\text { by questionnaire or } \\
\text { inventory }\end{array}$ & 3 & 23.1 & 1 & 100 & 1 & 12.5 & 1 & 50 & & & & & 11 & 91.7 & 17 & 44.7 \\
\hline $\begin{array}{l}\text { Official reports (police, } \\
\text { court etc.) }\end{array}$ & & & & & & & & & & & & & & & 0 & 0 \\
\hline $\mathrm{N}$ per country/territory & 13 & & 1 & & 8 & & 2 & & 1 & & & & 12 & & 118 & \\
\hline
\end{tabular}

Note: $\mathrm{N}=38$ (Greenland has also answered this question).

* More than one option could be ticked. 
Figure 38: Instruments to measure outcome

INSTRUMENTS TO MEASURE OUTCOME

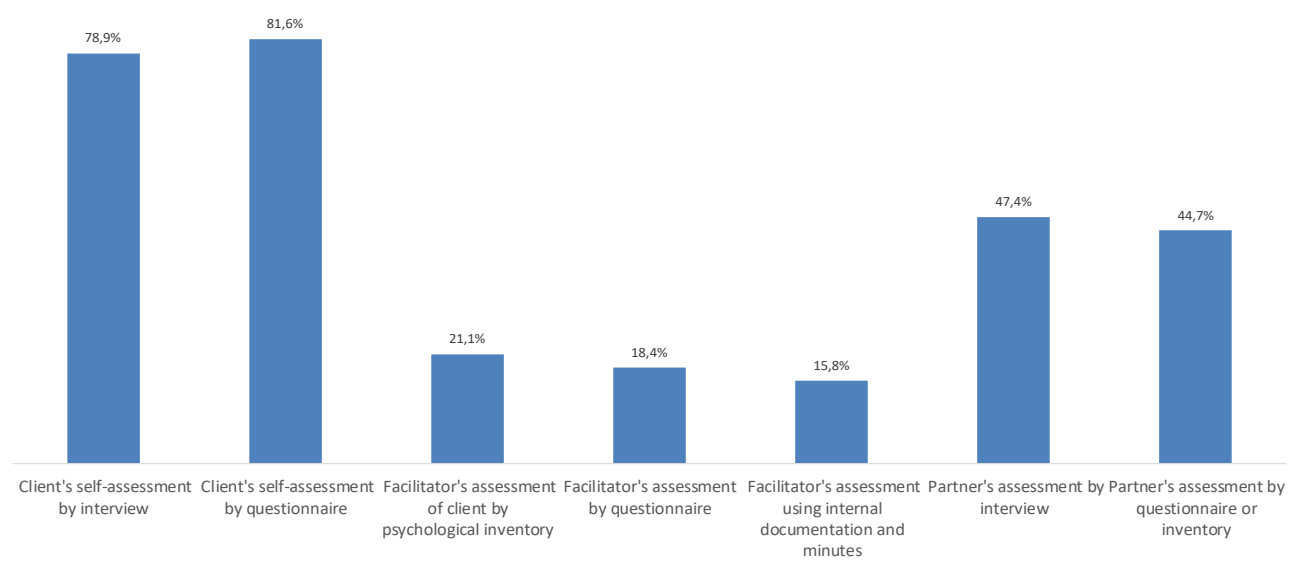

Service providers were asked to specify which standardized instruments they use:

- In Sweden the standardized instruments used varied widely across the programmes, varying from CTS-2, FREDA, IVIN, MMEA, SCL-90, the Symptoms checklist, the Scott Miller Outcome Rating Scale, CSQ-8 and a checklist developed by a student at Malmö University.

- In Denmark: the services used the Millon Clinical Multiaxial Inventory (MCMI), the Revised Conflict Tactics Scales (CTS2), the Symptom Checklist-9o-Revised (SCL9o-R), the Novaco Anger Scale and Provocation Inventory (NAS-PI), the Inventory of Interpersonal Problems (IIP), the SARA risk assessment and SAM, the Feedback Informed Treatment (FIT). An external evaluation of the work is further used for quality assurance.

- In Norway: The ATVT-study used two instruments to measure outcome: The standardized instrument was the Outcome Questionnaire - $\mathrm{OQ}_{45}$ (Lambert et al., 1996). The instrument used to measure violence and alcohol substance abuse is a non-standardized instrument, but was developed by the ATV. The shortened version of the Violence Questionnaire - VO (Askeland, Evang, \& Heir, 2011) was administered as an outcome measure in the ATVT-study. SBM used a violence questionnaire developed by SBM.

\subsubsection{Evaluation of work}

Most of the programmes $(n=38 ; 77.55)$ undertook internal evaluations of their work, while less than half $(n=24 ; 48.98 \%)$ used an external evaluation. Just $10.2 \%(n=5)$ of the programmes did not evaluate their work. 
Table 56: Evaluation of work

\begin{tabular}{|c|c|c|c|c|c|c|c|c|c|c|c|c|c|c|c|c|}
\hline & \multicolumn{2}{|c|}{ Finland } & \multicolumn{2}{|c|}{ Iceland } & \multicolumn{2}{|c|}{ Sweden } & \multicolumn{2}{|c|}{ Denmark } & \multicolumn{2}{|c|}{$\begin{array}{l}\text { Faroe } \\
\text { Islands }\end{array}$} & \multicolumn{2}{|c|}{ Greenland } & \multicolumn{2}{|c|}{ Norway } & \multicolumn{2}{|c|}{ Total } \\
\hline & $\mathbf{F}$ & $\%$ & $\mathbf{F}$ & $\%$ & $\mathbf{F}$ & $\%$ & $\mathbf{F}$ & $\%$ & $\mathbf{F}$ & $\%$ & $\mathbf{F}$ & $\%$ & $\mathbf{F}$ & $\%$ & $F^{*}$ & $\% *$ \\
\hline Internal evaluation & 12 & 92.3 & & & 9 & 52.9 & 3 & 75 & 1 & 100 & 1 & 100 & 12 & 100 & 38 & 77.6 \\
\hline External evaluation & 4 & 30.8 & 1 & 100 & 4 & 23.5 & 2 & 50 & 1 & 100 & 1 & 100 & 12 & 100 & 24 & 49 \\
\hline No evaluation & & & & & 5 & 29.41 & & & & & & & & & 5 & 10.2 \\
\hline $\begin{array}{l}\text { N per countryl } \\
\text { territory }\end{array}$ & 13 & & 1 & & 17 & & 4 & & 1 & & 1 & & 12 & & & \\
\hline
\end{tabular}

Note: $\quad \mathrm{N}=49$.

* More than one option could be ticked.

Regarding the "Others" section, service providers were asked to specify what kind of external evaluation they undertook:

- Finland had one service provider who reported carrying out an audit every 10 ears, while another reported using an evaluation of the Jussi-work, which is available online. Finally another programme reported an agreement with Turku University for future research in which their work will be evaluated.

- The service provider in Iceland reported an assessment carried out by ICE-CCFR, a research and educational institution within the Department of Social Work located at the Social Science Research Institute at the University of Iceland, on behalf of the government agency the Centre for Gender Equality in 2014.

- In Norway, the ATV services have an ongoing research project in cooperation with NKVTS, the ATVT-study, which started in January 2010. The study is a prospective process- and outcome study of therapy with men who seek help for violence against their partner. The ATVT-study has follow-ups with the client and partner or ex-partner before, during and after completing the treatment (18 months after treatment).

\subsubsection{Challenges for the future}

The final question in the questionnaires was an open-ended question asking about participant's concerns regarding the three main future challenges in their work.

Among the most often mentioned challenges were:

- Funding, which is not usually permanent, and is sometimes tied to a specific number of sessions (Finland). Funding is scarce in general for all Nordic countries/territories, and it was a concern raised by many of the service providers. This situation also connects to staff being part-time and non-permanent. Moreover, the funding instability is a challenge for long-term planning and improvement of current programmes. 
- Widening the range of services offered to cover abused children, female perpetrators, perpetrators with another sexual orientation than heterosexual, ethnic minorities, immigrants, etc. was also a challenge mentioned by most of the programmes.

- Solving the geographic inequality in access to services, that is, the challenge of developing an equal service for all residents regardless of residence.

- Training and education to develop and apply different methods and also the evaluation of the programme. In this context, the need to develop post-treatment pathways for those who relapse was mentioned.

- Increased cooperation and collaboration with other institutions, for example, to better integrate the work with the services offered to the family, especially from the point of view of the children. Also, the need to increase referrals from other agencies and the health care system was mentioned by many service providers.

- Some challenges mentioned less often were: (a) increasing prevention tasks, such as marketing the service better at a preventive stage, (b) working with attitudes regarding gender equality, (c) raising awareness on the effects of psychological violence and the importance of stopping the transmission of violence from one generation to another. 



\section{Conclusions}

In this section a summary and conclusions of the main results will be presented. Moreover, results will be compared with the results from the recent study conducted by Geldschläger and colleagues (2014), whom used a very similar questionnaire to analyse the service providers" quality at the European level. Our results will also be discussed in light of the European standards reviewed in the Introduction. It is worth mentioning that the study of Geldschläger and colleagues (2014) included data from various European countries, including some of the Nordic countries that are part of the present study. The Nordic countries included in Geldschläger and colleagues (2014) study were: Denmark (which represented the $0.7 \%$ of the total sample), Finland (which represented the $2.2 \%$ of the total sample), Norway (which represented the $1.5 \%$ of the total sample), and Sweden (which represented the $3 \%$ of the total sample). The Nordic countries taken altogether represented the $7.4 \%$ of the total sample of their study. Therefore, the Nordic results of their study represented a very small amount of the total sample, and thus, influenced very minimally the final results of the study. For this reason, comparison can be made of their results with the ones obtained in the current study; Appendix 2 provides a table summary of this section.

\subsection{Basic Information and characteristics of the programmes (location, staff, and funding)}

Half of the programmes were organised by a wider organization and half by an NGO (especially relevant in the case of Finland, where all programmes were part of an NGO; Norway in which most of the programmes (91\%) were organised by an NGO, and Denmark in which half were).

Moreover, most of the programmes were located in an urban area (only Sweden had one programme in a rural area, and 3 in a peri-urban area; while Norway had a couple of programmes in a peri-urban area $(n=2)$ ), while more than half of the programmes can be considered as "very old", whereas one in four can be considered as "new". Sweden and Denmark present the most varied results in all the categories, while Finland, Iceland, and Norway had mostly "very old" programmes. Comparing these results with the ones obtained at the European level, programmes in the Nordic countries/territories seem to be older than those in Europe, which were more evenly distributed over the four categories, with a slight over-representation of the young programmes and a slight under representation of the new (Geldschläger, et al., 2014)

Regarding the gender of the staff, there seem to be slightly more female staff members. One third of the staff seem to work part-time, which is especially relevant in Finland (more than 40\%), Iceland (100\%), Sweden (more than 30\%) and Denmark (more 
than 20\%), while in Norway all the staff worked full-time. Finally, most of the staff were psychologists, although some countries do not follow this trend, with Sweden having more social workers and Finland having more psychotherapists.

Regarding funding, European funding was scarce (Åland being the only country receiving EU funding), while the main funding was typically municipal and governmental in origin. The Faroe Islands and Greenland reported solely project-based funding, while Denmark reported more project funding (75\%) than permanent funding (25\%). Indeed, for ATV services in Denmark the funding ended in October 2016 and it likely had to close. This funding was reported mostly to be permanent, however most of it was reviewed on a yearly or two-year basis. A client contribution existed in less than half of the programs and was concentrated in Norway and Iceland (all of their programmes).

These results indicate that work still needs to be done to achieve the European standards reviewed in the Introduction, especially the one regarding diversity and fair access, where services should be available free of charge and be equitably distributed across the geography of the country. Moreover, according to the European standard referred to as a "coordinated response", a long-term commitment in terms of financial resources is required, and this does not appear to have been accomplished.

Regarding staff training, the questionnaire did not clarify beyond training in psychology, for example, that the staff would also be trained on the nature of violence. It is even less clear if they possess the cultural and linguistic skills that would enable them to work with a wide diversity of men attending such programmes (Council of Europe, 2011).

Finally, it is important to note that these needs were already emphasized by the service providers when reporting on the main challenges of their work. Therefore, the funding was a concern raised by all the service providers, which might provoke instability in staffing and which might challenge the long-term planning and improvement of current programmes. Moreover, solving the geographic inequality in access to the services and the need for training and education to develop and apply different methods were also mentioned by nearly all the service providers.

\subsection{Cooperation and context}

All the service providers in all the countries reported that they collaborate with other institutions, most often (more than $80 \%$ of the programmes) with social services, family services, and the police. Collaborations mentioned less often were with the emergency units and the prosecutor ( $2 \%$ and $8 \%$, respectively). It is remarkable that collaborations with health services (hospitals, and general practice doctors), judicial services (criminal and civil court, prosecutor), and women's services (women's shelters, and counselling services) were still very low (around a third of the programmes reported these kinds of collaborations, with the exception of women's shelters, which some two thirds reported collaboration, and women's counselling services, with around half reporting collaboration with these). Especially relevant was the case of Iceland, Denmark, the 
Faroe Islands and Greenland, where there was no cooperation with women's counselling services. On the other hand, in Norway nearly all service providers collaborated with women's counselling services, judicial services, and general practice doctors, whereas in Finland and Sweden, this was found in around the half the programmes. Sweden and Norway are the main countries where cooperation with judicial services is done (in the Faroe Islands and Denmark, cooperation is only with the criminal court).

Most of the programmes (more than $80 \%$ ) reported being part of an interinstitutional alliance on domestic violence; just two countries had programmes that were not part of an inter-institutional alliance (Sweden, and Denmark). As for Finland, Iceland, the Faroe Islands and Norway, all the service providers were part of an interinstitutional alliance against domestic violence. In the Europe context, the number of programmes that were part of an inter-institutional alliance was slightly lower (75\%) (Geldschläger, et al., 2014). In terms of cooperation with other institutions, in the Nordic countries/territories collaboration with the women's counselling services was very low (with about one in three programmes collaborating with them), while programmes in Europe collaborate more often with these services (two out of three programmes) (Geldschläger, et al., 2014).

Nearly all the programmes offered services for male perpetrators, but many also offered services for female and same-sex perpetrators and female and male victims of violence (around three out of four programmes). About half of the programmes also offered services for sexual offenders, while the Istanbul Convention stipulates that programmes for domestic violence perpetrators and sexual violence perpetrators should be administered separately. However, there are important connections between these types of programmes, consistent with the practice of working across different forms of violence against women. For example, results at the European level showed that $32.1 \%$ of the programmes also offered interventions for sex offenders (Geldschläger, et al., 2014). Services for child witnesses of violence were the more commonly offered in the Nordic countries/territories ( $41.2 \%$ in the Nordic countries vs $37.3 \%$ in the European context); these services were most commonly offered in Denmark (75\%), Sweden (41.2\%), and Greenland (100\%).

The findings from the cooperation and context section showed that programmes follow a "systems approach" to a quite high extent, as all the services cooperate with other institutions and usually they collaborate with more than one. Moreover, many programmes also reported being part of an inter-institutional alliance on domestic violence. However, in light of the Istanbul Convention and European standards, cooperation with support service for victims (cooperation with women's counselling services and women's shelters) should be increased and emphasized in order to increase and prioritize the safety of the (ex-) partner.

These needs were also stated by the service providers as the main challenges, with an emphasis on including the perspective of children, both in terms of widening the services offered by the programmes to also cover abused children, and also in terms of increasing cooperation and collaboration with family services, which though cooperation 
with them was quite high ( $84 \%)$, the challenge to better integrate the work with family services was especially mentioned, particularly from the point of view of the children.

\subsection{Referral and intake}

Most perpetrators are self-referred or referred by other agencies (mainly by welfare agencies and the police), while very few are referred by the court/justice system (just three programmes). Indeed, most of the programs do not have referrals from the court justice system. Results from the Europe context showed that some programmes excluded some kind of referrals or concentrated on a certain kind of referral (22\% work with court-mandated men only, and $19 \%$ do not work with court-referred men at all), but the majority of programmes worked with various kinds of referrals (Geldschläger, et al., 2014). Comparing these results, it seems that there are fewer court-mandated clients and fewer programmes with various types of referrals than in European programmes. For example, Åland and Greenland have voluntary self-referrals, while only Sweden (17.7\%), Norway (8.3\%) and Finland (7.1\%) reported any referrals from the court/justice system. Finally, Iceland (100\%), Sweden (52.9\%) and Norway (100\%) reported referrals from victim services.

Just four programmes (7.8\%) had no intake requirements (three in Finland and one in the Faroe Islands). The most common intake requirements (selected by more than half of the programmes) were "being alcohol and drug free", "being motivated to participate" and "being able to cognitively follow the programme". In the European context, a similar percentage of programmes had no intake requirements ( $7 \%)$. Moreover, "being alcohol and drug free" was also the main intake requirement, while the second most often mentioned were "not having mental disorders" (which was ranked fourth in the Nordic countries/territories), and having "sufficient language skills" (Geldschläger, et al., 2014). Therefore, it seems that in the Nordic countries, motivation takes on a special relevance (fourth place in the European results) regarding the intake requirements.

A few programmes (8\%) did not undertake any clearing phase during the intake procedure (Sweden and the Faroe Islands had some programmes that did not have any intake/clearing phase). Some $20 \%$ undertook an initial interview, while more than half reported an individual counselling phase before the group work commenced (in Finland, Åland, and Norway, all the programmes reported this individual counselling phase). Similarly, in the Europe context, $95 \%$ of the programmes had some intake procedure. The instruments used in the intake phase were not specified in the Nordic questionnaire, while many different instruments were used in the programmes (Geldschläger, et al., 2014).

The most often mentioned exclusion criteria were "being violent with group members or the facilitator/s" (90\%) and "continuing to be abusive with the (ex-) partner" (51.3\%). However, it should be noted that although half of the programmes considered the latter to be an exclusion criterion, most of the programmes considered the first item to be an exclusion criterion. A significant number of programmes (40\%) did not use any risk assessment instruments, with similar results obtained in the 
European context (Geldschläger, et al., 2014). Regarding the specificities of these results in the Nordic countries/territories, in the Faroe Islands and Greenland none of the programmes used them, while around half of the programmes in Finland, Sweden, and Denmark did not use them. On the other hand, in Norway all the service providers reported using risk assessment instruments, and the country risk assessment was done at the beginning, during and at the end of the treatment, with partner contact also being included as part of it. Finally, Norway had a perpetrator programme for ethnic minorities.

Findings from referrals and intake showed that there are very few court/justice system referrals compared to the European Union context, as well as few programmes that combined different referrals modalities. The inclusion of referrals from other agencies (particularly from the health care system) was reported as being a key challenge for the service providers, but the court/justice system referrals were not explicitly mentioned. In reference to the European Standards, specifically to offering a "coordinated response", the recommendation to accommodate different referral routes or paths of entry (including voluntary and court-mandated) has emerged as important.

On the other hand, motivation towards treatment emerges as an important factor in the Nordic countries/territories. In light of the Istanbul Convention and the European standards, it is important to note that motivation is an intake requirement in the Nordic countries/territories, but that this should be monitored during the programme in order to maximize programme retention and completion. Moreover, risk assessment and management should be included in all the programmes, and they should also include the partner's perspective.

Finally, very few programmes are sensitive to ethnic minorities, an aspect mentioned by many service providers as a significant challenge that they considered they still need to face.

\subsection{Methodology}

Around a third of the programmes reported not working according to any specific model (In Iceland and Norway all the service providers worked according to some model, while in Finland and the Faroe Islands, more than half of the programmes did not). The programmes reported a great variety of concepts that they worked in accordance with, with the most often mentioned being ATV and CBT; ATV was most common in Sweden, Iceland and Norway, while Finland and Denmark reported the greatest variety and less unified concepts of working. The approaches followed in treatment were CBT, psychodynamic, and psychoeducational. However, half of the service providers operated with a combination of models in the programme.

In the Europe context, the main models that programmes identified with were cognitive-behavioural and psycho-educational, which together represented two-thirds to three-quarters of the programmes. These results are similar to those in the Nordic countries/territories, although the psychodynamic and gender specific/feministic 
approaches were more relevant (more than 3 out of 4 , and more than half of the programmes respectively) in the Nordic countries/territories than in Europe.

Surprisingly, group work was not the most often followed intervention modality, but rather individual counselling, while couples counselling was also quite high (just Åland, Iceland and the Faroe Islands did not offer it, while more than $80 \%$ of programmes in Norway and Finland offered it). These results are different to what was found in the Europe context, in which the main modality of treatment was group work followed by individual work. Couple counselling was very rare in Europe (0.7\%) (Geldschläger, et al., 2014), while in the Nordic countries/territories, it was much more present (60\%).

Group work was mostly tackled by mixed team facilitators and in closed groups (although more than one third were open rolling groups), all sessions were offered on a weekly basis, for 1.5-2 hour sessions. Around half of the programmes reported that treatment lasts for " 14 to 26 weeks" and half again reported that it lasts " 27 to 52 weeks". Compared to the Europe results, the majority of the programmes reported the treatment to last from 14 to 52 weeks.

Individual counselling was offered with a male facilitator or a mixed team by more than half of the programmes, and a bit less than half of the programmes were conducted by a female facilitator. All the programs conducted individual counselling on a weekly basis, lasting for around 50 or 60 minutes; this treatment is most commonly offered without a pre-fixed number of sessions, but were offered on the basis of need. Just one in three programmes followed a specific concept for individual treatment, the most often mentioned being psychodynamic, CBT, ATV, and psychoeducational frames.

Couples counselling was mostly offered by a male or female team, weekly or on the basis of need, the session length ranging from 60 to 90 minutes, and the number of sessions being offered on the basis of need, or up to five sessions. More than half (68\%) did not work according to any concept of couples therapy, the most mentioned models being Sandra Stith and Justine van Lawick, IMAGO, and EFT.

Most of the programmes received more than 50 perpetrators in the previous year (all of the programmes in 5 out of the 7 countries/territories). The approximate number of perpetrators attending during the last year in Finland was up to 1,200 perpetrators across all the service providers (200 for the programmes located in the cities); Denmark had one service provider with 482 perpetrators attending, Norway had ATV services with around 880 perpetrators attending in total (around 80 per programme) and the SBM programme had around 90 perpetrators attending. In about half of the programmes, 50 to $75 \%$ of perpetrators completed the programme, therefore the attrition rate was about $50 \%$ to $25 \%$ of the attendants. Finland, Sweden, Denmark and the Faroe Islands had at least one service provider with more than $75 \%$ of perpetrators that completed the programme.

These results indicate that work still needs to be done to reach the European standards, especially the one referred to as "co-ordinated response", in which it is stated that the programmes should be delivered over a minimum of two years, with half of the programmes being offered remaining shorter than this recommendation. The lack of funding mentioned above was brought forward as an important challenge 
for the service providers, in terms of length and quality of the treatment (long-term planning and improvement of the programmes).

On the other hand, the recommendation to "work from a gender perspective" seems to be quite successful in the Nordic countries/territories compared to the Europe results. Nevertheless, half of the programmes did not yet apply this perspective. Moreover, around one third reported not working according to any specific model, reporting a great variety of concepts. This gives an overview of the great variety in current treatments available.

Finally, in terms of attrition rates, as proposed by Adams (2003), they can be considered as lying in the common range (from $25 \%$ to $65 \%$ ), while recommendations according to European standards measures should be taken into account to maximize completion rates (i.e. constant monitoring of perpetrators" motivation to complete treatment).

\subsection{Content of the work}

The most often mentioned main goals of the programmes were: "ending violence", "taking responsibility", "ensuring safety" (and well-being of victims). Some other aspects that were also mentioned included developing the perpetrator's "emotional self-regulation and communication skills", "understanding of violent acts and psychological causes", in addition to developing "parenting skills" and reducing "damage for victims".

Just one out of four programmes followed a manual or written curriculum in the treatment. However, despite this, the main approaches and goals for treatment seem to largely overlap among the programmes.

Regarding the main elements of work, more than $95 \%$ of the programmes reported the main elements as "accountability / responsibility for the violent behaviour of the perpetrators", "work on the effects of domestic violence on the victim and increase the perpetrators" empathy for the victim", and working on the "fathering and the effects of domestic violence on children". Most of the elements proposed in the questionnaire seemed to be important for the programmes, since even the least mentioned dimension "alcohol / drugs and violence" was indicated by nearly half of the programmes.

The results of the main elements of the work indicate that programmes in the Nordic countries/territories work in line with the main goals referred to in the Istanbul Convention and according to European standards: ensuring safety, holding perpetrators accountable, including the perspective of children (parenting skills), and helping perpetrators understand the impacts and consequences of violence.

\subsection{Partner Contact}


Almost one in five programmes (19\%) reported not contacting the (ex-) partner. In Norway, Iceland, Åland, and Greenland all the service providers reported not contacting the partner. The programmes who contacted the partner mostly contacted the current partner and ex-partner, with just 17\% contacting a new partner (as a potential victim) (mainly in Denmark, Finland, and Sweden). The (ex-) partner was mostly contacted at the beginning of the programme, and about half of the programmes contacted him/her in the course of work and/or at the end of it (all of Norway's service providers contacted the partner at the beginning, in the course of the programme, and at the end, while in Finland and Denmark, this happened in some programmes). More than $70 \%$ of the programmes reported that the purpose of contact with the (ex-) partner was: "to share information about specific victim services (e.g. victim's support services, shelters, services for refugees or migrants, counselling services for victims etc.)", "to share information about the programme and its content", and "to know about the partner experience of violence (their view on violent acts)". Surprisingly, just about a third of programmes reported contacting the partner to inform him/her about legal options, such as barring or protection orders or about specific working methods (e.g. time out) (Sweden and Norway). In Norway, the programmes reported sharing the most variety of information, followed by Sweden. Sharing information about the limitations of the programme took place in some programmes in Iceland, Sweden, and Norway. Most of the programmes $(83 \%)$ informed the partner in crisis situations, though some programmes reporting not contacting the partner in this circumstance.

Services for the partner were not offered in about $10 \%$ of the programmes (in Denmark and Norway all the programmes provided support services for the partner organised by their organization, whereas in Finland all the programmes reported support provided either by their organisations or by a partner organization). The programmes that did offer support offered mainly individual support (95\%), risk assessment and safety planning (80\%), and group work (71\%). However, a third of the programmes offered proactive contacts (contacts initiated by the support service) (present in Finland, Denmark, and Sweden). Regular support for the partner/ex-partner during participation in the programme was reported in Finland (around half of programmes), Denmark (50\%) and Sweden (about a third). As a safety measure for the programmes that offer services for the partner organised by their organization, they offered separate support persons for the perpetrator and victim (91.7\%), however, a third avoided contact between the perpetrator and victim as a safety measure.

Very few programmes (8.7\%) reported having no coordination with the victim support services (in Finland and Denmark one service provider and in Sweden two service providers did not coordinate with victim support services, while in Norway all the programmes coordinated with victim support services). Coordination was mostly done through joint planning and decision-making, although nearly half of the programmes that coordinated with victim support services do not have this joint planning. Just a third exchanged information about the case if necessary, and less than a third did this regularly. Half of the programmes exchanged information with the victim support services about high-risk situations, and a third reported not exchanging any kind of information with it. 
Comparing these results with those obtained in the European study, it was found that more programmes in Europe (almost a third) did not include a support service for the (ex-) partner. Moreover, in Europe overall, over a third of the programmes do not contact the (ex-) partners of their clients, while in the Nordic countries/territories more programmes do contact him/her. Of those programmes who do contact the (ex-) partner, in the Europe context overall half of them contacted the new partners as potential victims. However, in the case of the Nordic countries/territories, this is much less common, at about one in six (17\%).

According to the Istanbul Convention and the European standards the partner should be contacted and services should be offered to him/her, and so the results here show there is still room for improvement. According to the European Standards (section on "safety, security, and human dignity") programmes should offer (ex-) partners both group and individual support. Some programmes still do not offer services to the partner. More proactive contact should be emphasized. In the same section of the European Standards, it is stated that programmes should ensure that the (ex-) partner is informed about the goals and content of the programmes, its limitations, and how thee partner can use his/her attendance to manipulate or control him/her. However, about a third of programmes in the Nordic countries/territories do not share information about the programme, and around half of the programmes do not share information about the specific work methods and limitations of the programmes. Moreover, some programmes still do not inform the (ex-) partner even in crisis situations. Finally, it is recommended that contact with the partner should also be done during treatment and at the end of it.

\subsection{Quality assurance}

The most common measure of quality assurance adopted by the programmes were weekly team sessions ( $80 \%)$ and the continuing education of staff ( $90 \%)$. This activity is documented through annual statistics, an activity report, or standardized social statistics. The level of documentation is slightly more in the Nordic countries/territories (around 75\%) than in Europe (around 65\%). Finland had one service provider that reported using a standardized questionnaire during the process, and Sweden reported one programme that used interviews with the partner/ex-partner at the end of the treatment.

About a third of the programmes still do not measure outcomes (in Sweden and Denmark, half of the programmes reported not measuring outcomes, while in contrast, all the service providers in Iceland, the Faroe Islands, Norway and Finland reported that they measured outcomes). Of those that did measure outcomes, nearly a third did not measure outcomes at the end of the programme, and around $60 \%$ measure outcomes at the follow-up (around 12 months after the programme). Only service providers in Iceland did not measure outcomes at any follow-up point. The main outcomes measured by service providers are "non-violence and/or decrease of violence $(94.59 \%) "$ ", the "improvement in client's quality of life $(83.78 \%)$ ", and the "improvement 
in client's communication skills and conflict resolution skills $(70.27 \%)^{\prime \prime}$. The items referring to the partner situation received less emphasis: "improvement in partner's feeling of safety $(67.57 \%)$ ", "improvement of partner's quality of life $(29.73 \%)$ ", and "improvement in other aspects of the relationship (e.g. communication) (10.81\%)". The Faroe Island did not take into account any measure regarding the partner, while more than $50 \%$ of programmes in Finland, Norway, Denmark, and Iceland used the partners" information as an outcome. Moreover, in Sweden, one programme reported measuring the improvement in the children's feelings of safety.

The most often used instruments to measure outcomes were the client's selfassessment either by interview (78.95\%), or by questionnaire $(81.58 \%)$. Measures relating to the partner had some relevance, with the partner's assessment made either by interview $(47.37 \%)$, or by questionnaire or inventory (44.74\%). In general, measures related to the partner (around $50 \%$ ) have more relevance that those of the facilitator (a third). The Faroe Islands and Greenland did not take into account measures related to the partner, though they were relevant in (at least $50 \%$ of the programmes) Iceland, Denmark, Norway; a third of programmes took them into account in Finland, while a single program in Sweden took them into account. Finally, no programmes reported using official reports (police, court etc.) as an outcome measure.

Nearly a third of the programmes had no internal evaluation of their work, while half did not have an external evaluation. The only countries/territories that had an external evaluation of their programmes were Iceland and Norway; some programmes in Finland were externally evaluated. This external evaluation was done through collaboration with a research project with the universities (the Faroe Islands and Greenland also reported having an external evaluation but they did not specify how was it done).

In the Nordic countries/territories, similar to the Europe context overall, $20 \%$ of the programmes did not measure the outcome of their work. Those who did measure outcomes used mainly information from their clients and less than half of them measured outcomes in regard to the (ex-) partners, with results being similar between the Europe context overall and Nordic countries/territories. Outcomes were measured mainly at the end of the programme, with $60 \%$ of outcomes measured at follow-up in both the Nordic and Europe studies (in Europe this was done mainly in the first six months, while in the Nordic countries/territories it was around 12 months). The main dimensions that the programmes measured as outcomes, were similar in both studies (the present study and the European study): a stop/decrease in violence, and an improvement in the client's communication skills. However, in the Europe context overall it was seen as important to measure "attitudes and beliefs that support violence", while in the Nordic region it was "improvement in the client's quality of life" and "the partner's feelings of safety". The quality of the clients" life and fathering was used as an outcome measure by between half and two-thirds of the programmes in the Europe context study. In the Europe context study, the method the programmes used to measure outcomes were "reviewing their notes", while in the Nordic countries/territories this option was not used as much (15\%), with questionnaires used 
more to measure outcomes in the Nordic countries/territories than in the Europe context overall.

Based on the Istanbul Convention and the European standards, in evaluating the programmes, measures related to the partner should be more relevant and official reports should also be included as measures so as to triangulate data, together with the client's self-reports. Moreover, change should be measured individually and qualitatively, analysing variables that can be affected: for example, perceived severity, level of responsibility, etc. Finally, outcomes should be measured at the follow-up at least after 6 months, this appears to be done in the Nordic countries/territories.

In connecting these results with those on intake requirements, it would be useful to measure the participant's motivation during and after the programmes as an outcome measure. Moreover, the qualitative measure of outcome could also be based on the intake requirements of each programme. Programmes could make statements about the main characteristics of their clients based on specific behavioural and psychological aspects, which might be important when studying differences between participants and drop-outs and in studying different programmes.

Another of the key challenges mentioned by the programmes was training and education for developing post-treatment relapse pathways. This is also especially relevant as regards the Istanbul Convention, which encourages taking all the necessary legislative or other measures to support programmes aimed at preventing perpetrators from re-offending.

Finally, it is important to remark that in the European results, there was a bias among the main predictors of change as reported by the programmes and in how they measured outcomes afterwards. This resulted in different outcomes measured than what the service providers would consider to be the best predictors of change. In the case of the Nordic countries/territories, the main goals of their work (ending violent behaviour, taking responsibility, safety, and understanding their violent acts and communication skills) seem to be quite in line with the dimensions that they use to measure outcomes (communication skills, stopping violence, and partner safety). However, some aspects are not included in the outcome measurement, such as responsibility/accountability, safety (including partner's and child perspective) and understanding their violent acts. Therefore, these important aspects do not play an important role in outcomes measurement.

\subsection{Final thoughts and recommendations}

This sections looks at the basic questions of how services are provided in the Nordic countries/territories, what are the main treatment methodologies, how is safety guaranteed, and how are outcomes measured. A comparison with European data is also made. Finally, a comparison of these results with the minimum standards and European recommendations in light of the Istanbul Convention is carried out, together with a presentation of some best practice reported in some Nordic countries/territories. We 
believe that by including an example of best practice it might help Nordic countries/territories in cooperating and integrating work that is already being done.

\subsection{1 a) Characteristics of the service providers}

Regarding the geographical distribution of the services, $84 \%$ are located in urban areas, which should be taken into account given the extensive rural areas in some Nordic countries/territories. Funding of the programmes is mainly governmental, regional or municipal and it is mixed between permanent (in Norway, Sweden, and Iceland) and project-based funds (Denmark, Faroe Islands, and Greenland). Finland is a special case, with permanent funding coming from the Slot Machine Association and thus depending on its regulations. Therefore, although permanent and long-term funding is not very common in the Nordic countries/territories, funding is usually allocated on a yearly or 2-3-year basis. This might provoke difficulties in long-term planning and has been noted as a key challenge within different Nordic countries/territories (i.e. Sweden, Finland, Denmark, Faroe Islands, Greenland). This need for long-term planning/funding might be related to the fact that around a third of service provider staff work part-time. The staff is mostly composed of psychologists, although Finland has more psychotherapists and Sweden more social workers. The most common path of entry is the self-referred and those referred by other institutions, while very few are referred by the court/justice system.

Comparison with Europe context:

- In the Europe context there are more court-mandated clients and more programmes with various types of referrals.

\subsection{2 $\quad$ b) Main treatment methodologies followed}

The main services offered by the programmes are for male, female, and same sex perpetrators, as well as female and male victims of violence. A few services for child witnesses of violence are offered. Individual and group work are the treatment modalities most commonly offered, followed by couples work, which is also very common.

Despite the staff professionalization, there is a lack of clarity and consensus regarding working methodologies, and results show a great variety of approaches (such as CBT, psychodynamic, and psychoeducational, among others), both among countries/territories and within each country/territory. Moreover, around half of the programmes did not refer to having a gender/feministic approach. This diversity of approaches and models might reflect the need for specific staff training on the gender aspect of violence and its causes and consequences.

Comparison with Europe context:

- In the Europe region, couples counselling was very rare. Similarly, there is no standardized concept or method of working, and a gender specific/feministic 
approach is less relevant than in the Nordic countries/territories. Services for child witnesses of violence were less often offered in the Europe.

\subsection{3 c) Procedures followed to guarantee safety}

Most of the programmes reported contacting the partner, mostly at the beginning of the treatment, and also in crisis situations. However, half of the programmes did not contact the partner during the treatment or at the end of it. Most of the programmes offered services for the partner. The partner should also be included in terms of cooperating with the women's services; however, around half of the programmes do not cooperate with them. Furthermore, only a few countries (Iceland, and Norway, and to a lesser extend Sweden) reported referrals from victim services. The most often mentioned collaborating institutions were social services, family services, and the police, while only a third collaborate with health services. Risk-assessment instruments are not used by $40 \%$ of the programmes.

Comparison with Europe context:

- Nordic programmes contact the (ex-) partner more often, and they also include a support service for the (ex-) partner more commonly. However, in the Europe context, more programmes were collaborating with women's counselling services, and with health services.

\subsection{4 d) Procedures followed to measure outcome}

Twenty per cent of the programmes do not measure the outcome of their work; of those that do, outcomes are measured mostly at the end of the treatment $(60 \%$ measure outcomes at the follow-up). External evaluation of the programme is present in only half of the programmes. Some of the main goals of the work are not included in the outcomes measurement, such as responsibility/accountability and perpetrators" understanding of their violent acts, while others are not systematically measured, such as safety (from the partner's and child perspective).

In general, measures relating to the partner have more relevance than the those relating to the facilitator, and less than those relating to the client. No programme reported using the official reports (police, court etc.) as an outcome measure. The motivation towards the programme takes on a special relevance in the Nordic countries/territories as regards the intake requirements, and it can be screened during the intake phase (most of the programmes have a clearing phase). It typically takes the form of an initial interview, or a more complete process of individual counselling before the group. The completion rate for half of the programmes was from 50 to $75 \%$.

Comparison with Europe context:

- The number of programmes in the Europe context not measuring outcomes in general and at follow-up are at a similar level to the Nordic countries/territories. Outcomes relating to the partner are included slightly more often in Europe 
overall. A similar number of programmes have an intake procedure, although motivation was less important in the Europe context ( $4^{\text {th }}$ place vs $2^{\text {nd }}$ place). Outcome measures in the Nordic countries/territories were more standardized (through the use of questionnaires), whereas in the Europe context the method used to measure outcomes was to review the therapists" notes. In the European results, there is also a bias among the main predictors of change reported by the programmes and in how do they measure outcomes afterwards.

Taking into account the European standards and the Istanbul Convention and examples of best practices in the Nordic countries/territories, the final recommendations are:

Characteristics of the service providers:

- Services should be available free of charge and be equitably distributed across the geography of the country. Sweden is currently the only Nordic country that present some programme in rural areas.

- Long-term commitment in terms of financial resources is required. Most of the Nordic countries do not have long-term financial resources; currently the countries with more established and long-term funding are Sweden and Norway.

- Different referral routes or entry paths (including voluntary and court-mandated) should be accommodated. Sweden is the Nordic country that presents the highest amount of court/justice system referrals, and many varied referral paths, together with Norway.

- Provision of specialised service: staff should be specialized and programmes should focus on recognizing the gendered dynamics, impacts, and consequences of violence. Norway is the country with the most structured and homogeneous treatment approach, and where the gender approach is followed most, while the ATV model has a strong influence. Iceland and Sweden have many programmes strongly influenced by the ATV model.

Procedures to follow to guarantee safety:

- Partner should be included in the treatment process in different forms:

- Partner contact should be done at the begging of treatment, but also during the treatment and at the end of it.

- Cooperation with support service for victims (cooperation with women's counselling services and women's shelters) should be increased and emphasized in order to increase and prioritize the safety of the (ex-) partner.

- Risk assessment and management should include the partner's perspective.

- Programmes should offer (ex-) partners both group and individual support, and programmes should assure that the (ex-) partner is informed about the goals and content of the programmes, its limitations, and how the partner can use his/her attendance to manipulate or control the perpetrator. 
- Inform the (ex-) partner in crisis situations.

- Norway is only the country in which all the programmes contacted the partner at different moments during the treatment, that shared more varied information with him/her (i.e. limitations of the program) and that offered services to the partner, followed by Finland and Sweden.

- Risk assessment and management should be included in all the programmes. Norway and Iceland are the two Nordic countries that use risk assessment instruments in all the programmes.

Procedures to follow to measure outcome:

- Evaluation should triangulate data sources to measure outcomes/ success and include partner reports where possible, as well as including official data from the partner. Partner reports are especially relevant in Iceland, Denmark, and Norway, whereas Iceland, Norway, and Finland included an external evaluation of their programmes through collaboration with research projects from universities.

- Perpetrators' motivation to complete treatment should be constantly monitored (success must not be measured on programme completion rates or self-reported levels of violence alone). In Norway, all the service providers have motivation as an intake requirement, however, it is not clear from the questionnaire whether this motivation is also monitored during treatment.

- Take measures to maximize completion rates. Finland, Sweden, Denmark, and the Faroe Islands had high rating on programme completion (more than $75 \%$ of perpetrators completing some programmes).

\subsection{Limitations of the study and recommendations for future research}

Regarding the main limitations of the study it should be mentioned that not all the service providers identified responded to the questionnaire, and thus some important programmes may have been omitted from the study. However, the response rate for the questionnaire was $80 \%$ for all the Nordic countries/territories, so it was high compared to other results (Geldschläger et al., 2014).

Another important limitation of this study is that the data for this final report, were gathered from Country Reports, and thus there might have been some initial data elaboration and interpretation.

Moreover, it should also be noted that the questionnaire has been very useful in detecting differences and similarities among the Nordic countries/territories in terms of the minimum standards achieved, and it is an adequate tool for a first study of these 
characteristics. However, in following studies, it would be important to include more qualitative-based open questions, in order to obtain more information about how those minimum standards are established and achieved. Therefore, more differences in the quality of the programmes would be expected to emerge and more examples of best practices could be described and detailed.

Finally, another important limitation that should be taken into account is that percentages have been used for a very limited number of services. Furthermore, there are big differences across countries in terms of the number of programmes offered, therefore it can be problematic to compare results across countries just in terms of percentages. For this reason, when trying to analyse the results, it is important to take into account the frequencies, which have been included in order to overcome this limitation. 


\section{References}

Adams, P., Towns, A., \& Gavey, N. (1995). Dominance and entitlement: The rhetoric men use to discuss their violence towards women. Discourse \& Society, 6(3), 387-406.

https://doi.org/10.1177/0957926595006003006

Akoensi T.D., Koehler, J. A., Lösel, F. \& Humphreys, D. K. (2012). Domestic violence perpetrator programs in Europe, Part II: A systematic review of the state of evidence. International Journal of Offender Therapy and Comparative Criminology, 57(10), 1206-25).

https://doi.org/10.1177/0306624X12468110

Askeland, I.R., Evang, A., Heir, T. (2011). Association of Violence Against Partner and Former Victim Experiences: A Sample of Clients Voluntarily Attending Therapy. Journal of Interpersonal Violence, 26, 1095-1110. https://doi.org/10.1177/0886260510368152

Babcock, J. C., Green, C. E., \& Robie, C. (2004). Does batterers" treatment work? A metaanalytic review of domestic violence treatment. Clinical Psychology Review, 23,1023-1053. https://doi.org/10.1016/j.cpr.2002.07.001

Breiding, M., Basile, K. C., Smith, S. G., Black, M. C., Mahendra, R. (2015). Intimate partner violence surveillance uniform definitions and recommended data elements, Version 2.o. Atlanta (GA): National Center for Injury Prevention and Control, Centers for Disease Control and Prevention. Retrieved at:

http://www.cdc.gov/violenceprevention/pdf/ipv/intimatepartnerviolence.pdf

Council of Europe. (2016). Chart of signatures and ratifications of Treaty 210 Council of Europe Convention on preventing and combating violence against women and domestic violence. Retrieved at: http://www.coe.int/en/web/conventions/full-list//conventions/treaty/210/signatures

Council of Europe. (2011). Explanatory Report to the Council of Europe Convention on preventing and combating violence against women and domestic violence. Council of Europe Treaty Series - No. 210. Retrieved at:

https://rm.coe.int/CoERMPublicCommonSearchServices/DisplayDCTMContent?documentld= og00001680od383a

FRA (European Union Agency for Fundamental Rights). (2014). Violence against women: An EU-wide survey. Luxembourg: Publications Office of the European Union

Geldschläger, H., Ginés, O., Nax, D. \& Ponce, A. (2014). Outcome Measurement in European Perpetrator Programmes: A Survey (Working paper 1 from the Daphne III project "IMPACT: Evaluation of European Perpetrator Programmes". Retrieved at: http://www.work-withperpetrators.eu/fileadmin/WWP_Network/redakteure/IMPACT/Daphne_IIIIImpact__Working_paper_1_-_Outcome_Measurement_in_European_Perpetrator_Programmes_A_Survey.pdf

Gondolf, E. W. (2003). Program completion in specialized batterer counseling for African American men: An experimental clinical trial. Paper presented at the International Research Conference on Family Violence, Portsmouth, NH. Retrieved at: https://www.ncjrs.gov/pdffiles1/nij/201943.pdf

Gracia, E. \& Merlo, J. (2016). Intimate partner violence against women and the Nordic paradox. Social Science \& Medicine, 157, 27-30. doi: 10.1016/j.socscimed.2016.03.040. https://doi.org/10.1016/j.socscimed.2016.03.040

Hester, M. \& Lilley, S. (2014). Domestic and sexual violence perpetrator programmes: article 16 of the Istanbul convention. A collection of papers on the Council of Europe Convention on preventing and combating violence against women and domestic violence. Strasbourg: Directorate General of Human Rights and Legal Affairs, Council of Europe. Retrieved at: 
https://rm.coe.int/CoERMPublicCommonSearchServices/DisplayDCTMContent?documentld= $090000168046 \mathrm{e} 1 \mathrm{f} 2$

Kelly, L. \& Chair, R. (2008). Combating violence against women: minimum standards for support services. Strasbourg: Directorate General of Human Rights and Legal Affairs, Council of Europe. Retrieved at:

http://www.coe.int/t/dg2/equality/domesticviolencecampaign/Source/EG-VAWCONF(2007)Study\%2orev.en.pdf

Kelly, L., \& Westmarland, N. (2015). Domestic violence perpetrator programmes: Steps towards change. Project Mirabel final report. London and Durham: London Metropolitan University and Durham University. Retrieved at:

https://www.dur.ac.uk/resources/criva/ProjectMirabalfinalreport.pdf

Stover, C.S., Meadows, A. L. \& Kaufman, J. (2009). Interventions for intimate partner violence: Review and implications for evidence-based practice. Professional Psychology: Research and Practice, 40(3), 223-233. Doi: http://dx.doi.org/10.1037/a0012718

Wathen, C. N. \& MacMillan, H.L. (2003). Interventions for violence against women: scientific review. Scientific Review and Clinical Applications, 289(5):589-600.

https://doi.org/10.1001/jama.289.5.589 


\title{
Yhteenveto
}

\author{
Nu Räcker Det - Katsaus parisuhdeväkivallan tekijöiden kanssa \\ tehtävään työhön eri Pohjoismaissa
}

Nu Räcker Det on Pohjoismaisen ministerineuvoston rahoittama hanke, jonka tavoitteena oli selvittää, mitä eri toimintamalleja eri Pohjoismaissa (ml. Ahvenanmaa, Grönlanti ja Färsaaret) on käytössä parisuhdeväkivallan tekijöiden kanssa tehtävään työhön väkivaltaisen käytöksen kierteen katkaisemiseksi. Tiedonkeruu suoritettiin kyselyllä , joka lähetettiin tunnistetuille palvelujen tarjoajille joka maassa. Palvelun tarjoajia tavoitettiin yhteensä 68, ja vastausprosentti oli keskimäärin $80 \%$. Kartoitushankkeen tulokset pohjoismaisista väkivallan tekijäohjelmista julkaistaan loppuraportissa. Raportti julkaistaan vuoden 2017 alkupuolella Pohjoismaisen ministerineuvoston sivuilla (www.norden.org).

\section{Keskeiset tulokset}

\section{Palvelujen saatavuus}

Valtaosa väkivallan tekijöille suunnatuista palveluista (84 \%) oli saatavilla ainoastaan kaupunkiseuduilla. Poikkeuksen muodosti Ruotsi, jossa palveluja oli saatavilla jonkin verran myös maaseudulla. Palvelujen rahoitus oli varsin vakaata, mutta pysyvä tai pidempiaikainen rahoitus oli Pohjoismaissa poikkeuksellista. Tyypillisin oli kahdenkolmen vuoden rahoitussykli. Pohjoismaista pitkäaikaisin ja selvimmin julkisen sektorin varainen rahoitus oli Ruotsilla ja Norjalla. Kolmasosa palveluntarjoajien työntekijöistä oli osa-aikaisia. Yleisin ammattinimike oli psykologi. Tyypillisin palveluohjauksen muoto oli asiakkaan itsenäinen palveluihin hakeutuminen. Lisäksi varsin tavallista oli palveluohjaus toisesta palvelusta. Harva palveluohjaus tapahtui oikeuden toimesta. Eniten tuomioistuimen tekemiä palveluohjauksia tehtiin Ruotsissa, laajin valikoima palveluohjauksia oli Ruotsissa ja Norjassa.

\section{Saatavilla olevat palvelut ja hoidon muodot}

Valtaosa tarjolla olevista tekijäpalveluista ja väkivallan katkaisuohjelmista on suunnattu kaikille sukupulille väkivallan tekijöistä. Palveluja on tarjolla myös samaa sukupuolta oleville pariskunnille sekä kaikkia eri sukupuolia edustaville uhreille. Väkivaltaisen parisuhteen lapsille on vain vähän palveluita tarjolla missään Pohjoismaista. Keskeiset hoitomuodot ovat yksilöterapia ja ryhmäistunnot, lisäksi monilla on tarjota pariterapiaa. Hoitotyön taustalla oleva metodologia ei vastausten 
perusteella ollut yhtenäinen tai edes kovin selvä, vaan palveluntarjoajien vastaukset erosivat tässä suhteessa varsin paljon toisistaan sekä eri maiden välillä että maiden sisällä. Puolet vastaajista ilmoitti, etteivät he noudata sukupuolitietoista tai feminististä lähestymistapaa. Vastausten kirjavuus voi ilmentää henkilöstön koulutuksen tarvetta väkivallan sukupuolittuneisuudesta ilmiönä sekä sen seurauksista ja vaikutuksista uhrille. Kaikkein selvimmin rakentunut ja homogeenisin, sekä ilmiön sukupuolittuneisuuden parhaiten huomioiva palvelujärjestelmä oli Norjassa.

\section{Turvallisuuden varmistaminen}

Suurimmassa osassa ohjelmia väkivallan tekijän puolisoon otetaan yhteyttä sekä hoitoohjelman alussa sekä mahdollisissa kriisitilanteissa. Kuitenkin, jopa puolessa ohjelmista tekijän puolisoon ei otettu yhteyttä lainkaan enää ohjelman alkuvaiheen jälkeen. Suurin osa palveluntarjoajista tarjoaa palveluita myös väkivallan uhrille. Noin puolet ohjelmista ei tee yhteistyötä naisjärjestöjen kanssa ja vain harva tekee yhteistyötä terveyspalvelujen kanssa. Norjassa valittu linja erosi tästä selvästi, sillä se oli ainoa maa, jossa kaikki väkivallan tekijöitä hoitavat ohjelmat säännönmukaisesti pitivät yhteyttä tekijän puolisoon hoidon useissa eri vaiheissa. Lisäksi Norjassa jaettiin tekijän puolison kanssa huomattavasti enemmän ja erilaista informaatiota verrattuna muihin Pohjoismaihin ja tarjottiin säännöllisesti palveluja myös puolisolle. Saman suuntaisia vastauksia saatiin osin myös Ruotsista ja Suomesta. Riskinarviointityökaluja ei käytetty jopa $40 \%$ ohjelmista. Norjassa ja Islannissa riskinarviointityökalujen käyttö on muita maita yleisempää.

\section{Tulosten mittaaminen}

Lähes $20 \%$ ohjelmista ei mittaa hoidon tuloksia. Tyypillisimmin tuloksia mitataan hoidon loppuvaiheessa, ja $60 \%$ ohjelmista mittaa niitä seurannan yhteydessä. Ulkoista arviointia tehdään vain noin puolessa ohjelmista. Viranomaistietoa (poliisille tehdyt rikosilmoitukset perheväkivallasta, tuomioistuintapaustiedot) ei käytetä vaikuttavuuden arviointiin. Puolisolle tehtyjä haastatteluja käytetään hoidon lopputulosten mittaamisessa ja arvioimisessa erityisesti Islannissa, Tanskassa ja Norjassa. Hoidon aloittamisen kriteerinä käytetään Norjassa tekijän motivaation mittaamista, mutta vastauksista ei selviä, mitataanko motivaatiota myös hoidon lopussa ja vaikuttaako se hoidon tulosten arvioon. Islannissa, Norjassa ja Suomessa raportoitiin yksittäisiä ulkoisia arviointeja, yleensä yhteistyössä jonkin yliopiston tutkimusprojektien kanssa. Joitakin keskeisiä hoidon tavoitteita (tai tavoitteiden toteutumista) ei arvioida tulosten mittaamisen yhteydessä. Hoitojakson /ohjelman loppuun saattamisprosentit (completion rate) yli puolissa ohjelmista oli yli $50 \%$. Jotkin palvelun tuottajat Suomessa, Ruotsissa, Tanskassa ja Färsaarilla raportoivat jopa yli 75 $\%$ ohjelmiensa loppuun saattamisprosentteja. 


\section{Tulosten vertailua}

Kuten Pohjoismaissa, ei Euroopassakaan ole standardoitua metodia, jolla väkivallan tekijöiden kanssa tehtävää työtä toteutetaan, mutta sukupuolitietoinen/feministinen lähestymistapa on manner-Euroopassa vähemmän keskeinen. EU:n alueella tuomioistuinten palveluohjaukset tai tuomion suorittamisen osana edellytetyt hoitoohjelmat ovat tavallisempia kuin Pohjoismaissa. Manner-Euroopassa parisuhdeterapia on hyvin harvinaista. Parisuhdeväkivaltaa kotonaan todistaneille lapsille on tarjolla jopa vielä vähemmän palveluja kuin Pohjoismaissa. Lisäksi (ex-) puolisoon yhteyden ottaminen ohjelman/hoidon aikana on harvinaisempaa ja harvemmilla palveluntarjoajilla on palveluja myös (ex-) puolisolle tarjolla, kuin Pohjoismaissa. Sen sijaan manner-Euroopassa yhteistyö naisjärjestöjen sekä terveydenhuollon toimijoiden kanssa on Pohjoismaita tavallisempaa. Ohjelmien tulosten mittaaminen on yhtä yleistä, mutta puoliso on hieman useammin Euroopassa mukana tulosten mittaamisessa.

Suositukset Istanbulin sopimuksen valossa:

- Kuinka palveluja tulisi tarjota?

- Palveluja tulisi olla saatavilla maksuttomana ja yhdenvertaisesti eri osissa maata.

- Tarvitaan pitkän aikavälin sitoutumista palvelujen rahoitukseen.

- Palveluohjausta tulisi olla eri polkuja pitkin ( $\mathrm{ml}$. asiakas itse sekä oikeuden ohjaamana).

- Henkilöstön tulisi olla erityiskoulutuksen saanutta ja ohjelmien tulisi tunnistaa väkivallan sukupuolittunut dynamiikka, väkivallan vaikutukset ja sen seuraukset.

- Kuinka turvallisuus tulisi taata?

- Puoliso tulisi huomioida eri tavoin hoitoprosessissa:

- Puolisoon tulisi ottaa yhteyttä ohjelman alussa mutta myös sen aikana ja lopussa.

- Yhteistyötä uhripalvelujen (esim. naisjärjestöt ja turvakodit) tulisi lisätä ja uhrin turvallisuuden takaaminen priorisoida.

- Riskin arvioinnin ja hallinnan tulisi sisältää puolison näkemys.

- Ohjelmien tulisi tarjota (ex-) puolisoille sekä ryhmä- että yksilöllistä tukea ja ohjelmien tulisi varmistaa, että puoliso on tietoinen ohjelman sisällöstä ja tavoitteista, sekä mahdollisista rajoituksista jne.

- Kriisitilanteissa (ex-) puolisoa tulisi tiedottaa erikseen.

- Kaikissa ohjelmissa tulisi tehdä väkivallan riskin arviointia ja hallintaa. 
- Miten tuloksia tulisi mitata?

- Tulosten arvioinnissa tulisi yhdistää eri tietolähteitä, esimerkiksi puolison haastattelun muodossa tai viranomaistiedon avulla.

- Tekijän motivaatiota suorittaa ohjelma loppuun tulisi arvioida ohjelman aikana, eikä ohjelman onnistumista tulisi mitata vain ohjelman loppuun suorittamisen prosenttiosuuksilla tai itse raportoidulla väkivallan päättymisellä tai vähenemisellä.

- Ohjelmien loppuun saattamisen prosenttiosuuksia tulisi pyrkiä lisäämään.

Lisätietoja: Projektikoordinaattori Berta Vall, (berta.b.vall@jyu.fi). 


\section{Appendix}

\section{Appendix 1: NRD Questionnaire}

Table

NATIONAL INSTITUTE

\section{A. Basic Information}

A 1. Is your work with perpetrators of domestic violence part of a wider organization / institution / public services or NGO?

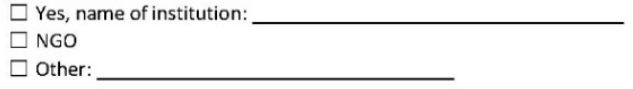

A 2. Does your work with perpetrators / your programme have a special name? $\square$ Work / programme is called:

$\square$ No specific name

A 3. Official contact information for the programme:

Name:
Street:
Town:- Pomber: Code:
Fax:
E-mail:
Tel.:
URL:
For request: Name of

A 4. Your work is located in a(n)

$$
\begin{aligned}
& \square \text { Urban area (e.g. Town etc.) } \\
& \square \text { Rural area } \\
& \square \text { Peri-urban area (small town) }
\end{aligned}
$$

A 5. When did your work / programme start? (Please, insert year) Work started in year: Country:

\section{B. Staff}

B 1. How many staff do you have?

(Facilitators means: all persons working with clients directly in any form)

(Administration means: all persons occupied with administration of the work with perpetrators) (Please add number of staff)

male:

male:

male:

male:

male:

male:

male:

male:

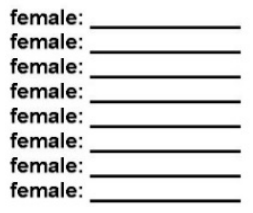


Table

NATIONAL INSTITUTE

FOR HEALTH AND WELFARE

C norden

B 2. Staff area of expertise for work with clients are

(please add number of staff with each qualification and the sum of weekly hours

of work for each category) (more than one option may be ticked)

Social workers:

Psychotherapists:

Psychologists:

Mental health workers:

Educators:

Ex-clients:

Others:

Expertise of „others":

hours in total:

hours in total:

hours in tota:

hours in total:

hours in total:

hours in tota:

hours in total:

\section{c. Eunding}

C 1. Please state the main sources of your

funding

(more than one option may be ticked)

$\square$ EU funds

$\square$ Governmental funds

$\square$ Regional funds

$\square$ Municipal funds

$\square$ Contribution by client

$\square$ Private Funds (donations, foundations etc.)

$\square$ Others:

C 2. Funding of work with perpetrators is

$\square$ Permanent

$\square$ Project based

$\square$ Case based

$\square$ Others:

$\square$ Length of the current funding (if not permanent):

C 3. What is the contribution by clients?

$\square$ No contribution by client

Euro (if other currency, please specify):

$\square$ Per session

$\square$ Monthly

$\square$ Whole measure

$\square$ Income dependent agreement with client

\section{4. Applying for funding}

How long are the funding periods?

How much time have you spent on applying for funding? (Average time in a

year/average part of working hours a year? 
Table

NATIONAL INSTITUTE

FOR HEALTH AND WELFARE

norden

\section{Cooperation and context}

D 1. Do you collaborate with other institutions / projects?

$$
\square \text { No }
$$

$\square$ Yes, with: (more than one option may be ticked)

$\square$ Police

$\square$ Criminal Court

$\square$ Civil Court

$\square$ Prosecutor

$\square$ Penal System

$\square$ Youth welfare office

$\square$ Alcohol treatment

$\square$ Substance abuse treatment

$\square$ Family services

$\square$ Women's shelter(s)

$\square$ Hospitals

$\square$ General practice doctors

$\square$ Emergency units

$\square$ Women's counselling services

$\square$ Social Services

$\square$ Other institution(s):

D 2. Is your work part of an inter-institutional alliance against domestic violence? (such as round tables or an intervention project against domestic violence etc.)

\section{$\square$ No}

$\square$ Yes, please choose:

$$
\begin{aligned}
& \square \text { National } \\
& \square \text { Regional } \\
& \square \text { Local }
\end{aligned}
$$

D 3. Does your institution provide services in the field of domestic violence?

$\square$ Male perpetrators

$\square$ Female perpetrators

$\square$ Same sex perpetrators

$\square$ Sexual offenders

$\square$ Child abuse offenders

$\square$ Perpetrators of violence in other relationships (e.g. crimes of honour)

$\square$ Other perpetrators:

$\square$ Child witnesses of violence

$\square$ Support for female victims of domestic violence

$\square$ Support for male victims of domestic violence

$\square$ Others: 
Table

NATIONAL INSTITUTE

FOR HEALTH AND WELFARE

Enordon

Referral and Intake

D 4. How do clients come to attend the programme?

(more than one option may be ticked)

$\square$ Court / Justice system referral

$\square$ Referred / recommended by other institutions.

What institutions/agencies:

$\square$ Social and welfare agencies

$\square$ Police

$\square$ Victim services

$\square$ Child protection services

$\square$ Alcohol and substance abuse treatment

$\square$ Other:

$\square$ Voluntarily self-referred

D 5. In which numerical proportion do the clients attend?

(Please chose approximate percentage)

court / justice referred

0\% $10 \% \quad 20 \% \quad 30 \% \quad 40 \% \quad 50 \% \quad 60 \% \quad 70 \% \quad 80 \%$

couldn't say

ther institutions referred

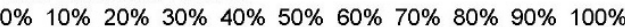

couldn't say

voluntarily referred

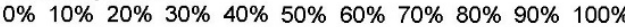

couldn't say

D 6. Do you have intake requirements for participants?

$\square$ No

$\square$ Yes, client has to: (more than one option may be ticked)

$\square$ Sign an agreement / contract as basis for programme participation

$\square$ Demonstrate a minimum of accountability for his abuse

$\square$ Demonstrate a minimum of motivation to participate in the measure

$\square$ Be able to cognitively follow the programme

$\square$ Have a good enough knowledge of language to follow the content of work

$\square$ Fulfil the facilitator's requirements for group work

$\square$ Agree to limited confidentiality (e.g. against partner, referringinstitutions)

$\square$ Give permission that facilitators can contact the partner

$\square$ Be alcohol and drug free during participation

$\square$ Be not affected by severe mental disorders

$\square$ Others: 
Table

NATIONAL INSTITUTE

D 7. Intake / clearing phase:

$\square$ No intake / clearing phase

$\square$ Only an initial interview

$\square$ Individual counselling phase before group work

$\square$ Others:

D 8. Do you have criteria for exclusion?

$\square$ No

$\square$ Yes, client can or will be excluded if he: (more than one option may beticked)

$\square$ Continues to be abusive toward his partner / ex-partner

$\square$ Is violent against group members or facilitators

$\square$ Breaks the agreement / contract

$\square$ Does not pay the fees

$\square$ Demonstrates a lack of participation / cooperation

$\square$ Is absent without permission from measure more than

$\square$ Is absent with valid excuse from measure more times

$\square$ Others:

D 9. Do you use risk-assessment instruments?

$\square$ No

$\square$ Yes

If yes, please specify the instruments you use:

D 10. Do you provide specific perpetrator programme(s) for migrants or ethnic minorities?

$\square$ Yes

$\square$ No

Methodology

D 11. Do you work according to some established concepts or a specific model of perpetrator treatment?

$\square$ No

$\square$ Yes, please specify:

D 12. Which of the following approaches correspond most closely to your work approach?

$\square$ Cognitive behavioural therapy/ (social) training

$\square$ Systemic approach / family therapy

$\square$ Psychodynamic approach

$\square$ Gender specific/feministic approach www.thl.fi

Terveyden ja hyvinvoinnin laitos • Institutet för hälsa och välfärd • National Institute for Health and Welfar

Mannerheimintie 166, Helsinki, Finland PL/PB/P.O. Box 30, FI-00271 Helsinki, puh/tel +358 295246000 
Table

NATIONAL INSTITUTE

FOR HEALTH AND WELFARE

norden

$\square$ Psychoeducational

$\square$ Constructivist and narrative

$\square$ Other approaches:

D 13. Work takes place as (more than one option may be

Group work: ticked)
Individual counselling (except intake/ clearing phase): YES
Couple counselling:
$\square$ Other counselling:

D 14. Group work takes place with:

$\square$ Not applicable (no group work) (please go to question D16.)

(more than one option may be ticked)

$\square$ One facilitator:

$$
\begin{aligned}
& \square \text { Male } \\
& \square \text { Female }
\end{aligned}
$$

$\square$ Team:

$$
\begin{aligned}
& \square \text { Male team } \\
& \square \text { Female team } \\
& \square \text { Mixed team }
\end{aligned}
$$

D 15. Framework of group work:

$\square$ Not applicable (no group work) (please go to question D16.)

$\square$ Open (rolling) groups

$\square$ Closed groups

$\square$ Both, please explain:

Frequency of group sessions:

$\square$ Weekly

$\square$ Twice weekly

$\square$ Fortnightly

$\square$ Other cycle:

Durations of sessions: single session: hours, altogether:

Duration of group work:

$$
\begin{aligned}
& \square \text { Up to } 13 \text { weeks } \\
& \square 14 \text { to } 26 \text { weeks } \\
& \square 27 \text { to } 52 \text { weeks } \\
& \square \text { Others: }
\end{aligned}
$$


Table

NATIONAL INSTITUTE

FOR HEALTH AND WELFARE

\section{norden}

Average number of group participants:

$$
\begin{aligned}
& \square 2 \text { - } 5 \text { participants } \\
& \square 6 \text { - } 10 \text { participants } \\
& \square \text { More than } 10 \text { participants }
\end{aligned}
$$

D 16. Individual counselling takes place with:

$\square$ Not applicable (no individual counselling after intake / clearing phase) (please go to question D18.)

(more than one option may be ticked)

$\square$ One facilitator:

$$
\begin{aligned}
& \square \text { Male } \\
& \square \text { Female }
\end{aligned}
$$

$\square$ Team:

$$
\begin{aligned}
& \square \text { Male team } \\
& \square \text { Female team } \\
& \square \text { Mixed team }
\end{aligned}
$$

D 17. Framework for individual

counselling: Frequency of

sessions:

$$
\begin{aligned}
& \square \text { Weekly } \\
& \square \text { Twice weekly } \\
& \square \text { Fortnightly } \\
& \square \text { Other cycle: }
\end{aligned}
$$

Duration of sessions: minutes

Duration of individual counselling:

$$
\begin{aligned}
& \square \text { Up to } 13 \text { weeks } \\
& \square 14 \text { to } 26 \text { weeks } \\
& \square 27 \text { to } 52 \text { weeks } \\
& \square \text { Others: }
\end{aligned}
$$

Do you work according to some established concepts or a specific model in individual counselling?

$\square$ No

$\square$ Yes, please specify:

D 18. Couples counselling takes place with:

$\square$ Not applicable (no couples counselling) (please go to question D20.)

(more than one option may be ticked)

$\square$ One facilitator:

$$
\square \text { Male }
$$


Table

NATIONAL INSTITUTE

FOR HEALTH AND WELFARE

norden

$\square$ Female

$\square$ Team:

$$
\begin{aligned}
& \square \text { Male team } \\
& \square \text { Female team } \\
& \square \text { Mixed team }
\end{aligned}
$$

D 19. Framework of couples counselling:

Frequency of sessions:

$$
\begin{aligned}
& \square \text { Weekly } \\
& \square \text { Twice weekly } \\
& \square \text { Fortnightly } \\
& \square \text { Other cycle: }
\end{aligned}
$$

Duration of sessions:

minutes

Duration of couples counselling:

$$
\begin{aligned}
& \square \text { Up to } 5 \text { sessions } \\
& \square 6 \text { up to } 10 \text { sessions } \\
& \square \text { More than } 10 \text { sessions } \\
& \square \text { Others: }
\end{aligned}
$$

Do you work according to some established concepts or a specific model of Couples counselling?

$\square$ No

$\square$ Yes, please specify:

D 20. How many perpetrators attended the programme in the last year? (after first contact and intake or clearing phase)

$$
\begin{aligned}
& \square \text { Less than } 25 \text { perpetrators } \\
& \square 25 \text { to } 50 \text { perpetrators } \\
& \square \text { More (approx.):__ perpetrators }
\end{aligned}
$$

D 21. How many of perpetrators completed the programme in the last year?

$$
\begin{aligned}
& \square \text { Less than } 50 \% \text { of attended perpetrators } \\
& \square 50 \text { to } 75 \% \text { of perpetrators } \\
& \square \text { Over } 75 \% \text { of perpetrators } \\
& \text { (Exact percentage if you know:__ }
\end{aligned}
$$


Table

NATIONAL INSTITUTE

FOR HEALTH AND WELFARE

norden

\section{E. Content of Work}

E 1. What are the three main goals of your work?

1.

2.

3.

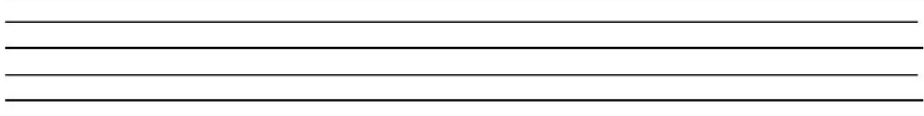

E 2. Do you use a written curriculum / manual?

$\square$ Yes (If yes, we would be pleased if you would send us a copy)

$\square$ No

E 3. Which of the following are essential / core elements of your work? (more than one option may be ticked]

$\square$ Gender roles and stereotypes (masculinity and femininity)

$\square$ Gender-specific power and control

$\square$ Attitudes and beliefs that support violence

$\square$ Accountability / responsibility for the violent behaviour

$\square$ Effects of domestic violence on the victim / empathy for the victim

$\square$ Fathering and effects of domestic violence on children

$\square$ Alcohol / drugs and violence

$\square$ High-risk situations (e. g. separation)

$\square$ Definition of violence / types of abuse (e. g. wheel of violence)

$\square$ Reconstruction of violent act(s)

$\square$ Confrontation with justification and minimizing strategies

$\square$ Time out

$\square$ Anger management

$\square$ Personal history of violence (biographical work)

$\square$ Egalitarian relationship

$\square$ Social skills (communication / conflict resolution)

$\square$ Self-awareness, self-reflection. and emotional expression

$\square$ Social relationships (friendship, social networks)

$\square$ Others: 
Table

NATIONAL INSTITUTE

FOR HEALTH AND WELFARE

norden

\section{F. Partner Contact}

F 1. Do you contact the partner / ex-partner of your clients?

(more than one option may be ticked)

$\square$ No (please go to question F5.)

$\square$ Current partner (who has suffered violence)

$\square$ Ex-partner (who has suffered violence)

$\square$ New partner (as a potential victim)

F 2. When do you contact the partner / ex-partner? (more than one option may be ticked)

$\square$ When client begins the programme

$\square$ In the course of work

$\square$ At the end of programme

$\square$ Others:

F 3. What is the purpose of the contact with the partner / ex-partner? (more than one option may be ticked)

$\square$ Information about the programme and its content

$\square$ Information about specific work methods (e.g. Time out)

$\square$ Information about limitation of the programme (no guarantee for non-violence)

$\square$ Information about legal options like barring or protection orders (if theyexist)

$\square$ Information about importance of safety measures

$\square$ Information about specific victim services (e.g. victim's support services, shelters,

services for refugees or migrants, counselling services for victims etc.)

$\square$ Partner experience of violence (their view on violent acts)

$\square$ Evaluation of the programme

$\square$ Others:

F 4. Is the partner / ex-partner informed in crisis situations and warned about risks?

$\square$ Yes
$\square$ No

Victim Support and Safety

F 5. Does your programme include a support service for the partner / ex-partner of your clients?

$\square$ No (please go to question G1.)

$\square$ Yes, provided by our organization

$\square$ Yes, provided by a partner organization (name of partner organization):

F 6. What does this support service offer? (more than one option may be ticked) 
Table

NATIONAL INSTITUTE

FOR HEALTH AND WELFARE

norden

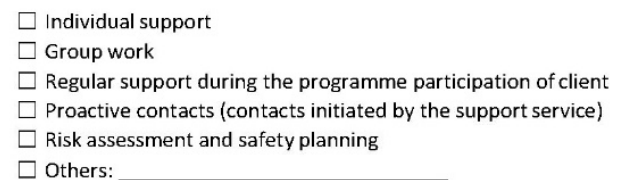

F 7. If victim support is provided by your organization, what safety measures are taken? (more than one option may be ticked)

$\square$ No unwanted contact between perpetrator and victim

$\square$ Separate support persons for perpetrator and victim

$\square$ Others:

F 8. How is the coordination with the victim support service organized? (more than one option may be ticked)

$\square$ Joint planning and decision-making

$\square$ Case-oriented exchange of information: regularly

$\square$ Case-oriented exchange of information: if required

$\square$ Others:

$\square$ No coordination

F 9. What information is exchanged with the support service?

(more than one option may be ticked)

$\square$ Repeated abuse by clien

$\square$ History of violence

$\square$ High-risk situation

$\square$ Others:

$\square$ No information is exchanged 
Table

NATIONAL INSTITUTE

FOR HEALTH AND WELFARE

\section{Unordon}

\section{G. Quality Assurance / Documentation / Evaluation}

G 1. Which of the following measures of quality assurance do you have? (more than one option may be ticked)

$\square$ Team Sessions

$\square$ Weekly

$\square$ Monthly

$\square$ Other frequency:

$\square$ Supervision, frequency:

$\square$ Continuing education of staff

$\square$ Others:

$\square$ None

G 2. What documentation and reporting system do you have? (more than one option may be ticked)

$\square$ Standardized documentation of social statistics data on clients

$\square$ Case-oriented, standardized documentation of work

$\square$ Case-oriented, non-standardized documentation of work (notes etc.)

$\square$ Annual activity report

$\square$ Annual statistics

$\square$ Others:

$\square$ None

G 3. Do you measure the outcome of your work?

$\square$ No (please go to the question G7)

$\square$ Yes, (more than one option may be ticked)

$\square$ When client finishes the programme

$\square$ At follow-up,__ months after finishing the programme

$\square$ At a second follow-up,__ months after finishing the programme

$\square$ Others:

G 4. What outcomes do you measure?

(more than one option may be ticked)

$\square$ Non-violence / decrease of violence

$\square$ Changes in attitudes and beliefs that support violence

$\square$ Improvement in client's communication skills and conflict resolutionskills

$\square$ Improvement in client's quality of life

$\square$ Improvement in other aspects of the relationship (e.g. communication)

$\square$ Improvement in partner's feeling of safety

$\square$ Improvement in partner's quality of life

$\square$ Others: 
Table

NATIONAL INSTITUTE

FOR HEALTH AND WELFARE

norden

G 5. What instruments do you use to measure outcomes?

(more than one option may be ticked)

$\square$ Client's self-assessment by interview

$\square$ Client's self-assessment by questionnaire

$\square$ Facilitator's assessment of client by psychological inventory

$\square$ Facilitator's assessment of client by other questionnaire

$\square$ Facilitator's assessment of client using internal documentation and minutes

$\square$ Partner's assessment by interview

$\square$ Partner's assessment by questionnaire or inventory

$\square$ Official reports (police, court etc.)

$\square$ Others:

G 6. If you use standardized instruments, please specify (abbreviations):

$\mathrm{G} 7$. Is there any evaluation of your

work?

(more than one option may be ticked)

$\square$ Internal evaluation

$\square$ External evaluation *

$\square$ Others:

$\square$ No evaluation

* If an external evaluation report is available, we would be pleased if you

would send us a copy

G 8. What are the challenges for your work in the future?

Thank you for completing the questionnaire!

This information may be published as results in a Nordic overview of the project. 
Table

NATIONAL INSTITUTE

FOR HEALTH AND WELFARE

\section{Unordon}

Appendix 2: Table summary main results and conclusions

Section A: Basic Information

\begin{tabular}{|c|c|c|c|c|c|}
\hline $\begin{array}{l}\text { Dimensions } \\
\text { of the } \\
\text { Questionna } \\
\text { ire }\end{array}$ & $\begin{array}{l}\text { Shortcomings and } \\
\text { advantages of Nordic } \\
\text { countries/territories }\end{array}$ & $\begin{array}{l}\text { Specificities in a } \\
\text { Nordic } \\
\text { country/territory }\end{array}$ & $\begin{array}{l}\text { Leading Nordic } \\
\text { country/territory }\end{array}$ & $\begin{array}{l}\text { Comparison } \\
\text { with Europe } \\
\text { (study by } \\
\text { Geldschläger } \\
\text { and } \\
\text { colleagues, } \\
2014 \text { ) }\end{array}$ & $\begin{array}{l}\text { Achievement of } \\
\text { European Standards } \\
\text { and Future } \\
\text { Recommendations }\end{array}$ \\
\hline \multirow[t]{3}{*}{$\begin{array}{l}\text { A. Basic } \\
\text { Information }\end{array}$} & $\begin{array}{l}\text { Half of the programmes } \\
\text { were part of a wider } \\
\text { organization and the } \\
\text { other half were part of } \\
\text { an NGO }\end{array}$ & $\begin{array}{l}\text { Part of an NGO: } \\
\text { Finland: all } \\
\text { programmes; } \\
\text { Norway most of the } \\
\text { programmes (91\%), } \\
\text { Denmark half of the } \\
\text { programmes. }\end{array}$ & & & \\
\hline & $\begin{array}{l}\text { Most of the } \\
\text { programmes were } \\
\text { located in an urban area }\end{array}$ & & $\begin{array}{l}\text { Just Sweden: one } \\
\text { programme in a } \\
\text { rural area, and } 3 \text { in } \\
\text { a peri-urban area. } \\
\text { Also Norway has } \\
\text { some/a few } \\
\text { programmes in } \\
\text { peri-urban area } \\
(\mathrm{n}=2)\end{array}$ & & $\begin{array}{l}\text { 'diversity and fair } \\
\text { access': services } \\
\text { should be equitably } \\
\text { distributed across } \\
\text { geography of the } \\
\text { country. }\end{array}$ \\
\hline & $\begin{array}{l}\text { More than half of the } \\
\text { programmes: 'very } \\
\text { old', while a quarter } \\
\text { can be considered as } \\
\text { 'new' }\end{array}$ & $\begin{array}{l}\text { Finland, Iceland, } \\
\text { and Norway report } \\
\text { mostly 'very old' } \\
\text { programmes. }\end{array}$ & $\begin{array}{l}\text { Sweden and } \\
\text { Denmark report the } \\
\text { most varied results } \\
\text { in all the categories }\end{array}$ & $\begin{array}{l}\text { in Europe } \\
\text { programmes } \\
\text { were more } \\
\text { evenly } \\
\text { distributed } \\
\text { over the four } \\
\text { categories } \\
\text { (with slight } \\
\text { over } \\
\text { representatio } \\
\text { nof the } \\
\text { young } \\
\text { programmes) }\end{array}$ & \\
\hline
\end{tabular}


Table

NATIONAL INSTITUTE

FOR HEALTH AND WELFARE

norden

Section B: Staff

\begin{tabular}{|c|c|c|c|c|c|}
\hline $\begin{array}{l}\text { Dimension } \\
\text { s of the } \\
\text { Questionna } \\
\text { ire }\end{array}$ & $\begin{array}{l}\text { Shortcomings and } \\
\text { advantages of Nordic } \\
\text { countries/territories }\end{array}$ & $\begin{array}{l}\text { Specificities in a } \\
\text { Nordic } \\
\text { country/territory }\end{array}$ & $\begin{array}{l}\text { Leading Nordic } \\
\text { country/territory }\end{array}$ & $\begin{array}{l}\text { Comparison } \\
\text { with Europe } \\
\text { (study of } \\
\text { Geldschläger } \\
\text { and } \\
\text { colleagues, } \\
\text { 2014) }\end{array}$ & $\begin{array}{l}\text { Accomplishment of } \\
\text { European Standards } \\
\text { and Future } \\
\text { Recommendations }\end{array}$ \\
\hline B. Staff & $\begin{array}{l}\text { Slightly more female } \\
\text { facilitators than male ones, } \\
\text { one third of the staff appear } \\
\text { to work part-time, and they } \\
\text { are mostly psychologists }\end{array}$ & $\begin{array}{l}\text { Finland (more than } \\
40 \%) \text {, Iceland } \\
(100 \%) \text {, Sweden } \\
\text { (more than } 30 \%) \\
\text { and Denmark (more } \\
\text { than } 20 \% \text { ) have } \\
\text { many part-time } \\
\text { workers. } \\
\text { Some countries do } \\
\text { not follow this } \\
\text { trend: Sweden has } \\
\text { more social workers } \\
\text { (n=11; } 42.3 \% \text { ), and } \\
\text { Finland more } \\
\text { psychotherapists } \\
\text { (n=25; 39.68\%). }\end{array}$ & $\begin{array}{l}\text { Norway all staff } \\
\text { working full-time }\end{array}$ & & $\begin{array}{l}\text { It is not elucidated by } \\
\text { the questionnaire if } \\
\text { staff are trained on } \\
\text { the nature of } \\
\text { violence, and it is } \\
\text { even less clear } \\
\text { whether they have the } \\
\text { cultural and linguistic } \\
\text { skills that will enable } \\
\text { them to work with a } \\
\text { wide diversity of men } \\
\text { attending such } \\
\text { programmes. }\end{array}$ \\
\hline
\end{tabular}


Table

NATIONAL INSTITUTE

FOR HEALTH AND WELFARE

Q norden

Section C: Funding

\begin{tabular}{|l|l|l|l|l|l|}
\hline $\begin{array}{l}\text { Dimension } \\
\text { sof the } \\
\text { Questionna } \\
\text { ire }\end{array}$ & $\begin{array}{l}\text { Shortcomings and } \\
\text { advantages of Nordic } \\
\text { countries/territories }\end{array}$ & $\begin{array}{l}\text { Specificities in a } \\
\text { Nordic } \\
\text { country/territory }\end{array}$ & $\begin{array}{l}\text { Leading Nordic } \\
\text { country/territory }\end{array}$ & $\begin{array}{l}\text { Comparison } \\
\text { with Europe } \\
\text { (study of } \\
\text { Geldschläger } \\
\text { and } \\
\text { colleagues, } \\
\text { 2014) }\end{array}$ & $\begin{array}{l}\text { Accomplishment of } \\
\text { European Standards } \\
\text { and Future } \\
\text { Recommendations }\end{array}$ \\
\hline C. Funding & $\begin{array}{l}\text { Very little European } \\
\text { funding. Typical funding is } \\
\text { municipal and } \\
\text { governmental. } \\
\text { Mostly permanent. However } \\
\text { most of it was reviewed on a } \\
\text { yearly or two-year basis. }\end{array}$ & $\begin{array}{l}\text { Only Faroe Islands } \\
\text { and Greenland } \\
\text { reported project- } \\
\text { based funding, and } \\
\text { Denmark reported } \\
\text { more project } \\
\text { funding (n=3; } \\
\text { than permanent } \\
\text { funding (n=1; } \\
\text { 25\%). Indeed, for } \\
\text { two services in } \\
\text { Denmark, the } \\
\text { funding ended } \\
\text { October 2016 and } \\
\text { they probably had } \\
\text { to close (ATV } \\
\text { services) }\end{array}$ & $\begin{array}{l}\text { Aland is the only } \\
\text { territory that has } \\
\text { EU funding }\end{array}$ & & $\begin{array}{l}\text { 'coordinated } \\
\text { response' is required } \\
\text { long-term } \\
\text { commitment in terms } \\
\text { of financial resources }\end{array}$ \\
& $\begin{array}{l}\text { Concentrated in } \\
\text { Norway and Iceland } \\
\text { (all of their } \\
\text { programmes). }\end{array}$ & & & \\
& $\begin{array}{l}\text { Client's contribution was } \\
\text { required in less than half of } \\
\text { the programs }\end{array}$ & & & & \\
\hline
\end{tabular}


Table

NATIONAL INSTITUTE

FOR HEALTH AND WELFARE

On nordan

Section D: Cooperation and Context: the program

\begin{tabular}{|c|c|c|c|c|c|}
\hline $\begin{array}{l}\text { Dimension } \\
\text { s of the } \\
\text { Questionna } \\
\text { ire }\end{array}$ & $\begin{array}{l}\text { Shortcomings and } \\
\text { advantages of Nordic } \\
\text { countries/territories }\end{array}$ & $\begin{array}{l}\text { Specificities in a } \\
\text { Nordic } \\
\text { country/territory }\end{array}$ & $\begin{array}{l}\text { Leading Nordic } \\
\text { country/territory }\end{array}$ & $\begin{array}{l}\text { Comparison } \\
\text { with Europe } \\
\text { (study by } \\
\text { Geldschläger } \\
\text { and } \\
\text { colleagues, } \\
\text { 2014) }\end{array}$ & $\begin{array}{l}\text { Accomplishment of } \\
\text { European Standards } \\
\text { and Future } \\
\text { Recommendations }\end{array}$ \\
\hline \multirow[t]{3}{*}{$\begin{array}{l}\text { D. } \\
\text { Cooperatio } \\
\text { n and } \\
\text { Context the } \\
\text { program. }\end{array}$} & $\begin{array}{l}\text { All the service providers } \\
\text { collaborate with other } \\
\text { institutions. } \\
\text { Collaboration with health } \\
\text { services (hospitals, and } \\
\text { general practice doctors), } \\
\text { judicial services (criminal } \\
\text { and civil court, prosecutor), } \\
\text { and women's services } \\
\text { (women's shelters, and } \\
\text { counselling services) are still } \\
\text { very low (around a third of } \\
\text { the programmes reported } \\
\text { collaborating with them, } \\
\text { with the exception of } \\
\text { women's shelters, which } \\
\text { was indicated by around two } \\
\text { thirds of the programmes } \\
\text { and the women's } \\
\text { counselling services, } \\
\text { indicated by around half of } \\
\text { programmes). }\end{array}$ & $\begin{array}{l}\text { Iceland, Denmark, } \\
\text { Faroe Islands and } \\
\text { Greenland no } \\
\text { cooperation with } \\
\text { women's } \\
\text { counselling } \\
\text { services. }\end{array}$ & $\begin{array}{l}\text { Norway, nearly all } \\
\text { services cooperate } \\
\text { with women's } \\
\text { counselling } \\
\text { services, while in } \\
\text { Finland and } \\
\text { Sweden it was } \\
\text { around half. } \\
\text { Sweden and } \\
\text { Norway cooperate } \\
\text { with judicial } \\
\text { services (Faroe } \\
\text { Islands and } \\
\text { Denmark just } \\
\text { Criminal Court) }\end{array}$ & $\begin{array}{l}\text { Collaboratio } \\
\mathrm{n} \text { with the } \\
\text { women's } \\
\text { counselling } \\
\text { services in } \\
\text { the EU there } \\
\text { were more } \\
\text { programmes } \\
\text { collaborating } \\
\text { with these } \\
\text { services (two } \\
\text { out of three } \\
\text { programmes) }\end{array}$ & $\begin{array}{l}\text { Programmes follow a } \\
\text { 'systems approach': } \\
\text { all the services } \\
\text { cooperate with other } \\
\text { institutions and } \\
\text { usually with more } \\
\text { than one. However, } \\
\text { cooperation with } \\
\text { women's services } \\
\text { should be increased } \\
\text { and emphasized in } \\
\text { order to increase and } \\
\text { prioritize the safety } \\
\text { of the (ex-) partner. }\end{array}$ \\
\hline & $\begin{array}{l}\text { Most of the programmes } \\
\text { (more than } 80 \% \text { ) reported } \\
\text { being part of an inter- } \\
\text { institutional alliance on } \\
\text { domestic violence }\end{array}$ & $\begin{array}{l}\text { Just Sweden, and } \\
\text { Denmark had } \\
\text { programmes that } \\
\text { were not part of an } \\
\text { inter-institutional } \\
\text { alliance }\end{array}$ & $\begin{array}{l}\text { All the service } \\
\text { providers were part } \\
\text { of an inter- } \\
\text { institutional } \\
\text { alliance against } \\
\text { domestic violence } \\
\text { (Finland, Iceland, } \\
\text { Faroe Islands and } \\
\text { Norway) }\end{array}$ & $\begin{array}{l}\text { In the EU } \\
\text { the number } \\
\text { of } \\
\text { programmes } \\
\text { that were } \\
\text { part of an } \\
\text { inter- } \\
\text { institutional } \\
\text { alliance was } \\
\text { slightly } \\
\text { lower }(75 \%)\end{array}$ & $\begin{array}{l}\text { Programmes follow a } \\
\text { 'systems approach': }\end{array}$ \\
\hline & $\begin{array}{l}\text { Most of the Nordic } \\
\text { countries/territories offer a } \\
\text { wide variety of services. } \\
\text { Nearly all the programmes } \\
\text { offered services for male } \\
\text { perpetrators, but many } \\
\text { offered also services for } \\
\text { female and same-sex } \\
\text { perpetrators and female and } \\
\text { male victims of violence } \\
\text { (around three out of four } \\
\text { programmes). Around half } \\
\text { of the programmes also } \\
\text { offered services for sexual }\end{array}$ & & $\begin{array}{l}\text { Services for child } \\
\text { witnesses of } \\
\text { violence were most } \\
\text { often offered in } \\
\text { Denmark ( } \mathrm{n}=3 \text {; } \\
75 \%) \text {, Sweden } \\
(\mathrm{n}=7 ; 41.2 \%) \text {, and } \\
\text { Greenland ( }=1 \text {; } \\
100 \%) \text {. }\end{array}$ & $\begin{array}{l}\text { European } \\
\text { level showed } \\
\text { that } 32.1 \% \\
\text { of the } \\
\text { programmes } \\
\text { also offered } \\
\text { interventions } \\
\text { for sex } \\
\text { offenders }\end{array}$ & $\begin{array}{l}\text { As stated in the } \\
\text { Istanbul Convention } \\
\text { programmes for } \\
\text { domestic violence } \\
\text { perpetrators and } \\
\text { sexual violence } \\
\text { perpetrators tend to } \\
\text { be administered } \\
\text { separately. However, } \\
\text { there are important } \\
\text { connections between } \\
\text { these types of } \\
\text { programmes, } \\
\text { consistent with the }\end{array}$ \\
\hline
\end{tabular}

www.thl.fi

Terveyden ja hyvinvoinnin laitos $\bullet$ Institutet för hälsa och välfärd $\bullet$ National Institute for Health and Welfar

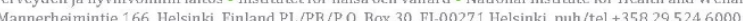


Table

NATIONAL INSTITUTE

FOR HEALTH AND WELFARE

Unorden

\begin{tabular}{|l|l|l|l|l|l|}
\hline & $\begin{array}{l}\text { offenders. } \\
\text { Services for child witnesses } \\
\text { of violence are less often } \\
\text { offered }(\mathrm{n}=21 ; 41.2 \%) .\end{array}$ & & & & $\begin{array}{l}\text { practice of working } \\
\text { across different forms } \\
\text { of violence against } \\
\text { women. }\end{array}$ \\
\hline
\end{tabular}


Table

NATIONAL INSTITUTE

FOR HEALTH AND WELFARE

\section{Enordon}

Section D: Cooperation and Context: referral and intake

\begin{tabular}{|c|c|c|c|c|c|}
\hline $\begin{array}{l}\text { Dimension } \\
\text { s of the } \\
\text { Questionna } \\
\text { ire }\end{array}$ & $\begin{array}{l}\text { Shortcomings and } \\
\text { advantages of Nordic } \\
\text { countries/territories }\end{array}$ & $\begin{array}{l}\text { Specificities in a } \\
\text { Nordic } \\
\text { country/territory }\end{array}$ & $\begin{array}{l}\text { Leading Nordic } \\
\text { country/territory }\end{array}$ & $\begin{array}{l}\text { Comparison } \\
\text { with Europe } \\
\text { (study by } \\
\text { Geldschläger } \\
\text { and } \\
\text { colleagues, } \\
\text { 2014) }\end{array}$ & $\begin{array}{l}\text { Accomplishment of } \\
\text { European Standards } \\
\text { and Future } \\
\text { Recommendations }\end{array}$ \\
\hline \multirow[t]{3}{*}{$\begin{array}{l}\text { D. } \\
\text { Cooperatio } \\
\mathrm{n} \text { and } \\
\text { Context } \\
\text { referral } \\
\text { and intake }\end{array}$} & $\begin{array}{l}\text { Most of perpetrators are self- } \\
\text { referred or referred by other } \\
\text { agencies (welfare agencies } \\
\text { and the police mostly), very } \\
\text { few are referred by the } \\
\text { court/justice system (just } \\
\text { three programmes) or by } \\
\text { victim services ( } n=21 \text {; } \\
8.7 \% \text { ). Indeed, most of the } \\
\text { programs do not have } \\
\text { referral from court/justice } \\
\text { system at all. }\end{array}$ & $\begin{array}{l}\text { Aland and } \\
\text { Greenland have just } \\
\text { voluntary self- } \\
\text { referrals }\end{array}$ & $\begin{array}{l}\text { just Finland }(\mathrm{n}=1 ; \\
7.1 \%), \text { Sweden } \\
(\mathrm{n}=3 ; 17.7 \%) \text {, and } \\
\text { Norway }(\mathrm{n}=1 \text {; } \\
8.3 \%) \text { reported } \\
\text { some referrals from } \\
\text { the court } \mathrm{justice} \\
\text { system. Just Iceland } \\
(\mathrm{n}=1 ; 100 \%) \text {, } \\
\mathrm{Sweden}(\mathrm{n}=9 \text {; } \\
52.9 \%) \text { and Norway } \\
(\mathrm{n}=12 ; 100) \\
\text { reported referrals } \\
\text { from victim } \\
\text { services. }\end{array}$ & $\begin{array}{l}\text { Results from } \\
\text { the EU } \\
\text { showed that } \\
\text { the majority } \\
\text { of } \\
\text { programmes } \\
\text { worked with } \\
\text { various kind } \\
\text { of referrals } \\
\text { (less court- } \\
\text { mandated } \\
\text { clients and } \\
\text { less } \\
\text { programmes } \\
\text { with various } \\
\text { types of } \\
\text { referrals in } \\
\text { Nordic } \\
\text { countries/terr } \\
\text { itories). }\end{array}$ & $\begin{array}{l}\text { 'coordinated } \\
\text { response': } \\
\text { accommodating } \\
\text { different referral } \\
\text { routes or entry paths } \\
\text { (including voluntary } \\
\text { and court-mandated) }\end{array}$ \\
\hline & $\begin{array}{l}\text { Just four programmes did } \\
\text { not have intake } \\
\text { requirements. The most } \\
\text { common intake requirements } \\
\text { (selected by more than half } \\
\text { of the programmes) were } \\
\text { 'being alcohol and drug } \\
\text { free', 'being motivated to } \\
\text { participate' and 'being able } \\
\text { to cognitively follow the } \\
\text { programme'. }\end{array}$ & $\begin{array}{l}\text { Three programmes } \\
\text { in Finland and one } \\
\text { in the Faroe Islands } \\
\text { did not have intake } \\
\text { requirements }\end{array}$ & & $\begin{array}{l}\text { In the EU } \\
\text { context, the } \\
\text { same amount } \\
\text { of } \\
\text { programmes } \\
\text { did not have } \\
\text { intake } \\
\text { requirements } \\
\text { The main } \\
\text { intake } \\
\text { requirements } \\
\text { were: 'being } \\
\text { alcohol and } \\
\text { drug free' } \\
\text { 'not having } \\
\text { mental } \\
\text { disorders' } \\
\text { and having } \\
\text { 'sufficient } \\
\text { language } \\
\text { skills'. }\end{array}$ & $\begin{array}{l}\text { Motivation towards } \\
\text { treatment emerges as } \\
\text { an important } \\
\text { emphasis in the } \\
\text { Nordic } \\
\text { countries/territories. } \\
\text { In light of the } \\
\text { Istanbul Convention } \\
\text { and European } \\
\text { Standards it is } \\
\text { important to note that } \\
\text { motivation being part } \\
\text { of intake } \\
\text { requirements is a } \\
\text { significant factor, but } \\
\text { this should also be } \\
\text { monitored during the } \\
\text { programme in order } \\
\text { to maximize } \\
\text { programme retention } \\
\text { and completion }\end{array}$ \\
\hline & $\begin{array}{l}\text { Intake procedure, still a few } \\
\text { programmes }(8 \%) \text { do not } \\
\text { undertake any clearing } \\
\text { phase, with around } 20 \% \text { just } \\
\text { undertaking an initial } \\
\text { interview, while more than }\end{array}$ & $\begin{array}{l}\text { Sweden and the } \\
\text { Faroe Islands had } \\
\text { some programmes } \\
\text { that did not have } \\
\text { any intake/clearing } \\
\text { phase. }\end{array}$ & $\begin{array}{l}\text { In Finland, and } \\
\text { Norway ( } \AA \text { land } \\
\text { too) all the } \\
\text { programmes } \\
\text { reported an } \\
\text { individual }\end{array}$ & $\begin{array}{l}\text { Similarly, in } \\
\text { the EU } \\
\text { context } 95 \% \\
\text { of the } \\
\text { programmes } \\
\text { had some }\end{array}$ & \\
\hline
\end{tabular}

www.thl.fi

Terveyden ja hyvinvoinnin laitos • Institutet för hälsa och välffärd • National Institute for Health and Welfare

Mannerheimintie 166. Helsinki. Finland PL/PB/P.O. Box 30, FL-00271 Helsinki, puh/tel + 358295246000 
Table

NATIONAL INSTITUTE

FOR HEALTH AND WELFARE

\section{norden}

\begin{tabular}{|c|c|c|c|c|}
\hline $\begin{array}{l}\text { half report an individual } \\
\text { counselling phase before the } \\
\text { group work starts. }\end{array}$ & & $\begin{array}{l}\text { counselling phase } \\
\text { before the group } \\
\text { work as a clearing } \\
\text { phase. }\end{array}$ & $\begin{array}{l}\text { intake } \\
\text { procedure. }\end{array}$ & \\
\hline $\begin{array}{l}\text { Many programmes (40\%) } \\
\text { still do not use any risk } \\
\text { assessment instruments }\end{array}$ & $\begin{array}{l}\text { In Finland, Sweden, } \\
\text { and Denmark, } \\
\text { around half of the } \\
\text { programmes do not } \\
\text { use risk-assessment } \\
\text { instruments (in the } \\
\text { Faroe Islands and } \\
\text { Greenland, none of } \\
\text { the programmes do) }\end{array}$ & $\begin{array}{l}\text { In Norway and } \\
\text { Iceland, all the } \\
\text { service providers } \\
\text { use risk-assessment } \\
\text { instruments. } \\
\text { Moreover, in } \\
\text { Norway, risk } \\
\text { assessment is done } \\
\text { at the beginning, } \\
\text { during, and at the } \\
\text { end of the } \\
\text { treatment. Partner } \\
\text { contact is part of } \\
\text { the risk assessment. }\end{array}$ & $\begin{array}{l}\text { Similar } \\
\text { results were } \\
\text { obtained in } \\
\text { the European } \\
\text { context }\end{array}$ & $\begin{array}{l}\text { Risk assessment and } \\
\text { management should } \\
\text { be included in all the } \\
\text { programmes, and } \\
\text { they should also } \\
\text { include the partner's } \\
\text { perspective. }\end{array}$ \\
\hline $\begin{array}{l}\text { Very few programmes for } \\
\text { ethnic minorities }\end{array}$ & & $\begin{array}{l}\text { Only Norway had a } \\
\text { perpetrator } \\
\text { programme for } \\
\text { ethnic minorities. }\end{array}$ & & $\begin{array}{l}\text { very few programmes } \\
\text { are sensitive to ethnic } \\
\text { minorities }\end{array}$ \\
\hline
\end{tabular}


Table

NATIONAL INSTITUTE

FOR HEALTH AND WELFARE

\section{E nordon}

Section D: Cooperation and Context: Methodology

\begin{tabular}{|c|c|c|c|c|c|}
\hline $\begin{array}{l}\text { Dimension } \\
\text { s of the } \\
\text { Questionna } \\
\text { ire }\end{array}$ & $\begin{array}{l}\text { Shortcomings and } \\
\text { advantages of Nordic } \\
\text { countries/territories }\end{array}$ & $\begin{array}{l}\text { Specificities in a } \\
\text { Nordic } \\
\text { country/territory }\end{array}$ & $\begin{array}{l}\text { Leading Nordic } \\
\text { country/territory }\end{array}$ & $\begin{array}{l}\text { Comparison } \\
\text { with Europe } \\
\text { (study by } \\
\text { Geldschläger } \\
\text { and } \\
\text { colleagues, } \\
\text { 2014) }\end{array}$ & $\begin{array}{l}\text { Accomplishment of } \\
\text { European Standards } \\
\text { and Future } \\
\text { Recommendations }\end{array}$ \\
\hline \multirow[t]{3}{*}{$\begin{array}{l}\text { D. } \\
\text { Cooperatio } \\
\text { n and } \\
\text { Context } \\
\text { methodolo } \\
\text { gy }\end{array}$} & $\begin{array}{l}\text { Around one third of the } \\
\text { programmes reported not } \\
\text { working according to any } \\
\text { specific model. } \\
\text { The most common models } \\
\text { followed were ATV } \\
\text { (Iceland, Norway, and } \\
\text { Sweden ( } 77 \% \text { ), and CBT } \\
\text { (Denmark, Sweden) and } \\
\text { integrated method, } \\
\text { psychodynamic, dialogic } \\
\text { (Finland), Psychodynamic, } \\
\text { constructivism, EFT, } \\
\text { systemic (Denmark) }\end{array}$ & $\begin{array}{l}\text { More than half of } \\
\text { the programmes in } \\
\text { Finland that did not } \\
\text { use a specific } \\
\text { model, and none in } \\
\text { the Faroe Islands } \\
(n=1)\end{array}$ & $\begin{array}{l}\text { In Iceland and } \\
\text { Norway all the } \\
\text { service providers } \\
\text { worked according } \\
\text { to a model. ATV } \\
\text { was most common } \\
\text { model in Sweden, } \\
\text { Iceland and } \\
\text { Norway. } \\
\text { Finland and } \\
\text { Denmark had the } \\
\text { most varied } \\
\text { concepts for the } \\
\text { work, less unified. }\end{array}$ & & \\
\hline & $\begin{array}{l}\text { Approaches followed in } \\
\text { treatment: CBT, } \\
\text { Psychodynamic, } \\
\text { Psychoeducational, and } \\
\text { Gender/Feministic }\end{array}$ & & & $\begin{array}{l}\text { Similarly in } \\
\text { the EU, the } \\
\text { main models } \\
\text { were: CBT } \\
\text { and } \\
\text { psychoeduca } \\
\text { tional. } \\
\text { Psychodyna } \\
\text { mic and } \\
\text { Gender } \\
\text { specific/femi } \\
\text { nistic } \\
\text { approaches } \\
\text { were more } \\
\text { relevant in } \\
\text { the Nordic } \\
\text { countriesiterr } \\
\text { itories than } \\
\text { in Europe. }\end{array}$ & $\begin{array}{l}\text { 'Working from a } \\
\text { gender perspective' } \\
\text { seems to be quite } \\
\text { prevalent in the } \\
\text { Nordic } \\
\text { countries/territories } \\
\text { compared to the EU, } \\
\text { however, only half of } \\
\text { the programmes } \\
\text { applied this } \\
\text { perspective. }\end{array}$ \\
\hline & $\begin{array}{l}\text { Surprisingly, group work } \\
\text { was not the most often } \\
\text { followed intervention } \\
\text { modality, which was rather } \\
\text { individual counselling, while } \\
\text { couples counselling was also } \\
\text { quite high. }\end{array}$ & $\begin{array}{l}\text { Aland, Iceland and } \\
\text { Faroe Islands do } \\
\text { not offer couples } \\
\text { treatment }\end{array}$ & $\begin{array}{l}\text { Couples } \\
\text { counselling is } \\
\text { especially present } \\
\text { in Norway ( } \mathrm{n}=11 ; \\
91.7 \% \text { ) and Finland } \\
\mathrm{n}=12 ; 85.7 \%) \text {. }\end{array}$ & $\begin{array}{l}\text { The main } \\
\text { modality of } \\
\text { treatment } \\
\text { was group } \\
\text { work } \\
\text { followed by } \\
\text { individual } \\
\text { work. } \\
\text { Couples } \\
\text { counselling } \\
\text { was very } \\
\text { rare in } \\
\text { Europe }\end{array}$ & $\begin{array}{l}\text { 'co-ordinated } \\
\text { response' in which it } \\
\text { is stated that the } \\
\text { programmes should } \\
\text { be delivered over a } \\
\text { minimum of two } \\
\text { years. Nevertheless, } \\
\text { half of the } \\
\text { programmes offered } \\
\text { are shorter than this } \\
\text { recommendation. The } \\
\text { lack of funding } \\
\text { mentioned above was }\end{array}$ \\
\hline
\end{tabular}


Table

NATIONAL INSTITUTE

FOR HEALTH AND WELFARE

\section{norden}

\begin{tabular}{|c|c|c|c|}
\hline & & $\begin{array}{l}(0.7 \%) \\
\text { whereas in } \\
\text { the Nordic } \\
\text { countries/terr } \\
\text { itories it was } \\
\text { much more } \\
\text { common } \\
(60 \%) \text {. }\end{array}$ & $\begin{array}{l}\text { mentioned as an } \\
\text { important challenge } \\
\text { for the participants, in } \\
\text { terms of length and } \\
\text { quality of the } \\
\text { treatment (long-term } \\
\text { planning and } \\
\text { improvement of the } \\
\text { programmes). }\end{array}$ \\
\hline $\begin{array}{l}\text { Most of the programmes } \\
\text { received more than } 50 \\
\text { perpetrators in the last year } \\
\text { (all of the programmes in } 5 \\
\text { out of } 7 \text { countries). }\end{array}$ & $\begin{array}{l}\text { Norway }(100 \%) \text {, } \\
\text { Iceland }(100 \%), \\
\text { Finland }(35.7 \%) \\
\text { and Denmark } \\
(25 \%) \text { had service } \\
\text { providers attending } \\
\text { more than } 50 \\
\text { perpetrators last } \\
\text { year. }\end{array}$ & & \\
\hline $\begin{array}{l}\text { In around half of the } \\
\text { programmes, } 50 \text { to } 75 \% \text { of } \\
\text { perpetrators that completed } \\
\text { the programme: The attrition } \\
\text { rate is therefore about } 50 \% \\
\text { to } 25 \% \text { of the attendees }\end{array}$ & $\begin{array}{l}\text { Finland, Sweden, } \\
\text { Denmark and the } \\
\text { Faroe Islands: some } \\
\text { programmes have } \\
\text { more than } 75 \% \text { of } \\
\text { perpetrators } \\
\text { completing the } \\
\text { programme }\end{array}$ & & $\begin{array}{l}\text { Attrition rates, as } \\
\text { proposed by Adams } \\
\text { ( } 2003 \text { ), can be } \\
\text { considered as in the } \\
\text { common range (from } \\
25 \% \text { to } 65 \% \text { ). } \\
\text { Measures should be } \\
\text { taken to maximize } \\
\text { completion rates (i.e. } \\
\text { by constantly } \\
\text { monitoring } \\
\text { perpetrators' } \\
\text { motivation to } \\
\text { complete treatment). }\end{array}$ \\
\hline
\end{tabular}


NATIONAL INSTITUTE

FOR HEALTH AND WELFARE

norden

Section E: Content of Work

\begin{tabular}{|l|l|l|l|l|l|}
\hline $\begin{array}{l}\text { Dimension } \\
\text { s of the } \\
\text { Questionna } \\
\text { ire }\end{array}$ & $\begin{array}{l}\text { Shortcomings and } \\
\text { advantages of Nordic } \\
\text { countries/territories }\end{array}$ & $\begin{array}{l}\text { Specificities in a } \\
\text { Nordic } \\
\text { country/territory }\end{array}$ & $\begin{array}{l}\text { Leading Nordic } \\
\text { country/territory }\end{array}$ & $\begin{array}{l}\text { Comparison } \\
\text { with Europe } \\
\text { (study by } \\
\text { Geldschläger } \\
\text { and } \\
\text { colleagues, } \\
\text { 2014) }\end{array}$ & $\begin{array}{l}\text { Accomplishment of } \\
\text { European Standards } \\
\text { and Future } \\
\text { Recommendations }\end{array}$ \\
\hline $\begin{array}{l}\text { E. Content } \\
\text { of work }\end{array}$ & $\begin{array}{l}\text { Most often mentioned main } \\
\text { goals of the programmes } \\
\text { were: 'ending violence', } \\
\text { 'taking responsibility', } \\
\text { 'ensuring safety'. Some } \\
\text { other aspects also mentioned } \\
\text { included: developing } \\
\text { perpetrator's 'emotional } \\
\text { self-regulation and } \\
\text { communication skills', } \\
\text { 'understanding of violent } \\
\text { acts and psychological } \\
\text { causes', 'reducing damage } \\
\text { for victims', and developing } \\
\text { 'parenting skills'. }\end{array}$ & & & & $\begin{array}{l}\text { Programmes in the } \\
\text { Nordic } \\
\text { countries/territories } \\
\text { work in line with the } \\
\text { main goals referred to } \\
\text { in the Istanbul } \\
\text { Convention and in } \\
\text { the European } \\
\text { standards: ensuring } \\
\text { safety, holding } \\
\text { perpetrators } \\
\text { accountable, include } \\
\text { the perspective of } \\
\text { children (parenting } \\
\text { skills) and helping } \\
\text { perpetrators } \\
\text { understand the } \\
\text { impacts and } \\
\text { consequences of } \\
\text { violence. }\end{array}$ \\
\hline
\end{tabular}


Table

NATIONAL INSTITUTE

FOR HEALTH AND WELFARE

Q norden

Section F: Partner Contact

\begin{tabular}{|c|c|c|c|c|c|}
\hline $\begin{array}{l}\text { Dimension } \\
\text { s of the } \\
\text { Questionna } \\
\text { ire }\end{array}$ & $\begin{array}{l}\text { Shortcomings and } \\
\text { advantages of Nordic } \\
\text { countries/territories }\end{array}$ & $\begin{array}{l}\text { Specificities in a } \\
\text { Nordic } \\
\text { country/territory }\end{array}$ & $\begin{array}{l}\text { Leading Nordic } \\
\text { country/territory }\end{array}$ & $\begin{array}{l}\text { Comparison } \\
\text { with Europe } \\
\text { (study by } \\
\text { Geldschläger } \\
\text { and } \\
\text { colleagues, } \\
\text { 2014) }\end{array}$ & $\begin{array}{l}\text { Accomplishment of } \\
\text { European Standards } \\
\text { and Future } \\
\text { Recommendations }\end{array}$ \\
\hline \multirow[t]{4}{*}{$\begin{array}{l}\text { F. Partner } \\
\text { Contact }\end{array}$} & $\begin{array}{l}\text { About one in five } \\
\text { programmes (19\%) reported } \\
\text { not contacting the (ex-) } \\
\text { partner }\end{array}$ & $\begin{array}{l}\text { In Finland and } \\
\text { Denmark around a } \\
\text { third of the } \\
\text { programmes did not } \\
\text { contact the partner, } \\
\text { while in Sweden } \\
\text { just one service did } \\
\text { not, and in the } \\
\text { Faroe Islands the } \\
\text { only service } \\
\text { provider did not } \\
\text { contact the (ex-) } \\
\text { partner. }\end{array}$ & $\begin{array}{l}\text { In Norway, Iceland, } \\
\text { Alland, and } \\
\text { Greenland, all the } \\
\text { service providers } \\
\text { reported contacting } \\
\text { the (ex-) partner }\end{array}$ & $\begin{array}{l}\text { In the EU } \\
\text { over a third } \\
\text { of the } \\
\text { programmes } \\
\text { do not } \\
\text { contact the } \\
\text { (ex-) } \\
\text { partners }\end{array}$ & $\begin{array}{l}\text { partner should be } \\
\text { contacted }\end{array}$ \\
\hline & $\begin{array}{l}\text { Mostly contact the current } \\
\text { partner and ex-partner, with } \\
\text { just } 17 \% \text { contacting the new } \\
\text { partner (as a potential } \\
\text { victim). }\end{array}$ & & $\begin{array}{l}\text { The new partner (as } \\
\text { a potential victim) } \\
\text { was contacted in } \\
\text { Denmark }(\mathrm{n}=2 \text {; } \\
100 \%) \text {, Sweden } \\
(\mathrm{n}=3 ; 27.2 \%) \text {, and } \\
\text { Finland }(\mathrm{n}=1 \text {; } \\
12.5 \%) \\
\end{array}$ & $\begin{array}{l}\text { In the EU } \\
\text { half of them } \\
\text { contacted the } \\
\text { new partners } \\
\text { as potential } \\
\text { victims }\end{array}$ & \\
\hline & $\begin{array}{l}\text { The (ex-) partner was mostly } \\
\text { contacted at the beginning of } \\
\text { the programme, and just } \\
\text { around half of the } \\
\text { programmes contacted } \\
\text { him/her in the course of } \\
\text { work and/or at the end of it }\end{array}$ & $\begin{array}{l}\text { Finland, Denmark, } \\
\text { and Sweden had } \\
\text { some service } \\
\text { providers who } \\
\text { contacted the } \\
\text { partner at the three } \\
\text { different points. } \\
\text { Aland and Iceland } \\
\text { made contact only } \\
\text { at the beginning } \\
\text { and end }\end{array}$ & $\begin{array}{l}\text { In Norway, all } \\
\text { service providers } \\
\text { contacted the } \\
\text { partner at the } \\
\text { beginning, in the } \\
\text { course of the } \\
\text { programme, and at } \\
\text { the end (all but one } \\
\text { at the end). } \\
\text { Denmark and } \\
\text { Finland had one } \\
\text { service provider } \\
\text { contacting the } \\
\text { partner after 1 year } \\
\text { finishing the } \\
\text { program and after } 2 \\
\text { respectively. }\end{array}$ & & $\begin{array}{l}\text { Finally, partner } \\
\text { contact should also } \\
\text { be done during the } \\
\text { treatment and at the } \\
\text { end of it. }\end{array}$ \\
\hline & $\begin{array}{l}\text { More than } 70 \% \text { of the } \\
\text { programmes reported that } \\
\text { the purpose of contact with } \\
\text { the (ex-) partner was: 'to } \\
\text { share information about } \\
\text { specific victim services, 'to } \\
\text { share information about the } \\
\text { programme and its content', } \\
\text { and 'to know about the }\end{array}$ & $\begin{array}{l}\text { Finland, Denmark, } \\
\text { and Sweden report } \\
\text { some service } \\
\text { providers that do } \\
\text { not share this } \\
\text { information. }\end{array}$ & $\begin{array}{l}\text { Norway is the } \\
\text { country were the } \\
\text { programmes } \\
\text { reported sharing the } \\
\text { most kinds of } \\
\text { information, } \\
\text { followed by } \\
\text { Sweden. } \\
\text { Informing about } \\
\end{array}$ & & $\begin{array}{l}\text { 'safety, security, and } \\
\text { human dignity': } \\
\text { programmes should } \\
\text { ensure that (ex-) } \\
\text { partner is informed } \\
\text { about the goals and } \\
\text { content of the } \\
\text { programmes, its } \\
\text { limitations, and how }\end{array}$ \\
\hline
\end{tabular}

www.thl.fi

Terveyden ja hyvinvoinnin laitos - Institutet för hälsa och välfärd • National Institute for Health and Welfare

Mannerheiminti 166, Helsinki Finland PL/PB/PO. Box 30, Fl 00271 Helsinki, puh/tel +35829 5246000 
Table

NATIONAL INSTITUTE

\section{enorden}

\begin{tabular}{|c|c|c|c|c|}
\hline $\begin{array}{l}\text { partner experience of } \\
\text { violence'. Surprisingly only } \\
\text { around a third of the } \\
\text { programmes reported } \\
\text { contacting the partner to } \\
\text { inform him/her about legal } \\
\text { options like barring or } \\
\text { protection orders or about } \\
\text { specific working methods } \\
\text { (e.g. time out). Most of the } \\
\text { programmes ( } 83 \% \text { ) informed } \\
\text { the partner in crisis } \\
\text { situations, but still some } \\
\text { reporting not contact } \\
\text { him/her in these } \\
\text { circumstances. }\end{array}$ & & $\begin{array}{l}\text { legal options was } \\
\text { done only by } \\
\text { Sweden }(\mathrm{n}=1) \text { and } \\
\text { Norway }(100 \%) \text {, } \\
\text { while limitations of } \\
\text { the program where } \\
\text { shared in Iceland, } \\
\text { Sweden (around } \\
50 \%) \text {, Norway } \\
(100 \%) \text {. }\end{array}$ & & $\begin{array}{l}\text { the partner can use } \\
\text { his/her attendance to } \\
\text { manipulate or control } \\
\text { him/her. Still about } \\
\text { one third of the } \\
\text { programmes in the } \\
\text { Nordic } \\
\text { countries/territories } \\
\text { do not share } \\
\text { information about the } \\
\text { programme, and } \\
\text { around half of the } \\
\text { programmes do not } \\
\text { share information } \\
\text { about specific work } \\
\text { methods and } \\
\text { limitations of the } \\
\text { programmes. }\end{array}$ \\
\hline $\begin{array}{l}\text { Service for the partner was } \\
\text { not offered in about } 10 \% \text { of } \\
\text { the programmes. }\end{array}$ & & $\begin{array}{l}\text { In Finland, } \\
\text { Denmark and } \\
\text { Norway all the } \\
\text { programmes } \\
\text { reported offering } \\
\text { support services to } \\
\text { the partner } \\
\text { (provided by either } \\
\text { their organisations } \\
\text { or by a partner } \\
\text { organization), } \\
\text { whereas in Norway } \\
\text { and Denmark all } \\
\text { the programmes } \\
\text { providing support } \\
\text { were by their } \\
\text { organization. }\end{array}$ & $\begin{array}{l}\text { In the EU, } \\
\text { almost a } \\
\text { third did not } \\
\text { include a } \\
\text { support } \\
\text { service for } \\
\text { the (ex-) } \\
\text { partner. }\end{array}$ & $\begin{array}{l}\text { 'safety, security, and } \\
\text { human dignity' } \\
\text { programmes should } \\
\text { offer (ex-) partners } \\
\text { both group and } \\
\text { individual support }\end{array}$ \\
\hline $\begin{array}{l}\text { Most of the programmes } \\
\text { (more than } 80 \% \text { ) that offered } \\
\text { support offered individual } \\
\text { work, risk assessment and } \\
\text { safety planning and group } \\
\text { work. }\end{array}$ & & $\begin{array}{l}\text { Proactive contacts } \\
\text { (initiated by the } \\
\text { support service) } \\
\text { were present only } \\
\text { in Finland (around } \\
\text { half), Denmark } \\
(25 \%) \text { and Sweden } \\
(21 \%) \text {. Regular } \\
\text { support during the } \\
\text { programme } \\
\text { participation of } \\
\text { perpetrator was } \\
\text { only present in } \\
\text { Finland (around } \\
\text { half), Denmark } \\
\text { (50\%) and Sweden } \\
\text { (around a third). } \\
\end{array}$ & & \\
\hline $\begin{array}{l}\text { Very few programmes } \\
(8.7 \%) \text { reported not having } \\
\text { coordination with victim } \\
\text { support service, nearly half }\end{array}$ & $\begin{array}{l}\text { Finland and } \\
\text { Denmark one } \\
\text { service provider } \\
\text { that did not }\end{array}$ & $\begin{array}{l}\text { Norway all the } \\
\text { programmes } \\
\text { coordinate with it. }\end{array}$ & & $\begin{array}{l}\text { Coordination with } \\
\text { victim services } \\
\text { should be done }\end{array}$ \\
\hline
\end{tabular}


Table

NATIONAL INSTITUTE

FOR HEALTH AND WELFARE

Enordon

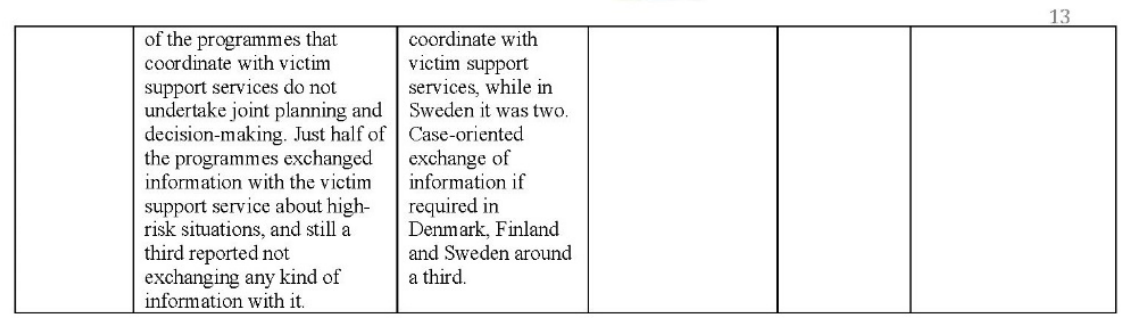


Table

NATIONAL INSTITUTE

FOR HEALTH AND WELFARE

Q norden

Section G: Quality assurance/ documentation / evaluation

\begin{tabular}{|c|c|c|c|c|c|}
\hline $\begin{array}{l}\text { Dimension } \\
\text { s of the } \\
\text { Questionna } \\
\text { ire }\end{array}$ & $\begin{array}{l}\text { Shortcomings and advantages of } \\
\text { Nordic countries/ternitories }\end{array}$ & $\begin{array}{l}\text { Specificities in } \\
\text { a Nordic } \\
\text { country/ternito } \\
\text { ry }\end{array}$ & $\begin{array}{l}\text { Leading Nordic } \\
\text { country/temitory }\end{array}$ & $\begin{array}{l}\text { Comparison } \\
\text { with Europe } \\
\text { (study by } \\
\text { Geldschläger } \\
\text { and } \\
\text { colleagues, } \\
2014 \text { ) } \\
\end{array}$ & $\begin{array}{l}\text { Accomplishment of } \\
\text { European Standards } \\
\text { and Future } \\
\text { Recommendations }\end{array}$ \\
\hline \multirow[t]{4}{*}{$\begin{array}{l}\text { G. Quality } \\
\text { assurance/ } \\
\text { documenta } \\
\text { tion/evalua } \\
\text { tion }\end{array}$} & $\begin{array}{l}\text { Work is documented, through } \\
\text { annual statistics, activity reports } \\
\text { or standardized social statistics } \\
\text { (around } 75 \%-80 \% \text { respectively) }\end{array}$ & & $\begin{array}{l}\text { In the 'others' } \\
\text { section, in Finland } \\
\text { one service provider } \\
\text { reported using a } \\
\text { standardized } \\
\text { questionnaire during } \\
\text { the process. Sweden } \\
\text { reported one } \\
\text { programme (6\%) } \\
\text { which used } \\
\text { interviews with } \\
\text { partner/ex-partner at } \\
\text { the end of the } \\
\text { treatment. }\end{array}$ & $\begin{array}{l}\text { In Europe } \\
\text { (around } \\
65 \% \text { ). }\end{array}$ & \\
\hline & $\begin{array}{l}\text { Still one third of the } \\
\text { programmes do not measure } \\
\text { outcome }\end{array}$ & $\begin{array}{l}\text { Sweden, and } \\
\text { Denmark } \\
\text { reported half } \\
\text { of the } \\
\text { programmes } \\
\text { that reported } \\
\text { not measuring } \\
\text { outcomes }\end{array}$ & $\begin{array}{l}\text { In Iceland and the } \\
\text { Faroe Islands the } \\
\text { only service provider } \\
\text { in each country } \\
\text { reported measuring } \\
\text { outcomes. In Norway } \\
\text { and Finland all the } \\
\text { service providers } \\
\text { reported that they } \\
\text { measured outcomes. }\end{array}$ & $\begin{array}{l}\text { In the EU } \\
\text { almost } 20 \% \\
\text { of the } \\
\text { programmes } \\
\text { do not } \\
\text { measure the } \\
\text { outcomes of } \\
\text { their work }\end{array}$ & \\
\hline & $\begin{array}{l}\text { Nearly a third do not measure } \\
\text { outcomes at the end of the } \\
\text { programme. } \\
\text { Around } 60 \% \text { measure outcomes } \\
\text { at the follow-up (most often at } \\
\text { 12). }\end{array}$ & $\begin{array}{l}\text { Only Iceland } \\
\text { does not } \\
\text { measure } \\
\text { outcomes at } \\
\text { any follow-up }\end{array}$ & & $\begin{array}{l}\text { Around } 60 \% \\
\text { measure } \\
\text { outcomes at } \\
\text { follow-up in } \\
\text { both regions } \\
\text { (mainly in } \\
\text { the first six } \\
\text { months). }\end{array}$ & $\begin{array}{l}\text { Outcome should be } \\
\text { measured at follow- } \\
\text { up at least after } 6 \\
\text { months, this seems to } \\
\text { been achieved in the } \\
\text { Nordic } \\
\text { countries/territories }\end{array}$ \\
\hline & $\begin{array}{l}\text { Main outcomes measured: 'non- } \\
\text { violence and/or decrease of } \\
\text { violence ( }(94.6 \%) \text { ', } \\
\text { 'improvement of client's quality } \\
\text { of life }(83.8 \%) \text { ', and } \\
\text { 'improvement of client's } \\
\text { communication skills and } \\
\text { conflict resolution skills } \\
(70.3 \%) \text { '. The items referred to } \\
\text { the partmer received less } \\
\text { emphasis: 'improvement of } \\
\text { partner's feeling of safety } \\
(67.57 \%) \text { ', 'improvement of } \\
\text { partner's quality of life } \\
(29.73 \%) \text { ', and 'improvement of }\end{array}$ & $\begin{array}{l}\text { Faroe Islands } \\
\text { is the only } \\
\text { territory that } \\
\text { did not take } \\
\text { into account } \\
\text { any partmer } \\
\text { measures. }\end{array}$ & $\begin{array}{l}\text { Finland, and Norway, } \\
\text { and Denmark had } \\
\text { more programmes } \\
\text { that use partmer } \\
\text { measure (more than } \\
50 \% \text { ). Iceland too, } \\
\text { but just in one } \\
\text { programme. } \\
\text { In the section 'others' } \\
\text { just in Sweden: one } \\
\text { programme reported } \\
\text { measuring the } \\
\text { improvement of the } \\
\text { children's feelings of } \\
\text { safety. }\end{array}$ & $\begin{array}{l}\text { Similar } \\
\text { dimensions } \\
\text { to measure } \\
\text { outcome, } \\
\text { however in } \\
\text { the EU it } \\
\text { was } \\
\text { important to } \\
\text { measure } \\
\text { 'attitudes } \\
\text { and beliefs } \\
\text { that support } \\
\text { violence', } \\
\text { while in } \\
\text { Nordic }\end{array}$ & $\begin{array}{l}\text { Measures from the } \\
\text { partner should have } \\
\text { more relevance and } \\
\text { change should be } \\
\text { measured } \\
\text { individually and } \\
\text { qualitatively, } \\
\text { analysing variables } \\
\text { that can be effected: } \\
\text { for example, } \\
\text { perceived severity, } \\
\text { level of } \\
\text { responsibility, etc. }\end{array}$ \\
\hline
\end{tabular}

www.thl.fi

Terveyden ja hyvinvoinnin laitos $~ *$ Institutet för halsa och valfard $~ *$ National Institute for Health and Welfare

Mannerheimintie 166, Helsinki, Finland PL/PB/P.O. Box 30, FI-00271 Helsinki, puh/tel + 358295246000 
Table

\begin{tabular}{|c|c|c|c|c|}
\hline $\begin{array}{l}\text { other aspects of the relationship } \\
\text { (e.g. communication) } \\
(10.81 \%)^{\prime} \text {. }\end{array}$ & & & $\begin{array}{l}\text { countries/terr } \\
\text { itories, it } \\
\text { was } \\
\text { 'improveme } \\
\text { nt of client's } \\
\text { quality of } \\
\text { life and } \\
\text { partners' } \\
\text { feelings of } \\
\text { safety'. Less } \\
\text { than half of } \\
\text { the } \\
\text { programmes } \\
\text { measure } \\
\text { outcomes } \\
\text { related to the } \\
\text { (ex-) } \\
\text { partmers, } \\
\text { which was } \\
\text { similar } \\
\text { between the } \\
\text { EU and } \\
\text { Nordic } \\
\text { countries/terr } \\
\text { itories }\end{array}$ & \\
\hline $\begin{array}{l}\text { The most often used instruments } \\
\text { to measure outcome: client's } \\
\text { self-assessment either by } \\
\text { interview }(78.95 \%) \text {, or by } \\
\text { questionnaire }(81.58 \%) \text {. Also, } \\
\text { measures from the partner had } \\
\text { some relevance: partner's } \\
\text { assessment either by interview } \\
(47.37 \%) \text {, or by questionnaire or } \\
\text { inventory ( } 44.74 \%) \text {. There was } \\
\text { no programme that reported } \\
\text { using official reports (police, } \\
\text { court etc.) as an outcome } \\
\text { measure. } \\
\text { In general, measures related to } \\
\text { the partner (around } 50 \%) \text { have } \\
\text { more relevance than the } \\
\text { facilitator-related measures (a } \\
\text { third) }\end{array}$ & $\begin{array}{l}\text { Faroe Islands } \\
\text { and Greenland } \\
\text { did not take } \\
\text { into account } \\
\text { partner-related } \\
\text { measures. }\end{array}$ & $\begin{array}{l}\text { The partner's } \\
\text { instruments were } \\
\text { especially relevant in } \\
\text { (at least } 50 \% \text { of the } \\
\text { programmes) Iceland, } \\
\text { Denmark, Norway. } \\
\text { Finland and Sweden } \\
\text { also took them into } \\
\text { account but in about } \\
\text { a third of } \\
\text { programmes and one } \\
\text { programme } \\
\text { respectively. }\end{array}$ & $\begin{array}{l}\text { The method } \\
\text { the } \\
\text { programmes } \\
\text { used to } \\
\text { measure } \\
\text { outcomes } \\
\text { were } \\
\text { reviewing } \\
\text { their notes in } \\
\text { the EU }\end{array}$ & $\begin{array}{l}\text { Official reports } \\
\text { should be included as } \\
\text { measures to } \\
\text { triangulate data, } \\
\text { together with the } \\
\text { client's self-reports, } \\
\text { for evaluation. }\end{array}$ \\
\hline $\begin{array}{l}\text { Nearly a third of the } \\
\text { programmes did not have an } \\
\text { internal evaluation of their } \\
\text { work, whereas half did not have } \\
\text { an external evaluation. }\end{array}$ & & $\begin{array}{l}\text { Iceland, Norway, and } \\
\text { Finland had some } \\
\text { programmes with } \\
\text { external evaluation, } \\
\text { through collaboration } \\
\text { with research projects } \\
\text { from universities }\end{array}$ & & \\
\hline
\end{tabular}


Nordic Council of Ministers

Ved Stranden 18

DK-1061 Copenhagen K

www.norden.org

\section{Nordic Countries Overview of Work with Perpetrators of Intimate Partner Violence}

The aim of the Nu Räcker Det was to map out the models used in the Nordic countries to help the perpetrators of IPV to end violence. The project questionnaire was filled in by the service providers. The number of invited programmes was 68 , and the response rate was around $80 \%$. Results indicate that still some services are not free of charge and are not equally distributed geographically. In terms of safety, although most programmes contact the (ex-) partner at the beginning of the treatment, still half of the programmes do not contact the (ex-) partner during the treatment or at the end of it, moreover nearly half of the programmes do not use any risk assessment instrument. Outcome is measured by most of the programmes however partner and official reports should also be included. Finally, those results are compared and discussed in light of the European context. 